\title{
An overview of the HIBISCUS campaign
}

\author{
J.-P. Pommereau ${ }^{1}$, A. Garnier ${ }^{1}$, G. Held ${ }^{2}$, A. M. Gomes ${ }^{2}$, F. Goutail ${ }^{1}$, G. Durry ${ }^{1, *}$, F. Borchi ${ }^{1}$, A. Hauchecorne ${ }^{1}$,

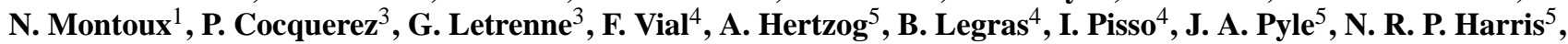 \\ R. L. Jones ${ }^{5}$, A. D. Robinson ${ }^{5}$, G. Hansford ${ }^{5}$, L. Eden $^{5}$, T. Gardiner ${ }^{6}$, N. Swann ${ }^{6}$, B. Knudsen ${ }^{7}$, N. Larsen ${ }^{7}$, \\ J. K. Nielsen ${ }^{7}$, T. Christensen ${ }^{7}$, F. Cairo ${ }^{8}$, F. Fierli ${ }^{8}$, M. Pirre ${ }^{9}$, V. Marécal $^{9}$, N. Huret ${ }^{9}$, E. D. Rivière ${ }^{9}{ }^{*}$, H. Coe $^{10}$, \\ D. Grosvenor ${ }^{10}$, K. Edvarsen ${ }^{11}$, G. Di Donfrancesco ${ }^{12}$, P. Ricaud ${ }^{13}$, J.-J. Berthelier ${ }^{14}$, M. Godefroy ${ }^{14}$, E. Seran ${ }^{14}$, \\ K. Longo ${ }^{15}$, and S. Freitas ${ }^{15}$ \\ ${ }^{1}$ CNRS-Service d'Aéronomie (SA), now: CNRS-LATMOS, Université de Versailles, France \\ ${ }^{2}$ Instituto de Pesquisas Meteorológicas, UNESP, Bauru, Brazil \\ ${ }^{3}$ Centre National d'Etudes Spatiales (CNES), Toulouse, France \\ ${ }^{4}$ CNRS-Laboratoire de Météorologie Dynamique (LMD), Palaiseau, France \\ ${ }^{5}$ University of Cambridge (UCAM), Dept. of Chemistry, Cambridge, UK \\ ${ }^{6}$ National Physical Laboratory (NPL), Teddington, UK \\ ${ }^{7}$ Danish Meteorological Institute, Copenhagen, Denmark \\ ${ }^{8}$ Consiglio Nazionale delle Ricerche, Istituto di Scienze dell' Atmosfera e del Clima (CNR-ISAC), Roma, Italy \\ ${ }^{9}$ CNRS-Laboratoire de Physique et Chime de l'Environnement (LPCE), Orléans, France \\ ${ }^{10}$ University of Manchester, Manchester, UK \\ ${ }^{11}$ Norwegian Institute for Air Research (NILU), Kjeller, Norway \\ ${ }^{12}$ Agenzia nazionale per le nuove tecnologie, l'energia e lo sviluppo economico sostenibile, (ENEA), Roma, Italy \\ ${ }^{13}$ CNRS Laboratoire d'Aérologie (LA), Toulouse, France \\ ${ }^{14}$ Centre d'Etude des Environnements Terrestre et Planétaires (CETP), now: CNRS-LATMOS, Université de Versailles \\ St. Maur, France \\ ${ }^{15}$ Centro de Previsão de Tempo e Estudos Climàticos (CPTEC), Cachoeira Paulista, Brazil \\ *now at: Université de Reims Champagne-Ardennes, CNRS Groupe de Spectrométrie Moléculaire et Atmosphérique \\ (GSMA), France
}

Received: 19 January 2007 - Published in Atmos. Chem. Phys. Discuss.: 21 February 2007

Revised: 14 February 2011 - Accepted: 25 February 2011 - Published: 15 March 2011

\begin{abstract}
The EU HIBISCUS project consisted of a series of field campaigns during the intense convective summers in 2001, 2003 and 2004 in the State of São Paulo in Brazil. Its objective was to investigate the impact of deep convection on the Tropical Tropopause Layer (TTL) and the lower stratosphere by providing a new set of observational data on meteorology, tracers of horizontal and vertical transport, water vapour, clouds, and chemistry in the tropical Upper Troposphere/Lower Stratosphere (UT/LS). This was achieved using short duration research balloons to study local phenomena associated with convection over land, and long-duration
\end{abstract}

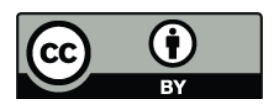

Correspondence to: J.-P. Pommereau (jean-pierre.pommereau@ @ latmos.ipsl.fr) balloons circumnavigating the globe to study the contrast between land and oceans.

Analyses of observations of short-lived tracers, ozone and ice particles show strong episodic local updraughts of cold air across the lapse rate tropopause up to 18 or $19 \mathrm{~km}(420$ $440 \mathrm{~K})$ in the lower stratosphere by overshooting towers. The long duration balloon and satellite measurements reveal a contrast between the composition of the lower stratosphere over land and oceanic areas, suggesting significant global impact of such events. The overshoots are shown to be well captured by non-hydrostatic meso-scale Cloud Resolving Models indicating vertical velocities of $50-60 \mathrm{~m} \mathrm{~s}^{-1}$ at the top of the Neutral Buoyancy Level (NBL) at around $14 \mathrm{~km}$, but, in contrast, are poorly represented by global Chemistry-Transport Models (CTM) forced by Numerical

Published by Copernicus Publications on behalf of the European Geosciences Union. 
Weather Forecast Models (NWP) underestimating the overshooting process. Finally, the data collected by the HIBISCUS balloons have allowed a thorough evaluation of temperature NWP analyses and reanalyses, as well as satellite ozone, nitrogen oxide, water vapour and bromine oxide measurements in the tropics.

\section{Introduction}

The tropical Upper Troposphere/Lower Stratosphere (UT/LS) is a key region for both stratospheric ozone depletion and climate. It is the source region of ozone-depleting substances, like organic chlorine, bromine and possibly iodine, as well as long-lived source gases such as nitrous oxide, methane, which after oxidation at high altitude and transport at mid-and high latitude by the Brewer-Dobson circulation are controlling ozone chemistry. It is also the region controlling the water vapour content of air entering the stratosphere, partly responsible for the cooling of the stratosphere. The tropical UT/LS is the altitude level where ozone, an efficient greenhouse gas at this altitude, is found to be highly variable for several possible reasons: (a) its convective uplift from the surface; (b) its formation by photochemical precursors; (c) the quasi-horizontal exchange with the lowermost stratosphere; and (d) because the region is the most exposed to $\mathrm{NO}_{\mathrm{x}}$ production by lightning within thunderstorms.

However, there are a number of unresolved issues in the tropical UT/LS, such as the impact of local convective overshooting on troposphere-to-stratosphere transport (TST), on the hydration/dehydration processes of air entering the stratosphere, and on the concentration of short-lived chemical species in the UTLS, which is highly dependent on the speed of their lofting. Based on the assumption that the largest vertical motion into the stratosphere occurs where the temperature of the tropopause is the lowest, Newell and Gould-Stewart (1981) suggested the idea of a limited region of entry of dehydrated tropospheric air into the stratosphere, namely the "Stratospheric Fountain" above Indonesian Islands and Micronesia, also called "the Maritime Continent". A remarkable characteristic of convection in this region, and to some extent in the entire tropical belt, is its large intraseasonal variability associated with the phase of the MaddenJulian oscillation (MJO) (Wheeler et al., 2009 and references therein). However studies from a number of years (e.g., Danielsen (1993) from ER-2 observations during the STEP mission over Northern Australia in 1987, and analyses of radiosondes or radar observation in Darwin and Samoa in the Southern Pacific, e.g., Folkins et al., 1999; Gettelman et al., 2002; May and Ballinger, 2007), maritime convection is on average less intense and hardly penetrates the stratosphere compared to continental systems, although large overshoots can occur above tropical cyclones (Ebert and Holland, 1993; Tuck et al., 1997).

However, such systems are generally thought rare and thus unimportant at the global scale. On average, convection reaches only the upper troposphere where a barrier to vertical mixing could be generally observed around $14 \mathrm{~km}$, the bottom of the so-called Tropical Tropopause Layer (TTL) (Folkins et al., 1999). The proposal thus made by Sherwood and Dessler (2000) for troposphere-stratosphere exchange is a two-step process: a vigorous convective lifting up to the bottom of the TTL followed by a slow ascent after radiative heating in the TTL, a process known as the "mixing layer" hypothesis. A revised concept of TTL and a thorough description of the vertical transport process within the layer are provided by Fueglistaler et al. (2009), who noted in their conclusion that "the effect of overshooting convection on the heat balance of the TTL is still a major unknown".

Before HIBISCUS, most observations had been carried out over oceanic areas because of the many problems in making in-situ aircraft or balloon observations next to deep convection over land. In addition, the frequency of occurrence of stratosphere-penetrating land mesoscale systems was hard to assess. It is only recently that space-borne precipitation radar (PR) and visible-IR imager (VIIRS) observations aboard the NASA Tropical Rainfall Measurements Mission satellite (TRMM) have shown that land convective systems, developing in the afternoon, reached higher altitudes than maritime systems (Nesbitt et al., 2000; Alcala and Dessler, 2002; Nowicky and Merchant, 2004; Liu and Zipser, 2005).

Within this context, the objectives of HIBISCUS were to provide a set of new observational data on meteorology, tracers of horizontal and vertical transport, water vapour, clouds, and chemistry in the tropical UT/LS from balloon observations at local scale within a subtropical convective land area in Brazil, as well as at global scale using circumnavigating long-duration balloons, for studying the contrast between continents and oceans, the representation of temperature and wind in the Numerical Weather Prediction (NWP) models analyses, and the performances of satellite ozone and chemicals measurements in the tropics. This overview describes the background of the project, including the available observational and modelling tools, and highlights the most significant results.

\section{Campaign context}

The campaigns took place in Bauru $\left(22.3^{\circ} \mathrm{S}, 49^{\circ} \mathrm{W}\right)$ in the subtropics, $330 \mathrm{~km}$ west of São Paulo in Brazil during the Southern Hemisphere summers in 2001, 2003 and 2004. Located in the South Atlantic Convergence Zone (Fig. 1), during the Southern Hemisphere summer, it is one of the most intense convective regions on Earth (Liu and Zipser, 2005). The experiment was conducted in collaboration with the Meteorological Research Institute (IPMet) of the São Paulo 


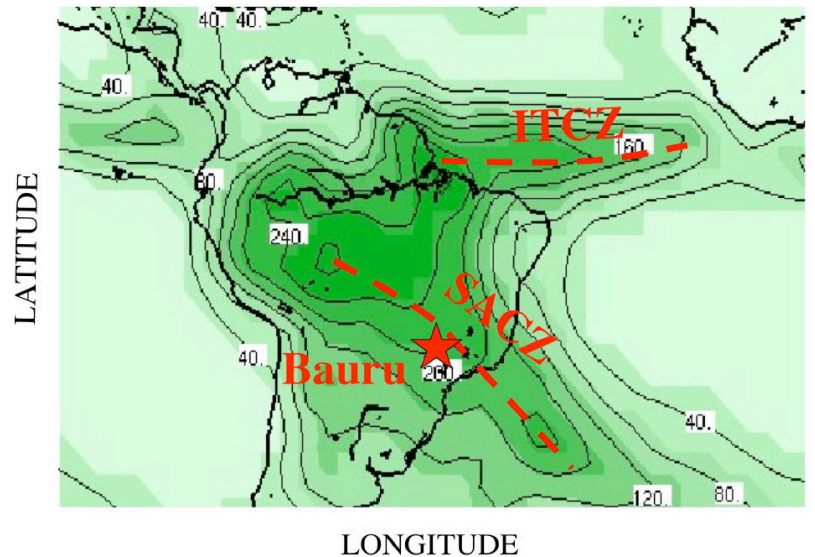

Fig. 1. Precipitation ( $\mathrm{mm}$ ) in South America in January. ITCZ is the Intertropical Convergence Zone near the equator. Bauru $\left(22.3^{\circ} \mathrm{S}\right.$, $49^{\circ} \mathrm{W}$ ) is located in the convectively active region of the South Atlantic Convergence Zone (SACZ) and has a $260 \mathrm{~mm}$ average rainfall during the month.

State University (UNESP). Importantly, Bauru offers a suitable balloon launch area, and crucially, a Doppler radar for thunderstorms monitoring during launch operations.

\subsection{Meteorology}

As shown by the potential vorticity altitude-latitude crosssection and the maps displayed in Figs. 2 and 3, Bauru is located in an area of easterly wind north of the subtropical jet in the lower stratosphere and on the south-east side of the Bolivian upper tropospheric high in a $\mathrm{W}-\mathrm{SW}$ wind regime (see Huntrieser et al., 2007). From Bauru, short-duration balloons can fly west towards accessible areas with safe payload recovery for short-duration balloons and towards the $\mathrm{Pa}$ cific for the long-duration balloons to start their tropical circumnavigation. Even during an episode of maximum northward shift of the sub-tropical barrier, such as on 31 January 2004, shown in Figs. 2 and 3, the UTLS above this region is still tropical in nature. The lapse rate tropopause (LRT, $\mathrm{d} T / \mathrm{d} Z \leq \pm 2{ }^{\circ} \mathrm{C} \mathrm{km}^{-1}$ following WMO definition) is on average at around $16 \mathrm{~km}(370 \mathrm{~K})$, surmounted by a cold point tropopause (CPT) $1.5-2 \mathrm{~km}$ higher. In February 2004, the frequency of days when one or more echo tops was observed above $15 \mathrm{~km}$ was of $58 \%$ (Fig. 4 from Gomes and Held, 2004), displaying a strong daily maximum at around 16:0017:00 local time. The average maximum latitude of echotops was 18 km (Fig. 5 from Pommereau and Held, 2007).

\subsection{Observational context}

The short- and long-duration balloons were operated by the French Centre National d'Etudes Spatiales (CNES). These were complemented by a set of radiosondes, backscatter and ozone-sondes, and ground-based observations (Doppler

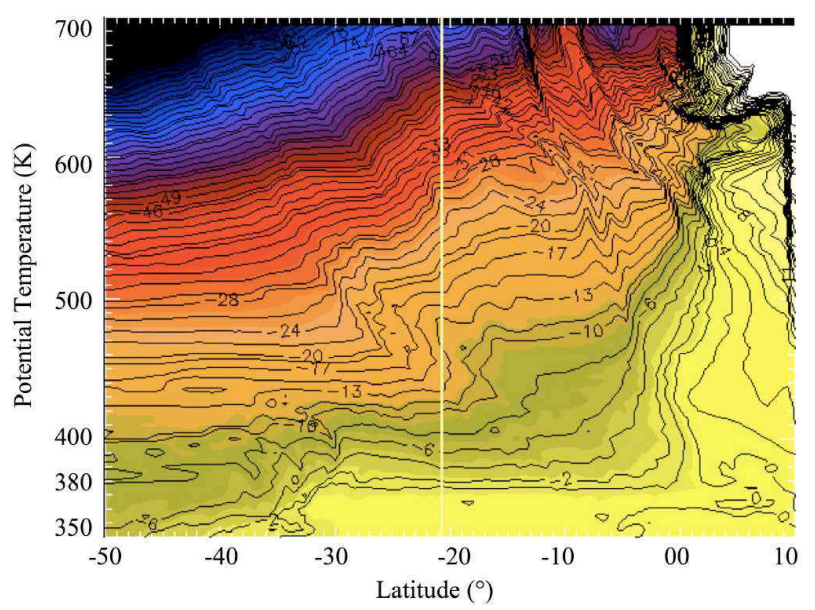

Fig. 2. Meridional cross-section of potential vorticity (pv unit) at $50^{\circ} \mathrm{W}$ on 31 January 2004 , the day of largest northward shift of the sub-tropical barrier during the campaign. The vertical line indicates the latitude of Bauru. In the upper troposphere and the lower stratosphere it is still north of the maximum PV meridional gradient, the location of the sub-tropical jet, in a region of tropopause at $2 \mathrm{PV}$ unit at $380 \mathrm{~K}$, that is still in the Tropical Tropopause Layer.

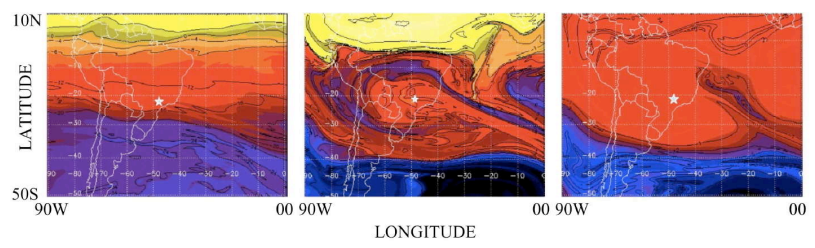

Fig. 3. Potential Vorticity (pv unit) maps on the same day at $475 \mathrm{~K}$ in the stratosphere (left), at $380 \mathrm{~K}$ at the tropopause level (middle), and at $350 \mathrm{~K}$ in the troposphere (right). The location of Bauru is indicated by a white star. At $475 \mathrm{~K}$ in the stratosphere is in a region of easterly wind north of the sub-tropical jet (the region of maximum meridional PV gradient) and at $350 \mathrm{~K}$ in a region of W-SW wind blowing around the South American upper tropospheric high. The tropopause level at $380 \mathrm{~K}$, around $15.5 \mathrm{~km}$, is a level of light wind of maximum mixing between the mid-latitude and the tropics.

radar, lidar, lightning network) provided by IPMet in the frame of a Brazilian collaborative project Tropical Convection and Cirrus Brazil (TroCCiBras) (Held et al., 2007, 2008). There was close collaboration with the European tropical project TROCCINOX (Tropical Convection, Cirrus and Nitrogen Oxides Experiment) (Huntrieser et al., 2007), with the Deutsches Zentrum für Luft- und Raumfahrt (DLR) Falcon aircraft being deployed from a nearby airport. In addition, collaboration was established with the European Space Agency giving access to the data of the Environmental Satellite (ENVISAT) measurements prior to their public release, and with the ODIN Swedish-Canada-Finish-French satellite for reinforced observations over the area during the period. Finally, collaborations were agreed with the US 


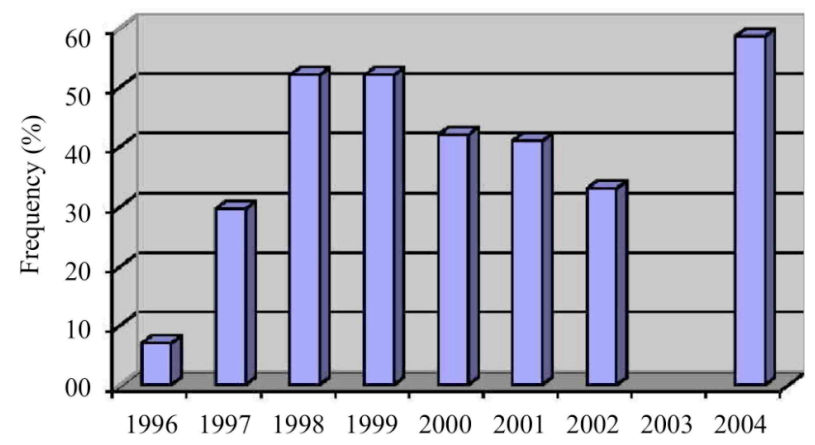

Fig. 4. Frequency of days in February 1996-2004 (no survey in 2003) when one or more echo tops (10 dBZ threshold reflectivity, storm volume $\geq 50 \mathrm{~km}^{3}$ ) was observed above $15 \mathrm{~km}$ altitude within the $240 \mathrm{~km}$ range of the IPMet S-band radar in Bauru (Gomes and Held, 2004). February 2004 was among the most active month among the $8 \mathrm{yr}$ of observation.

National Oceanic and Atmospheric Administration (NOAA) ozonesonde stations of Samoa and Fiji, as well as with the French Reunion Island station for dedicated ascents during the overpass of the long-duration balloons.

The deployment of such a complex experiment at a relatively new facility in a region prone to thunderstorms during the rainy season (only two short-duration flights in 1997, Pommereau et al., 1999) was challenging, especially as it included the deployment of several new instruments and payloads and the use of new balloons designed for slow overnight descents across the TTL. The preparation of the HIBISCUS campaign involved a number of instrument test flights in France as well as in the tropics in 2001-2003. Two preliminary campaigns took place in Bauru during the austral summer 2000-2001 and later in February 2003, whose data, available in the HIBISCUS database, have been also used for scientific purposes.

A decisive advantage was the interest of Brazilian scientists to participate in the project through a number of collaborative observations, as well as in the analysis and interpretation of the data. Under the coordination of IPMet and the umbrella of the TroCCiBras Brazilian project, HIBISCUS and TROCCINOX could develop a mutually beneficial scientific collaboration with a number of Brazilian research institutes.

\section{Balloons and ground-based instrumentation, satellites and modelling tools}

A number of in situ and remote sensing instruments have been flown during HIBISCUS on short- and long-duration platforms. The balloons, their instrumentation, as well as the models used were essentially those developed during the 1990's for investigating polar ozone depletion in the Arctic (Newman et al., 2002), and subsequently adapted for use

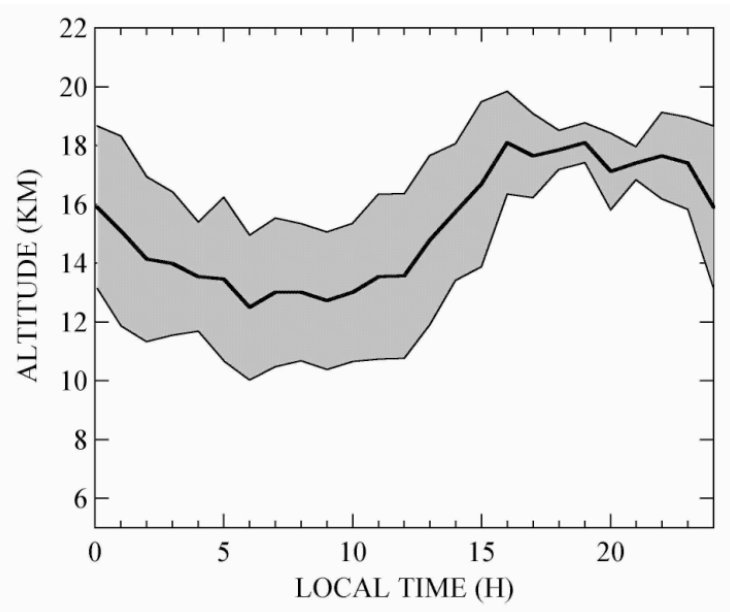

Fig. 5. Diurnal variation of maximum echo-top height average and standard deviation seen by the Bauru radar within its $240 \mathrm{~km}$ range during the high and medium convective days (2800 counts/day average).

in the tropics. Balloon operations and measurements were complemented by several ground-based and satellite observations, and a variety of models. They are briefly described below.

\subsection{Short-duration balloons}

The balloons used for these flights were of three types:

i. small Zodiac stratospheric balloons (SF) of $3000 \mathrm{~m}^{3}$ volume of $25 \mu \mathrm{m}$ material, carrying $150 \mathrm{~kg}$ at $22 \mathrm{~km}$. They were designed to descend slowly after sunset by radiative cooling to allow in situ measurements in the TTL,

ii. Zodiac Light (ZL) of $16 \mu \mathrm{m}$ polyethylene and $10000 \mathrm{~m}^{3}$ volume balloons, carrying $120 \mathrm{~kg}$ for an ascent to $30 \mathrm{~km}$ followed by a short float for $1-2 \mathrm{~h}$ at sunset for solar occultation measurements, and

iii. aerostar plastic balloons of 240 and $1500 \mathrm{~m}^{3}$ volume for soundings with payloads of $10-20 \mathrm{~kg}$.

The list of instruments included:

i. in situ sensors operating during the ascent and the slow night time descent of the balloons: a light weight DIRAC (Determination in situ by Rapid Analytical Chromatography) Gas Chromatograph and a DESCARTES (Détermination et Séparation par Chromatographie lors de l'Analyse des Résultats des Traceurs Echantillonnés dans la Stratosphère) grab sampler of UCAM for tracers and short-lived species, two tuneable diode lasers, a TDLAS (Tuneable Diode Laser) of NPL and the $\mu$ SDLA (micro-Spectrometric Diode 
Laser) of CNRS-SA for water vapour and methane, a surface acoustic wave (SAW) hygrometer and an ozone solid state sensor (O3SSS) of UCAM, a Laser Basckscatter Sonde (LABS) of CNR-ISAC for aerosols, and an electric field probe of CETP;

ii. five remote sensors: a Système d'Analyse par Observation Zenitale (SAOZ) UV-visible spectrometer of CNRS-SA for $\mathrm{O}_{3}$ and $\mathrm{NO}_{2}$ profiles and a UV extended version of the same instrument for $\mathrm{O}_{3}, \mathrm{NO}_{2}, \mathrm{BrO}$ and aerosols profiles by solar occultation during the daytime ascent of the balloon and from float altitude at sunset, a UV radiometer of NILU for daytime photolysis rates retrievals, a downward looking MULID micro-lidar of ENEA and CNR-ISAC for aerosols and clouds vertical profiling, and an optical lightning detector; and,

iii. ozone Electro-Chemical-Cell (ECC) and aerosols backscatter (BKS) sondes.

A short description of each is provided in the Appendix.

\subsection{Long-duration balloons}

Two types of long-duration balloons were used: (i) constant level $8.5 \mathrm{~m}$ or $10 \mathrm{~m}$ diameter spherical $12 \mu \mathrm{m}$ thick Mylar constant altitude super-pressure balloons (SPB) carrying $20 \mathrm{~kg}$ at respectively 18 and $19 \mathrm{~km}$; and (ii) Infra-Red Montgolfier (MIR) balloons of $45000 \mathrm{~m}^{3}$ volume in $15 \mu \mathrm{m}$ aluminized Mylar for the upper part and $12 \mu \mathrm{m}$ transparent polyethylene for the bottom, carrying $60 \mathrm{~kg}$ at $28 \mathrm{~km}$ during daytime and $20-24 \mathrm{~km}$ at night depending on the cloud cover (Pommereau and Hauchecorne, 1979). The payloads carried on each type of balloon were chosen based on their technical maturity with respect to the severe thermal, power, weight and telemetry constraints.

The payload on SBP flights designed by CNRS-LMD, called RUMBA, included a Global Positioning System (GPS) for location $( \pm 10 \mathrm{~m})$ and horizontal wind calculation $\left( \pm 0.01 \mathrm{~m} \mathrm{~s}^{-1}\right)$, a pressure $( \pm 0.6 \mathrm{hPa})$ and two temperature sensors ( $\pm 0.25 \mathrm{~K}$ at night, $0.3 \mathrm{~K}$ during daytime). The measurements were sampled every $15 \mathrm{~min}$ and transmitted via the ARGOS telecommunication system. The temperature sensors were small thermistors, mounted $180^{\circ}$ apart on a 1-m boom, hanging $5 \mathrm{~m}$ below the gondola. Two types of small passenger instruments were mounted: a combination of $\mathrm{O}_{3} \mathrm{SSS}$ and SAW sensors on the balloons flying at $18 \mathrm{~km}$ near the cold point tropopause and a prototype of turbulence sensor designed by CNRS-LMD on those flying at $19 \mathrm{~km}$. The $\mathrm{O}_{3} \mathrm{SSS}$ and SAW were essentially identical to those flown on the short-duration balloons, even though the operational methods were tailored to the constraints of the long-duration flights. The turbulence sensor was made of a micro-accelerometer $\left(10^{-6} \mathrm{~g}\right.$ resolution) sampled at high frequency $(200 \mathrm{~Hz})$ measuring the motion of the gondola induced by atmospheric turbulence. The variance in several spectral bands between 0 and $100 \mathrm{~Hz}$ was transmitted to the ground.

Depending on the flight, the MIRs were carrying one or two payloads: a CNES service gondola controlling the flight (Inmarsat telemetry and remote control) hosting a microlidar, or the service payload and an independent SAOZ payload suspended $40 \mathrm{~m}$ below. The service payloads included a GPS, a pressure sensor and two thermistors, as well as a lightweight (160 g) global IR radiometer of CNRS-SA based on a design proposed Suomi and Kuhn (1958). The nadirlooking MULID micro-lidar was similar to those flown on short duration balloons, but only operated every 15 min during the night for backscatter and depolarization profiles under the balloon. The SAOZ long-duration version was similar to that used on short-duration balloons, but with two important differences: (i) the spectral range extended up to $1000 \mathrm{~nm}$ for the measurement of stratospheric water vapour around 760 and $940 \mathrm{~nm}$; and (ii) onboard spectral analysis was used due to the limitation in the telemetry capacity of the ARGOS system. Results of the analysis only (slant columns and fitting errors) were transmitted, whilst the spectra were stored on board in case of recovery at the end of the flight, which was always the case when the flight ended over a continent. The SAOZ payload was equipped with a GPS, Vaisala RS80 pressure and temperature sensors and two optical detectors respectively nadir- and zenith-viewing for the detection of lightning flashes and at zenith for blue-jets.

\subsection{Ground-based observations and operational modelling}

Ground-based instruments and meteorological products were provided by the TroCCiBras project (Held et al., 2007, 2008), which were essential for operations and interpretation of balloon data:

i. two Doppler S-band Doppler radars at Bauru (BRU) and at Presidente Prudente (PPR) located $240 \mathrm{~km}$ west of Bauru in the direction of the balloon flights were extensively used for balloon flight decisions;

ii. Vaisala RS80 radio-soundings four times per day for a total of 107 soundings;

iii. the Meso-Eta meteorological model of the Centro de Previsão de Tempo e Estudos Climàticos (CPTEC), centred over Bauru and covering the whole State of São Paulo with a $10 \times 10 \mathrm{~km}$ resolution grid run twice a day (00:00 and 12:00 UT) providing 3-hourly forecasts;

iv. daily 3-D back trajectories calculated by the CPTEC Regional Atmospheric Modelling System (RAMS) model used for optimising the flights;

v. meteorological data from the automatic weather station network and those of a Lightning Detection Network (RINDAT) and GOES-E images (available every $30 \mathrm{~min}$ ) was archived in the TROCCIBRAS data base. 
Table 1. Instruments flight tests in 2001.

\begin{tabular}{llll}
\hline Instrument (Institute) & Parameter & ZL1 & ZL2 \\
\hline SAOZ Vis, SA & $\mathrm{O}_{3}, \mathrm{NO}_{2}$ profiles & $\mathrm{X}$ & $\mathrm{X}$ \\
SAOZ UV, SA & $\mathrm{BrO}$ profile & $\mathrm{X}$ & $\mathrm{X}$ \\
SAOZ $\mathrm{H}_{2} \mathrm{O}, \mathrm{SA}$ & $\mathrm{H}_{2} \mathrm{O}$ profile & $\mathrm{X}$ & $\mathrm{X}$ \\
SAW Hygrometer, UCAM & $\mathrm{H}_{2} \mathrm{O}$ & $\mathrm{X}$ & $\mathrm{X}$ \\
SSS Ozone sensor, UCAM & $\mathrm{O}_{3}$ & & \\
Micro-lidar, ENEA / ISAC & Backscatter ratio/ & & \\
& polarization & & \\
&
\end{tabular}

Daily $\mathrm{O}_{3}$ and $\mathrm{NO}_{2}$ columns measurements from a $\mathrm{SAOZ}$ ground-based spectrometer deployed in Bauru since 1995 in the frame of the Network for Detection of Atmospheric Composition Change (NDACC) were also available.

\subsection{Modelling tools}

The interpretation of the large amount of observations collected during the experimental period required the use of modelling tools of different types. Meteorological information included the European Center for Medium range Weather Forecasting (ECMWF) operational analyses (Rabier et al., 2000), the ECMWF ERA40 reanalysis (Simmons and Gibson, 2000), and the NCEP/NCAR re-analyses (Kistler et al., 2000); while atmospheric models included the Modélisation Isentrope du transport Méso-échelle de l'Ozone Stratosphérique par Advection (MIMOSA) highresolution contour advection model (Hauchecorne et al., 2002), the p-TOMCAT CTM (O'Connor et al., 2005), the Reactive Processes Ruling the Ozone Budget in the Stratosphere (REPROBUS) CTM (Lefèvre et al., 1994), a mesoscale Regional Atmospheric Modelling System (RAMS) (Pielke et al., 1992) and its Brazilian version (BRAMS) coupled with 3-D back trajectory calculations at mesoscale (Freitas et al., 2000), the Microphysical Photochemical Lagrangian Stratospheric Model of Ozone (MiPLaSMO) Lagrangian photochemical model (Rivière et al., 2003), the Microphysical Cloud Model of the Danish Meteorological Institute, the UK Met Office Large Eddy Model (LEM) Cloud Resolving Model (Shutts and Gray, 1994; Swann 1998), and finally, the radiative transfer model of NILU. Their use in the interpretation of the HIBISCUS is given below.

\section{HIBISCUS field campaigns}

Three deployments took place within the HIBISCUS programme, all from Bauru. The first in November 2000 and February 2001 involved test flights of (a) Infra-Red Montgolfier long-duration balloons never previously flown in the tropics (to which a SAOZ and or micro-lidar payload could be added), and (b) of short-duration balloons to test the operational and the nighttime slow descent procedures. The second deployment in February 2003 was dedicated to the testing of new instruments and the validation of ENVISAT observations in the tropical stratosphere and also involved short and long-duration MIR balloon flights. The final and main HIBISCUS campaign was in January-March 2004 and involved all types of balloons including constant level superpressure (SPB).

\subsection{MIR and ZL balloons test flights on November 2000 and February 2001}

Two Infra-Red Montgolfier (MIR) test flights were performed by CNES from Bauru in November 2000, and another three in February 2001. They were organised to test the technological performance of the balloons in the tropics, and additionally provided an opportunity for piggybacking scientific instruments. The first two, purely technical in November 2000 lasted for 18 and 19 days before falling over deep convective cells in Northern Australia showing that the payloads were slightly too heavy for this latitude. The other three carried respectively an IR global radiometer, a SAOZ spectrometer and a LABS diode laser. The LABS flight lasted 49 days (though unfortunately the instrument did not perform properly), while that of the IR radiometer lasted 71 days providing a series of cirrus altitude and brightness temperature. The SAOZ flight lasted for 39 days providing a unique set of 59 ozone, $\mathrm{NO}_{2}$ and cloud profiles (Pommereau et al., 2003; Garnier et al., 2004; Borchi et al., 2005). In addition, two $10000 \mathrm{~m}^{3}$ Zodiac light (ZL) flights were made in order to test several instruments (Table 1), in the meteorological conditions summarized in Table 2. This exploratory campaign offered a first opportunity for studying the impact of deep convection on the composition of the upper troposphere by 3 -D mesoscale simulations in an extreme storm case on 8 February 2001 (Marécal et al., 2006; Rivière et al., 2006).

\subsection{Pre-HIBISCUS/ENVISAT flights in February 2003}

In total, seven balloons were flown: 3 of short duration: with two $10000 \mathrm{~m}^{3} \mathrm{ZL}$ ascending at $30 \mathrm{~km}$ and one $3000 \mathrm{~m}^{3} \mathrm{SF}$ type ascending to $22 \mathrm{~km}$ in the late afternoon to test the feasibility of the slow night-time descent across the TTL following their radiative cooling, and 4 long duration MIRs. The short-duration balloons carried most of the instruments being prepared for the main HIBISCUS campaign. The payload combinations are given in Table 3 and the meteorological conditions encountered are summarized in Table 4. The MIRs carried an improved version of the Inmarsat transmitter, a SAOZ- $\mathrm{H}_{2} \mathrm{O}$, and a prototype of the RUMBA $\mathrm{H}_{2} \mathrm{O}$ $\mathrm{SAW} / \mathrm{O}_{3} \mathrm{SSS}$ payload in preparation for the future constant level superpressure balloons (Garnier et al., 2005). In addition, a number of radiosondes of different types (PTU RS-80, $\mathrm{H}_{2} \mathrm{O}$ SAW/O 3 SSS of UCAM) were flown for test purposes. 
Table 2. Meteorology of the 2001 flights.

\begin{tabular}{llrrrrrrl}
\hline Flight & Date & Min $T^{\circ} \mathrm{C}$ & Alt km & LRT km & PV 380K & PV 475 K & PV 550 K & Comments \\
\hline ZL1 & 15 Feb & -78.6 & 16.9 & 15.4 & -4.9 & -16.7 & -25.1 & SACZ MCS 150 km SW \\
ZL2 & 21 Feb & -78.3 & 17.6 & 15.2 & -4.5 & -16.4 & -25.3 & SACZ MCS 200 S-SW \\
\hline
\end{tabular}

Table 3. List of ENVISAT Pre-HIBISCUS flights in 2003.

\begin{tabular}{lllll}
\hline Instrument (Institute) & Parameter & ZL1 & SF & ZL2 \\
\hline SAOZ Vis, SA & $\mathrm{O}_{3}, \mathrm{NO}_{2}$ profiles & $\mathrm{X}$ & $\mathrm{X}$ & $\mathrm{X}$ \\
SAOZ UV, SA & $\mathrm{BrO}$ profile & $\mathrm{X}$ & $\mathrm{X}$ & $\mathrm{X}$ \\
SAOZ $\mathrm{H}_{2} \mathrm{O}, \mathrm{SA}$ & $\mathrm{H}_{2} \mathrm{O}$ profile & $\mathrm{X}$ & $\mathrm{X}$ & $\mathrm{X}$ \\
DESCARTES, UCAM & $\mathrm{H}_{\text {alogen compounds }}$ & $\mathrm{X}$ & $\mathrm{X}$ & $\mathrm{X}$ \\
DIRAC GC, UCAM & $\mathrm{N}_{2} \mathrm{O}$ & $\mathrm{X}$ & $\mathrm{X}$ & $\mathrm{X}$ \\
DIRAC, GC UCAM & $\mathrm{H}^{2}$ alogen compounds & & & $\mathrm{X}$ \\
SAW Hygrometer, UCAM & $\mathrm{H}_{2} \mathrm{O}$ & & & \\
SSS Ozone sensor, UCAM & $\mathrm{O}_{3}$ & & & \\
Micro-lidar, ENEA/ISAC & $\mathrm{Backscatter} \mathrm{ratio/}$ & & & \\
& polarization & & & \\
\hline
\end{tabular}

Overall, the short-duration flights and the sondes provided a large amount of scientific data, as well as technical information for improving the instruments. Two of the 4 MIR flights were successful, even though of only 9 and 10 days duration as the balloons fell above hurricanes over the Coral Sea and NW Australia.

\subsection{Main HIBISCUS campaign in January-March 2004}

The campaign started on 20 January and ended on 6 March 2004. In total, 18 balloons (6 short- and 12 long-duration) were flown along with 15 small plastic balloon sondes (10 $\mathrm{BKS} / \mathrm{O}_{3}, 3$ ozonesondes and 2 NILUCUBE). The balloon payloads and their performances are summarized in Tables 5 to 9 .

\subsubsection{Short-duration balloons and sondes for mesoscale studies}

The objective was the study of vertical transport, water vapour, chemistry, cirrus clouds and electric field associated with convective cells by dedicated balloon flights in coordination with Falcon aircraft flights and the ground-based measurements of the TROCCIBRAS project. Figure 6 shows the evolution of the meteorology during the campaign and the dates of the balloon and sonde ascents, whose payloads and meteorological conditions encountered are displayed in Tables 5, 6 and 7. On top of the figure is the potential vorticity calculated by the MIMOSA contour advection model. The middle plot shows the 6-hourly ECMWF temperature profile anomaly with respect to the campaign mean. Even though the summer season is on average very convective in South-

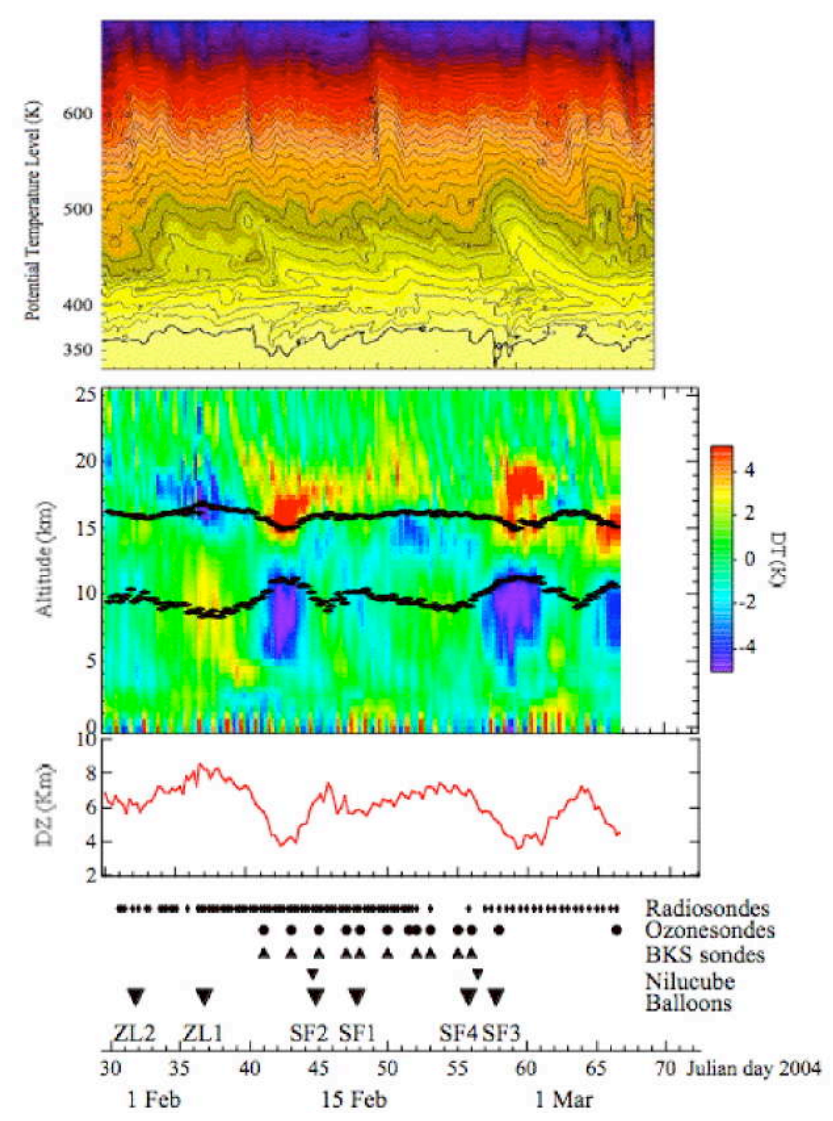

Fig. 6. HIBISCUS balloon and sonde flights in 2004. Top: potential vorticity as a function of potential temperature calculated by the MIMOSA contour advection model (the tropopause at 2 pvu is indicated by a bold line); middle: 6-hourly ECMWF temperature deviation compared to campaign average profile. Black markers show the altitude of the $340 \mathrm{~K}$ and $370 \mathrm{~K}$ potential temperature levels, whose difference used as a convection index, is shown in the bottom panel (red curve). Bottom markers: dates of radiosondes, ozonesondes, backscattersondes, Nilucube and large balloon flights. The intensity of convection above Bauru varies with the slow back and forth displacement of the South Atlantic Convergence Zone (SACZ) and the advection of cold front systems from the SW. Convection was the strongest between 4-8 February (day 35-39) when the troposphere is warmer by $2-4{ }^{\circ} \mathrm{C}$ compared to the average and the region of the tropopause cooler by $2-5^{\circ} \mathrm{C}$, and was of medium intensity during days $45-57$ and $62-65$. Two periods of low convection were experienced from days $41-44$ and 53-56 corresponding to the maximum displacement of the SACZ towards the NE. 
Table 4. Meteorology of ENVISAT-Pre-HIBISCUS flights in 2003.

\begin{tabular}{llrrrrrrl}
\hline Flight & Date & Min $T{ }^{\circ} \mathrm{C}$ & Alt km & LRT km & PV 380K & PV 475K & PV 550K & Comments \\
\hline ZL1 & $18 \mathrm{Feb}$ & -80.1 & 17.9 & 15.4 & -1.34 & -20.6 & -27.7 & MCS below \\
SF & 19 Feb & -79.3 & 17 & 15.6 & -1.05 & -18.3 & -28.2 & Large MCS 300-450 km SW \\
ZL2 & $23 \mathrm{Feb}$ & -82.0 & 18.1 & 1.2 & -3.38 & -18.2 & -28.6 & Large MCS below \\
\hline
\end{tabular}

Table 5. HIBISCUS short duration balloon and sondes (Son) flights in 2004.

\begin{tabular}{|c|c|c|c|c|c|c|c|c|}
\hline Instrument, Institute & Parameter & ZL1 & ZL2 & SF1 & $\mathrm{SF} 2$ & SF3 & SF4 & Son \\
\hline SAOZ Vis, SA & $\mathrm{O}_{3}, \mathrm{NO}_{2}$ profiles & $\mathrm{X}$ & $\mathrm{X}$ & $\mathrm{X}$ & $\mathrm{X}$ & $\mathrm{X}$ & $\mathrm{X}$ & 10 \\
\hline SAOZ UV, SA & $\mathrm{BrO}$ profile & $\mathrm{X}$ & $\mathrm{X}$ & $\mathrm{X}$ & $\mathrm{X}$ & $\mathrm{X}$ & $\mathrm{X}$ & 13 \\
\hline DESCARTES, UCAM & Halogen compounds & $\mathrm{X}$ & $\mathrm{X}$ & $\mathrm{X}$ & $X$ & $\mathrm{X}$ & $\mathrm{X}$ & 2 \\
\hline DIRAC GC, UCAM & Halogen compounds & & & $\mathrm{X}$ & $\mathrm{X}$ & $\mathrm{X}$ & $\mathrm{X}$ & \\
\hline Micro DIRAC, UCAM & Test instrument, CFC11 & & & $\mathrm{X}$ & $\mathrm{X}$ & $\mathrm{X}$ & $\mathrm{X}$ & \\
\hline Micro-SDLA, CNRS & $\mathrm{H}_{2} \mathrm{O}, \mathrm{CH}_{4}, \mathrm{CO}_{2}$ & & & $\mathrm{X}$ & $\mathrm{X}$ & $\mathrm{X}$ & $\mathrm{X}$ & \\
\hline TDLAS, NPL & $\mathrm{H}_{2} \mathrm{O}$ & & & $\mathrm{X}$ & & & & \\
\hline SAW Hygrometer, UCAM & $\mathrm{H}_{2} \mathrm{O}$ & & & $\mathrm{X}$ & & & & \\
\hline SSS Ozone sensor, UCAM & $\mathrm{O}_{3}$ & & & & & & & \\
\hline Micro-lidar, ENEA/ISAC & Backscatter ratio/polariz. & & & & & & & \\
\hline LABS, ISAC & Backscatter ratio/polariz. & & & & & & & \\
\hline BKS sonde DMI, U. Wyo & Backscatter ratio in situ & & & & & & & \\
\hline Optical Counter, UMIST & Aerosol size distribution & & & & & & & \\
\hline ECC Ozone, DMI SA & $\mathrm{O}_{3}$ & & & & & & & \\
\hline NILUCUBE, NILU & $\mathrm{UV}-\mathrm{V}$ is radiation & & & & & & & \\
\hline AIRS, CNRS CETP & Electric field, conductivity & & & & & & & \\
\hline
\end{tabular}

east Brazil, large modulations of intensity are observed associated with the motion of the South Atlantic Convective Zone (SACZ) and large scale Kelvin or Rossby waves (Pommereau and Held, 2007). Black markers indicate the altitude of the $340 \mathrm{~K}$ and $370 \mathrm{~K}$ potential temperature levels whose difference, shown in the bottom panel, is an indicator of convective intensity. Convective periods exhibit a warmer troposphere and a cooler TTL, while low or non-convective periods are marked by a cooler troposphere and a warmer TTL. As seen in the PV cross-section, whose values for each flight at 380, 475 and $550 \mathrm{~K}$ are summarized in Table 6 , most of the flights were performed within tropical air pulses (low PV), with the exception of the first on 31 January, which was the closest to the sub-tropical jet stream, but still in the TTL. A summary of convective activity encountered during each flight, provided by the radar and GOES-E images, is given in Table 6. More details can be found in Appendix B. Meteorological radiosondes were launched four times per day between 5-21 February, as indicated by markers at the bottom of the figure.

\subsubsection{Long-duration balloon flights}

The flight programme included 8 constant-level superpressure balloons (SBP), and 3 MIRs. The SBP were of two types: $10 \mathrm{~m}$ diameter floating at $55 \mathrm{hPa}(\sim 19 \mathrm{~km})$ and $8.50 \mathrm{~m}$ diameter at $75 \mathrm{hPa}(\sim 18 \mathrm{~km})$ i.e. above and at about the cold point tropopause level. The list of flights, their instrumentation, the dates of launch and their duration are given in Table 8, and the trajectories of the balloons displayed in Fig. 7. Apart from a transmitter failure on BP2 and a small leak on BP1, which depressurised and fell after 13 days, all others remained at float for 1-2 months. All GPS and meteorological sensors performed well, providing useful scientific products (3-D trajectories, temperature and pressure fluctuations) for studying gravity and Rossby waves. However, the water vapour instrument did not work properly, likely because of limited $\mathrm{H}_{2} \mathrm{O}$ deposition due to inadequate ventilation, and the ozone sensors stopped transmitting their information to the main gondola after 14 and 3 days, respectively.

The instrumentation carried by the MIRs, the dates of their launch and their duration in flight are given in Table 9 and their trajectories shown in Fig. 8. Of the four attempts, one failed at launch and was replaced by a spare balloon. The 3 MIRs remained in flight for respectively 7, 39 and 9 days. The relatively short flight of two of them was due to fast descent over high-level clouds in the evening. These anomalous events have since been identified by CNES as due to the small size of the aperture at the bottom of the MIRs which 
Table 6. Meteorology of HIBISCUS balloon flights in 2004.

\begin{tabular}{crrrrrrrl}
\hline Flight & Date & Min $T^{\circ} \mathrm{C}$ & Alt km & LRT km & PV 380K & PV 475K & PV 550K & Comments \\
\hline ZL2 & 31 Jan & -77.1 & 17.4 & 15.2 & -4.56 & -21.3 & -29.8 & $\begin{array}{l}\text { SACZ, Convective cells 10- } \\
11 \mathrm{~km} \text { high at 60-100 km SE. }\end{array}$ \\
ZL1 & 5 Feb & -81.1 & 16.9 & 16.2 & -2.54 & -14.6 & -26.6 & $\begin{array}{l}\text { SACZ, intense MCS 150 km } \\
\text { S-SW, }\end{array}$ \\
SF2 & 13 Feb & -78 & 18 & 15.2 & -4.33 & -16.5 & -24.2 & $\begin{array}{l}\text { Intense 300 km large MCS } \\
150 \mathrm{~km} \mathrm{W-NW}\end{array}$ \\
SF2 & 16 Feb & -78 & 15.5 & 15.7 & -5.05 & -14.3 & -25.2 & $\begin{array}{l}\text { South of SACZ, convection } \\
\text { free, }\end{array}$ \\
SF4 & 24 Feb & -78.7 & 18.0 & 14.8 & -3.14 & -17.8 & -24.2 & $\begin{array}{l}\text { SACZ intense afternoon } \\
\text { convection }\end{array}$ \\
SF3 & 26 Feb & -79 & 17.8 & 15.2 & -4.00 & -18.6 & -23.8 & $\begin{array}{l}\text { Active thunderstorms } 150 \mathrm{~km} \\
\text { South }\end{array}$ \\
\hline
\end{tabular}

Table 7. Dates and type of HIBISCUS sondes (BKS: backscatter; $\mathrm{O}_{3}$ : ECC ozonesonde, and NILUCUBE).

\begin{tabular}{|c|c|c|}
\hline Date UT time & Instruments & Max altitude and Comments \\
\hline 10 Feb 00:59 & $\mathrm{BKS}, \mathrm{O}_{3}$ & $28.5 \mathrm{~km}$ No cirrus \\
\hline 11 Feb 23:57 & $\mathrm{BKS}, \mathrm{O}_{3}$ & $28.0 \mathrm{~km}$ Thin cloud layer at $9-10 \mathrm{~km}$ \\
\hline 13 Feb 13:00 & NILUCUBE & $20 \mathrm{~km}$. Clear sky. Bright low alt cumulus \\
\hline 13 Feb 22:35 & $\mathrm{BKS}, \mathrm{O}_{3}$ & $\begin{array}{l}\text { SF2, } 26.9 \mathrm{~km} \text {, Thin cirrus up to } 13 \mathrm{~km} \approx \text { app. } 2 \mathrm{~km} \text { below bottom of } \\
\text { TTL }\end{array}$ \\
\hline 16 Feb 00:07 & $\mathrm{BKS}, \mathrm{O}_{3}$ & $28.4 \mathrm{~km}$. No cirrus \\
\hline 17 Feb $00: 05$ & $\mathrm{BKS}, \mathrm{O}_{3}$ & SF1. $26.9 \mathrm{~km}$. No cirrus \\
\hline 19 Feb 00:07 & $\mathrm{BKS}, \mathrm{O}_{3}$ & $27.7 \mathrm{~km}$. Very thin cirrus up to $14 \mathrm{~km}$ \\
\hline 20 Feb 15:35 & $\mathrm{O}_{3}$ & $33 \mathrm{~km}$ \\
\hline $20 \mathrm{Feb} 23: 58$ & $\mathrm{BKS}, \mathrm{O}_{3}$ & $\begin{array}{l}25.4 \mathrm{~km} \text {. Thick }(2-3 \mathrm{~km}) \text { cirrus up to bottom of TTL at } 14.4 \mathrm{~km} \text {. Un- } \\
\text { usual aerosol layer at } 16.5-18 \mathrm{~km} \text { only seen on descent. Close to local } \\
\text { thunderstorms. }\end{array}$ \\
\hline 21 Feb 22:24 & $\mathrm{BKS}, \mathrm{O}_{3}$ & $\begin{array}{l}33.2 \mathrm{~km} \text {. Very thin cirrus layer at the bottom of the TTL at } 15 \mathrm{~km} \text {, only } \\
\text { seen on descent. Launched close to local thunderstorms. }\end{array}$ \\
\hline 23 Feb 22:41 & $\mathrm{BKS}, \mathrm{O}_{3}$ & $\begin{array}{l}26.1 \mathrm{~km}\left(\mathrm{O}_{3} \text { unreliable above } 22.6 \mathrm{~km}\right) \text {. Thick cloud layer up to } 13 \mathrm{~km} \text {. } \\
\text { Launched downwind of convective systems. }\end{array}$ \\
\hline $24 \mathrm{Feb} 22: 30$ & $\mathrm{BKS}, \mathrm{O}_{3}$ & $\begin{array}{l}\text { SF4. } 28.7 \mathrm{~km} \text {. Very thin cirrus layers up to } 15 \mathrm{~km} \text {. Thick cloud layer up } \\
\text { to } 14 \mathrm{~km} \text {. Launched downwind of convective systems. Depolarisation } \\
\text { data. }\end{array}$ \\
\hline 25 Feb 15:00 & NILUCUBE & $20 \mathrm{~km}$. Overcast conditions by high altitude cirrus \\
\hline 26 Feb 23:35 & $\mathrm{O}_{3}$ & SF3. $30.1 \mathrm{~km}$. \\
\hline 6 Mar 23:00 & $\mathrm{O}_{3}$ & $31.7 \mathrm{~km}$ \\
\hline
\end{tabular}

caused a reduction of volume when the balloon is cooling and descending after sunset. MIR-1 provided limited data after the partial failure of the SAOZ detector at low temperature. The other two were successful. The micro-lidar flown on MIR-2 measured a number of cloud profiles, although some of the measurements were noisy as a result of electrical interference in the Inmarsat transmitter. The SAOZ on board MIR-3 provided the longest ever series of profiles (78) of $\mathrm{O}_{3}, \mathrm{NO}_{2}$ and cloud extinction in the tropical UTLS, as well as for the first time $\mathrm{H}_{2} \mathrm{O}$. For comparison purpose, dedicated ozonesondes ascents were performed during the overpass of the balloon over the SHADOZ stations of Samoa, Fiji and Reunion Island, and from Bauru at launch. Unfortunately, high-altitude clouds, associated with the Gafilo hurricane in the Indian Ocean, prevented co-located ozone lidar observations at Reunion Island, as carried out in 2001 for checking the altitude registration of the retrievals. All meteorological sensors, as well as the global IR radiometer and the lightning optical detectors performed well on all flights. 
Table 8. HIBISCUS Super pressure balloon (SPB) flights in 2004: balloon diameter, instrumentation, date of launch and duration.

\begin{tabular}{lllll}
\hline Balloon & Instrument & Start & Dur. & Comments \\
\hline BP1 $10 \mathrm{~m}$ & Met, turbulence LMD & $6 \mathrm{Feb}$ & $13 \mathrm{~d}$ & Telemetry failed after few hours \\
BP2 $8.5 \mathrm{~m}$ & Met, $\mathrm{O}_{3} / \mathrm{H}_{2} \mathrm{O}$ UCAM & $12 \mathrm{Feb}$ & $1 \mathrm{~d}$ & No SSS/SAW data after $14 \mathrm{~d}$ \\
BP3 $10 \mathrm{~m}$ & Met, turbulence LMD & $12 \mathrm{Feb}$ & $53 \mathrm{~d}$ & No SSS/SAW data after $3 \mathrm{~d}$ \\
BP4 $8.5 \mathrm{~m}$ & Met sensors & $29 \mathrm{Feb}$ & $80 \mathrm{~d}$ & No turbulence data after $7 \mathrm{~d}$ \\
BP5 $10 \mathrm{~m}$ & Met, $\mathrm{O}_{3} / \mathrm{H}_{2} \mathrm{O}$ UCAM & $6 \mathrm{Mar}$ & $39 \mathrm{~d}$ & \\
BP6 $8.5 \mathrm{~m}$ & Met, turbulence LMD & $7 \mathrm{Mar}$ & $56 \mathrm{~d}$ & \\
BP7 $10 \mathrm{~m}$ & Met, $\mathrm{O}_{3} / \mathrm{H}_{2} \mathrm{O}$ UCAM & $9 \mathrm{Mar}$ & $27 \mathrm{~d}$ & \\
BP8 $10 \mathrm{~m}$ & Met sensors & $11 \mathrm{Mar}$ & $37 \mathrm{~d}$ & \\
\hline
\end{tabular}

Table 9. IR Montgolfier flights instrumentation, date of launch, duration, cause of termination.

\begin{tabular}{|c|c|c|c|c|c|}
\hline Year & Flight & Instrument & LaunchDate & Flight days & Comments \\
\hline 2001 & MIR1 & $\mathrm{SAOZ} \mathrm{O}_{3}, \mathrm{NO}_{2}$ & $13 \mathrm{Feb}$ & 39 & $\begin{array}{l}\text { Cut above thunderstorm in } \\
\text { Argentina }\end{array}$ \\
\hline 2001 & MIR2 & & $15 \mathrm{Feb}$ & 71 & $\begin{array}{l}\text { Inmarsat test flight, terminated } \\
\text { by end of power }\end{array}$ \\
\hline 2001 & MIR3 & O3SS, LABS, Rumba & $21 \mathrm{Feb}$ & 49 & Terminated by end of power \\
\hline 2003 & MIR1 & $\begin{array}{l}\mathrm{SAOZ} \mathrm{O}_{3}, \mathrm{NO}_{2} \text {, Lightning det., } \\
\text { IR Radiometer }\end{array}$ & $20 \mathrm{Feb}$ & 9 & $\begin{array}{l}\text { Cut above tropical storm in NE } \\
\text { Australia }\end{array}$ \\
\hline 2003 & MIR2 & $\mathrm{SAOZ} \mathrm{O}_{3}, \mathrm{NO}_{2}$ & $23 \mathrm{Feb}$ & 10 & $\begin{array}{l}\text { New Lightweight MIR, Cut } \\
\text { above hurricane in Coral sea }\end{array}$ \\
\hline 2004 & MIR1 & $\begin{array}{l}\mathrm{SAOZ} \mathrm{O}_{3}, \mathrm{NO}_{2}, \mathrm{H}_{2} \mathrm{O}, \mathrm{IR} \\
\text { radiometer, met sensors }\end{array}$ & $4 \mathrm{Feb}$ & 9 & $\begin{array}{l}\text { SAOZ detector malfunction Cut } \\
\text { above tropical storm in NW } \\
\text { Australia }\end{array}$ \\
\hline 2004 & MIR2 & $\begin{array}{l}\mathrm{SAOZ} \mathrm{O}_{3}, \mathrm{NO}_{2}, \mathrm{H}_{2} \mathrm{O} \text {, IR ra- } \\
\text { diometer, met sensors Light- } \\
\text { ning detector }\end{array}$ & $26 \mathrm{Feb}$ & 39 & $\begin{array}{l}\text { Cut above thunderstorm in the } \\
\text { Southwest Pacific }\end{array}$ \\
\hline 2004 & MIR3 & $\begin{array}{l}\text { Micro-lidar IR radiometer, met } \\
\text { sensors }\end{array}$ & $10 \mathrm{Mar}$ & 7 & $\begin{array}{l}\text { Noise in micro-lidar, Cut above } \\
\text { thunderstorm in the Southwest } \\
\text { Pacific }\end{array}$ \\
\hline
\end{tabular}

\section{Results highlights}

The rich observational data set collected during the HIBISCUS campaigns has been used for a variety of investigations: (i) the impact of convection on the thermal structure, the composition and the water vapour concentration in the TTL and the lower stratosphere; (ii) the identification of possible biases in NWP model temperatures in the lower stratosphere and trends in their re-analyses, by comparison with measurements of French long duration balloons flights performed in the tropics since 1988; and (iii) the evaluation of ozone, water vapour, and chemical species satellite retrievals in the tropics. The most important findings are highlighted below.

\subsection{Local impact of convection on the thermal structure and the composition of the TTL}

The impact of convection on the thermal structure of the TTL was explored from the diurnal variation of temperature derived from the series of four daily radiosondes performed in Bauru (Pommereau and Held, 2007). During the most intense convective period, between 3-9 February, a systematic cooling was observed in the afternoon at the altitude of CPT around $17-18 \mathrm{~km}(380-400 \mathrm{~K})$ in coincidence with the maximum development of convective systems seen by the S-band Doppler radar reporting echo-tops reaching 18$19 \mathrm{~km}$ (Fig. 9). The diurnal cycle in temperature and echotop in the TTL, similar to that reported at $80 \mathrm{hPa}$ during the monsoon season in Western Africa (Cairo et al., 2010) and to that of the overshooting precipitation features (OPF) of the TRMM Precipitation Radar by Liu and Zipser (2005), 


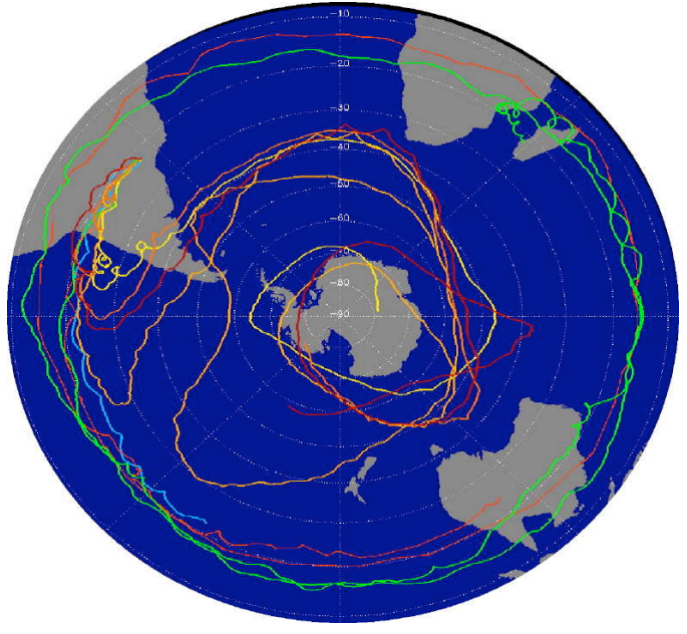

Fig. 7. Trajectories of the 8 super pressure balloons. Those launched before 12 February remained at tropical latitudes, while those flown later after a break of 17 days, were rapidly captured by the mid-latitude westerly flow after crossing the tropical barrier. The loops in the trajectories, particularly in the tropics, are due to inertia gravity waves not adequately captured in the ECMWF model.

provides evidence of strong impact of land convective systems on the thermal structure of the lower stratosphere, as suggested by Danielsen (1982). Although gravity waves and vertical diffusivity might also partly contribute, the suggestion is that uplifting in the lower stratosphere associated with fast developing land convection in the afternoon, is a significant contributor to troposphere-stratosphere exchange (Pommereau and Held, 2007). The suggestion is supported by non-hydrostatic regional model simulations displaying a cooling of up to $15 \mathrm{~K}$ at the altitude of the cold point above convective towers (Chaboureau et al., 2007; Grosvenor et al., 2007; Jensen et al., 2007), although the diurnal cycle of convection is still poorly simulated. This contrasts with oceanic areas, where less intense cooling is observed, which is limited to the altitude of the lapse rate tropopause at around $16 \mathrm{~km}$ (Sherwood et al., 2003).

The local vertical transport has also been explored by calculating the equivalent diffusivity, required for explaining the high-resolution ozone, water vapour and methane profiles recorded by the balloons (Pisso and Legras, 2008). It was shown that the vertical transport in those case studies would require a vertical diffusivity of $0.5 \mathrm{~m}^{2} \mathrm{~s}^{-1}$, significantly larger than the $0.1 \mathrm{~m}^{2} \mathrm{~s}^{-1}$ value estimated by the authors using the same technique at mid-latitude (Legras et al., 2005) or the average $0.02 \mathrm{~m}^{2} \mathrm{~s}^{-1}$ derived by Mote et al. (1998) from $5 \mathrm{yr}$ methane profiles measurements by the Halogen Occultation Experiment (HALOE). However, the respective contribution of small-scale turbulence, gravity waves or convective overshooting to this extreme equivalent diffusivity, is still an open question.

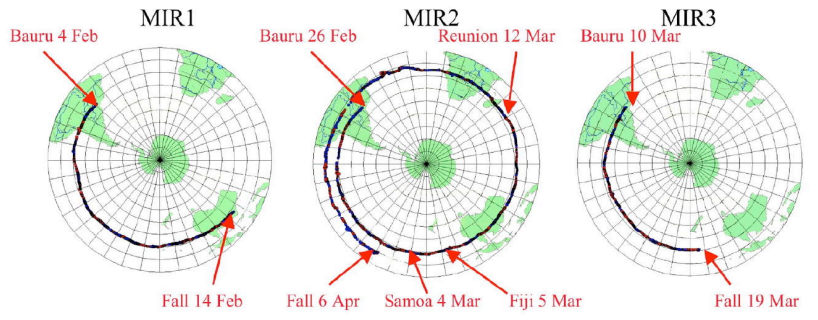

Fig. 8. MIR trajectories in 2004. MIR1 carrying a SAOZ lasted in flight for 9 days before falling in the evening above a tropical storm in NW Australia where it was recovered. MIR2 remained in flight for 39 days between $20^{\circ}$ and $10^{\circ} \mathrm{S}$, providing 78 profiles of $\mathrm{O}_{3}, \mathrm{NO}_{2}, \mathrm{H}_{2} \mathrm{O}$ and cloud extinction between $6 \mathrm{~km}$ or cloud top and $25 \mathrm{~km}$. Co-located ozonesonde ascents were made at the SHADOZ stations of Samoa, Fiji and Reunion Island. The flight ended over a thunderstorm in the South Pacific Convergence Zone. Although only of 8-day duration, MIR3 enabled cloud measurements by a micro-lidar, flown for the first time on a long-duration balloon, together with the IR global radiometer.

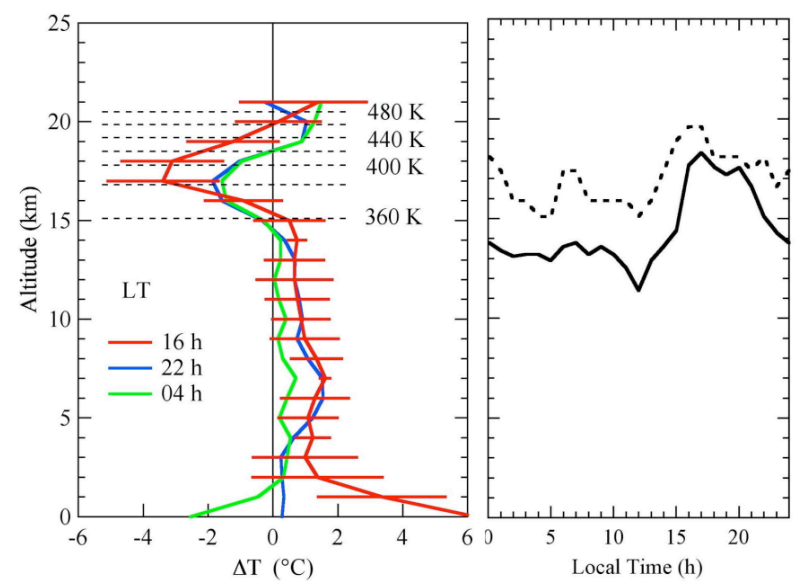

Fig. 9. Impact of convection on the thermal structure of the UTLS. Left: change of temperature between 16:00, 22:00 and 04:00 h local time and $10 \mathrm{~h}$ during the most intense convective period (error bars are showing the standard deviation). Right: diurnal variation of mean (solid) and maximum (dotted) echo-top height seen during the same period by the S-band Doppler radar within its $240 \mathrm{~km}$ range (Pommereau and Held, 2007).

A wide range of tracers was measured in both the 2003 and 2004 campaigns on board ZL and SF balloons. Halocarbons, of lifetime ranging from $85 \mathrm{yr}$ (CFC-113) to 36 months (chloroform), and $\mathrm{N}_{2} \mathrm{O}$ measurements were made by the DIRAC in situ gas chromatograph (GC) and the DESCARTES grab samplers. The picture painted from the data is of a TTL rich in spatial structure. The long-lived halocarbons measured in the troposphere were generally well mixed (showing little vertical gradient). There was some suggestion of boundary layer enhancement. On some flights 
mixing ratios above-background levels could be observed in long-lived tracers just below the TTL layer, which could indicate uplift of boundary layer air (e.g., CFC-113 on SF1 and SF3). The long-lived tracers again showed no vertical gradient across the TTL between 350 and $400 \mathrm{~K}$. Only above $400 \mathrm{~K}$ was there a noticeable drop-off in the long-lived tracer-mixing ratio, indicating stratospheric aged air. The long-lived tracers are also anti-correlated with the co-located ozone measurements in this region

In the case of the shorter-lived halocarbon tracers below and inside the TTL region, much more variability was found in the vertical profiles. While the long-lived tracers show little gradient or variability in the 350 to $400 \mathrm{~K}$ region, the shorter-lived tracers show considerable variation. In the case of chloroform ( $\sim 6$ months lifetime), there is a decrease in mixing ratio of around 3 ppt between 350 and $400 \mathrm{~K}$ (amounting to some $50 \%$ of the tropospheric value). In the case of dibromomethane ( 3 to 4 month lifetime), the tracer distribution is more difficult to describe, since there is a slight drop-off between 350 and $400 \mathrm{~K}$, but there is evidence of a maximum in the 360 to $380 \mathrm{~K}$ region, consistent with reasonably recent uplift from the boundary layer. Unfortunately, dibromomethane was only measured by the DESCARTES grab samplers and so the vertical resolution is low. A first attempt to explain the tracer vertical structure using the simple 1-D model introduced by Folkins et al. (1999) was unsuccessful. It was not possible to reproduce all the profiles with a single vertical velocity. It is clear that this model (while having been extremely influential) must now be considered too simple. The overall structure of the TTL is complex and three-dimensional.

In another modelling study, the impact on the composition of UTLS of a strong convective storm that occurred during the first HIBISCUS campaign on 8 February 2001 was simulated with the 3-D mesoscale RAMS model coupled on-line with a chemistry model. Analysed were the impact on $\mathrm{CO}$, $\mathrm{NO}_{\mathrm{x}}$, non-methane volatile organic and $\mathrm{HO}_{\mathrm{x}}$ (Marécal et al., 2006) and ozone (Rivière et al., 2006) were analysed, and it was been shown that the distribution of $\mathrm{CO}$ with altitude is closely related to the upward convective motions and consecutive outflow at the top of the convective cells leading to a bulge of $\mathrm{CO}$ between $7 \mathrm{~km}$ altitude and the tropopause, consistent with satellite-borne measurements at $700 \mathrm{hPa}$. The simulation also indicates enhanced amounts of $\mathrm{NO}_{\mathrm{x}}$ up to $2 \mathrm{ppbv}$ in the $7-17 \mathrm{~km}$ altitude layer mainly produced by the lightning associated with the intense convective activity. For insoluble non-methane volatile organic compounds, the convective activity tends to significantly increase their amount in the $7-17 \mathrm{~km}$ layer by dynamical effects. During daytime in the presence of lightning $\mathrm{NO}_{\mathrm{x}}$, this bulge is largely reduced in the upper part of the layer for reactive species (e.g. isoprene, ethene) because of their reactions with $\mathrm{OH}$ that is increased on average during daytime. Lightning $\mathrm{NO}_{\mathrm{x}}$ also impacts on the oxidizing capacity of the upper troposphere by reducing on average $\mathrm{HO}_{\mathrm{x}}, \mathrm{HO}_{2}, \mathrm{H}_{2} \mathrm{O}_{2}$ and organic hy- droperoxides. However, the impact of convection on the air composition of the lower stratosphere was found to be negligible in the BRAMS simulations in the absence of fast transport process across the tropopause like in the previous 1-D model.

In this model, the ozone concentration in the TTL during this event was found compatible with ozonesonde observations, showing that fast ozone variations over the convective system are mainly driven by horizontal transport (Rivière et al., 2006). When averaged over the $24 \mathrm{~h}$ period, the simulations suggest that convective activity is the main driver explaining $70 \%$ of the total ozone increase in the TTL, while chemical production contributes to $29 \%$ of the ozone increase when the $\mathrm{NO}_{\mathrm{x}}$ production by lightning is taken into account. Also shown is that downward motion at the tropopause induced by gravity waves associated to deep convection, contributes for $24 \%$ to the ozone increase.

In summary, temperature, tracers and ozone observed profiles next to convectively active systems are all showing large changes in the TTL and the lower stratosphere. Consistent with fast transport of tropospheric air across the tropopause by convective overshooting towers suggested by Danielsen (1982), those variations are well captured by a 3-D meso-scale model in the upper troposphere but not above in the lower stratosphere in the absence of fast vertical transport process in the model.

\subsection{Hydration of the lower stratosphere over land convective systems}

Several water vapour measurements in the TTL and the lower stratosphere are available, from the balloons with in situ $\mu$ SDLA and SAW and remote SAOZ sensors, and from satellite instruments, the Halogen Occultation Experiment (HALOE), the Stratospheric Aerosol and Gas Experiment (SAGE II), the Global Ozone Monitoring by Occultation of Stars (GOMOS), the Michelson Interferometer for Passive Atmospheric Sounding (MIPAS) and the Atmospheric Infrared Sounder (AIRS). As an example, Fig. 10 shows the in situ measurements performed during a balloon slow descent between 20 and $12 \mathrm{~km}$ on 13 February together with the closest available satellite observations (Montoux et al., 2009). The $\mu$ SDLA and SAW measurements in the upper troposphere show super-saturated mixing ratios (MR) up to the Lapse Rate Tropopause (LRT) at $15.2 \mathrm{~km}$ above which, the MR ranges between 3.5 and $5 \mathrm{ppm}$. No significant dehydration was observed at the relatively warm sub-saturated cold point of $-78^{\circ} \mathrm{C}$ around $18 \mathrm{~km}$, though there were interleaved but drier ( $3.5 \mathrm{ppm})$ and moister (5 ppm) layers, highly correlated with $\mathrm{CH}_{4}$ and $\mathrm{PV}$, and anticorrelated with ozone and temperature (Durry et al., 2006). These measurements reveal a complex structure with signs of convective uplift of moist air from the upper troposphere to the TTL ( $5 \mathrm{ppm}$ up to $18 \mathrm{~km}, 400 \mathrm{~K})$ and of dry layers linked to stratospheric intrusions. The possible location and time of the convective event, 


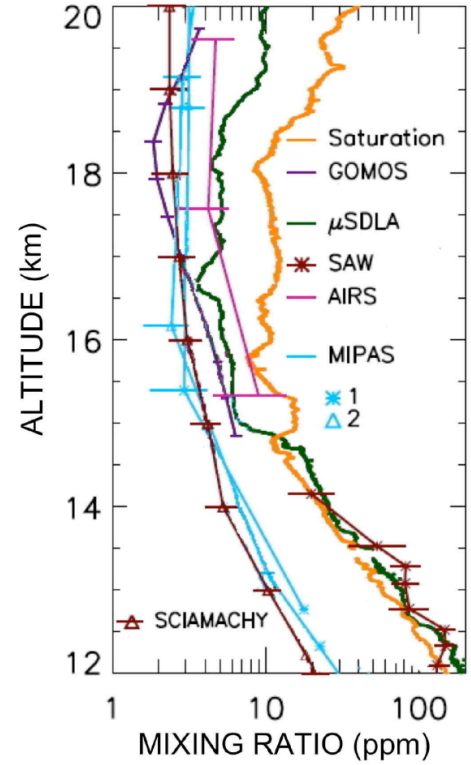

Fig. 10. Water vapour mixing ratio measurements around Bauru on 13 February 2004: in situ $\mu$ SDLA (green) and SAW (purple) during the balloon slow descent, GOMOS (black), MIPAS (blue, 2 profiles) and AIRS (pink) closest measurements and saturation ratio (yellow) (Montoux et al., 2009).

responsible for the supersaturated layers and the cirrus clouds reported on the same flights by the micro-lidar, was explored by Marécal et al. (2007) using backward 3-D trajectories calculated from outputs of the BRAMS. The analysis showed that in sub-saturated layers the water vapour profile depends mainly on the dynamics, while in saturated/supersaturated layers, microphysical processes have also to be taken into account. SCIAMACHY, MIPAS and GOMOS are reporting mixing ratios significantly dryer than those of the in situ sensors. AIRS is the only satellite instrument reporting consistent measurements with of those of the balloons in the upper troposphere.

An extended near IR version of SAOZ was flown for 39 days on a MIR balloon in February-April 2004 during which it completed one and a half circumnavigations of the globe. The water vapour profiles derived from the 78 profiles (Fig. 11) show s a minimum mixing ratio (hygropause) at around $18 \mathrm{~km}, 1.5-2 \mathrm{~km}$ above the cold point tropopause, and a zonal modulation with higher mixing ratio of the order of 5 ppm above continents compared to about $3 \mathrm{ppm}$ over subsident oceanic areas. The zonal contrast suggests either additional moistening over land or further dehydration over oceans, though the temperature is not colder there, or advection of drier air from the mid-latitude stratosphere.

Several cloud-measuring instruments were also flown during HIBISCUS: the micro-lidar (Fig. 12) and the backscatter sondes on short-duration balloons, as well as the SAOZ solar occultation spectrometer and the micro-lidar on the MIR

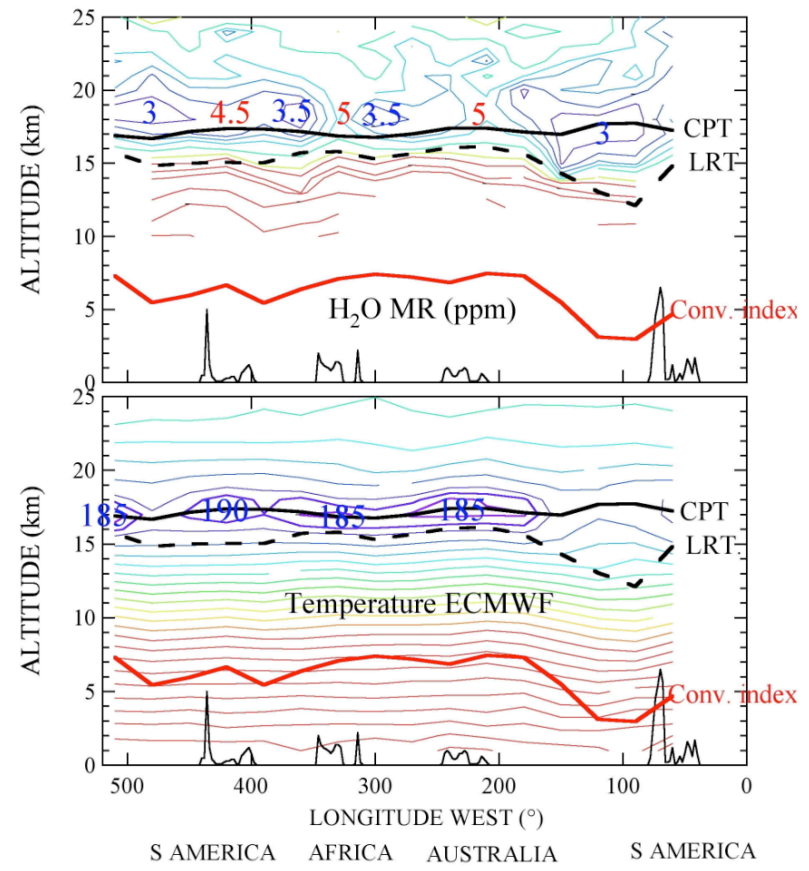

Fig. 11. Water vapour mixing ratio in the UTLS (top) measured by the SAOZ spectrometer and ECMWF temperature (bottom) between $10^{\circ}-20^{\circ} \mathrm{S}$ along the 39 days MIR flight in February-April 2004. A minimum water vapour (hygropause) is observed $3-4 \mathrm{~km}$ above the Lapse Rate Tropopause (LRT, dashed black line), 1.5$2 \mathrm{~km}$ above the cold point (CPT, solid black line), with maxima of $5 \mathrm{ppm}$ over the continents where the temperature is the lowest and minima of 3-3.5 ppm over oceanic subsident areas. The red line shows the difference of altitude between the 370 and $340 \mathrm{~K}$ levels indicative of convection intensity (Pommereau et al., 2006).

for extending the observations to the global scale. Among the results was the frequent detection of anvils up to $14 \mathrm{~km}$ with differences in the particle size distribution depending on the age of production (Fierli et al., 2008), and ultra-thin cirrus at the lapse rate tropopause in the vicinity of convective systems, but never higher. An unexpected new feature observed twice by the backscatter sondes (BKS) above strong convection, was the sporadic presence of small particles up $21 \mathrm{~km}$ in highly sub-saturated levels (Fig. 13) in the vicinity of storm turrets reaching $20( \pm 1) \mathrm{km}$ according to radar images (Nielsen et al., 2007). Though the $0.2-1.5 \mu \mathrm{m}$ radius of those particles is similar to the 1-7-4.7 $\mu \mathrm{m}$ nitric acid containing crystals (NAT) observed at $18 \mathrm{~km}$ by the NASA WB-57F aircraft over the equatorial eastern Pacific Ocean in January 2004 (Popp et al., 2006), their number density of $0.03-1 \mathrm{~cm}^{-3}$, far larger than the $10^{-4} \mathrm{~cm}^{-3}$ of the NAT particles, requiring an additional nucleation process as discussed in Nielsen et al. (2007). The presence of such dense particles was also reported in the same region at $18.2 \mathrm{~km}(410 \mathrm{~K})$ by the Geophysica Aircraft during the TROCCINOX deployment in 2005 (Chaboureau et al., 2007). 


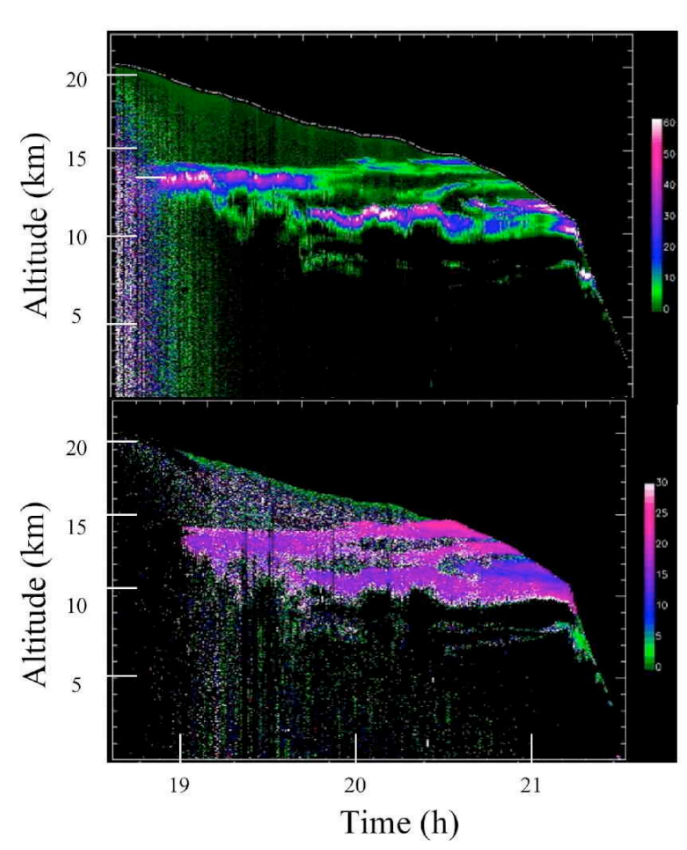

Fig. 12. Micro-lidar cirrus clouds measurements during a nighttime balloon slow descent on 24 February 2004. Top: scattering ratio, bottom: depolarization (Di Donfrancesco et al., 2005).

The HIBISCUS episode has been simulated with the UK Met Office Cloud Resolving Model (Grosvenor et al., 2007). This model has a bulk microphysics scheme (size spectra are assumed to follow gamma distributions), which is double moment for the ice hydrometeors. The model was initialised using a sounding from Bauru and convection started using a warm and moist-bubble of 3 different rates of heating and moistening to produce separate simulations of overshoots of different strengths. It was found that in all cases the clouds mixed some of the ice-laden air carried by them with stratospheric air. The warming experienced as a result caused some of the ice to evaporate leaving moist air plumes in the stratosphere with water vapour exceeding $10 \mathrm{ppm}$ in the most vigorous case (Fig. 14). The mixing and warming also meant that the air attained stratospheric potential temperatures and thus would be likely to remain in the stratosphere. The mass of extra water vapour injected into the stratosphere was calculated for the three different cases and came to 1116, 194 and 86 tonnes in the strong, medium and weak cases respectively. Thus, there was a large difference between the different cases indicating that a small change in overshooting distance can produce a large difference in the amount of water deposited in the stratosphere. These conclusions are consistent with those reached by Chaboureau et al. (2007) from a cloud resolving model simulation of another event during the TROCCINOX campaign, suggesting that the flux of additional water at $410 \mathrm{~K}$ could be of 5 tonnes $\mathrm{s}^{-1}$, that is of the order of 3000 tonness for an event lasting $10 \mathrm{~min}$.

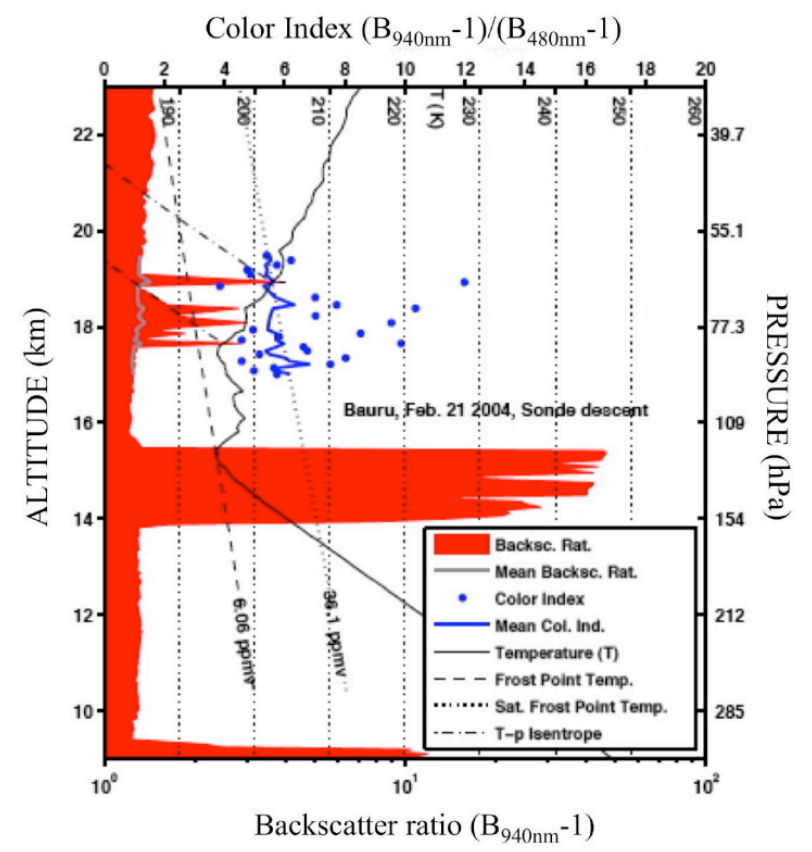

Fig. 13. Backscatter sounding on 21 February. Red filled area: backscatter ratio at $940 \mathrm{~nm}$; blue dots: colour index; thin black line: temperature; dashed line: frost point assuming $6.06 \mathrm{ppm}$ WV mixing ratio; dotted line: same but assuming $36.1 \mathrm{ppm}$. Particles are observed between $17.5-19 \mathrm{~km}$ above a cumulo-nimbus anvil of radii estimated of the order of 0.2-1.5 $\mu \mathrm{m}$. (Nielsen et al., 2007).

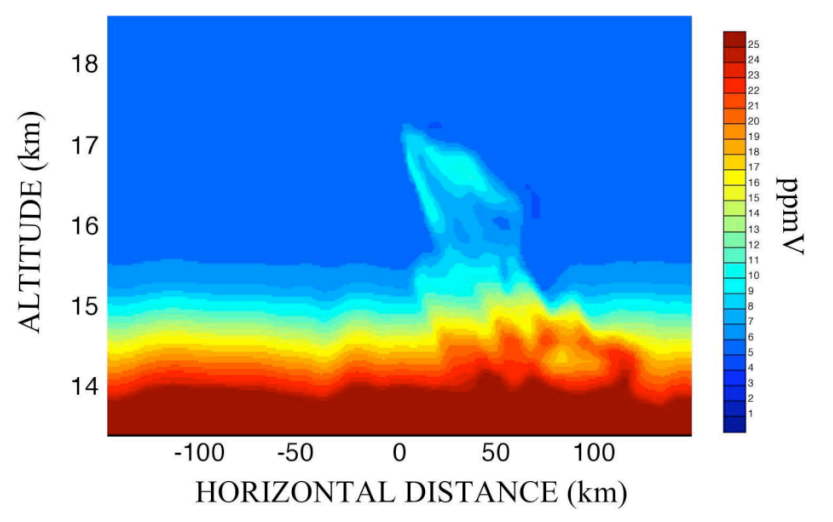

Fig. 14. Vertical cross section of the vapour mixing ratio in the plume produced by the overshoot in the most vigorous of the 3D simulations performed using the UK Met Office Cloud resolving model after $1 \mathrm{~h} 35 \mathrm{~min}$ of simulation time. At this time the plume air was stable in the stratosphere having attained stratospheric potential temperatures through mixing with stratospheric air (Grosvenor et al., 2007).

Grosvenor et al. (2007) also performed microphysical sensitivity tests since the ice size distribution in the overshoot is likely to be important in determining how much of the ice falls from the stratosphere and how much evaporates within 
it. This was based on the strongest case with the number of $\mathrm{CCN}$ at cloud base increased from 240 to $960 \mathrm{~cm}^{-3}$. This had the effect of increasing the number of droplets that survived the riming process within the main updraught to freeze at the $-38^{\circ} \mathrm{C}$ homogeneous freezing level at $\sim 11 \mathrm{~km}$. Smaller ice crystals were therefore present in the overshooting cloud and this resulted in more evaporation of ice, due to their lower fall speeds, producing an extra 118 tonnes of stratospheric vapour increase. In addition, much more of the water transported into the stratosphere remained as ice in this case (505 tonnes compared to 131 tonnes in the normal CCN case) due to the slow ice fall speeds. Hence, if the remaining ice can later evaporate before falling from the stratosphere, a significant increase in the total moistening of $45 \%$ is predicted due to the $\mathrm{CCN}$ increase. This suggests that anthropogenic aerosol emissions may play a role in determining the amount of moistening produced by overshoots and possibly therefore the global water flux into the stratosphere if the overall effect of overshoots is globally important.

In summary, the HIBISCUS and TROCCINOX water vapour and particles measurements were all suggesting moistening of the lower stratosphere by injection of ice crystals by overshooting towers over a convective land region, as observed over Northern Australia (Kelly et al., 1993; Knollenberg et al., 1993; Corti et al., 2008), and Africa (Khaykin et al., 2009), confirmed by the heavier isotopic composition of the water vapour in the stratosphere, characteristic of ice lofted from the troposphere, as observed by Hanisco et al. (2007) in situ on the NASA WB-57 aircraft, or remotely by the MIPAS HDO measurements in the stratosphere (Steinwagner et al., 2010). The process, successfully simulated by Grosvenor et al. (2007) and Chaboureau et al. (2007), is now consistently reproduced by meso-scale non-hydrostatic models (Jensen et al., 2007; Chemel et al., 2009; Hassim et al., 2010).

\subsection{Impact of convective lofting and meridional exchange at the global scale}

There is evidence from the previous sections of deep, local convective overshooting of tropospheric air over Southern Brazil into the lower stratosphere. The open question is how much the mechanism could contribute to troposphere-tostratosphere transport (TST) at the global scale (Flueglistaler et al., 2009). The HIBISCUS long duration balloon and satellites observations provided new unique insights into this subject.

The relative contributions of quasi-horizontal and vertical transport to the variation of ozone concentration in the subtropical UTLS around $10^{\circ}-20^{\circ} \mathrm{S}$ were explored by Borchi et al. $(2005,2007)$ from the variability of ozone profiles provided by the circum-navigating MIR balloons flown in 2001, 2003 and 2004. The analysis makes use of potential vorticity (PV) as proxy of horizontal transport, and the difference in altitude between the 340 and $370 \mathrm{~K}$ isentropic sur-
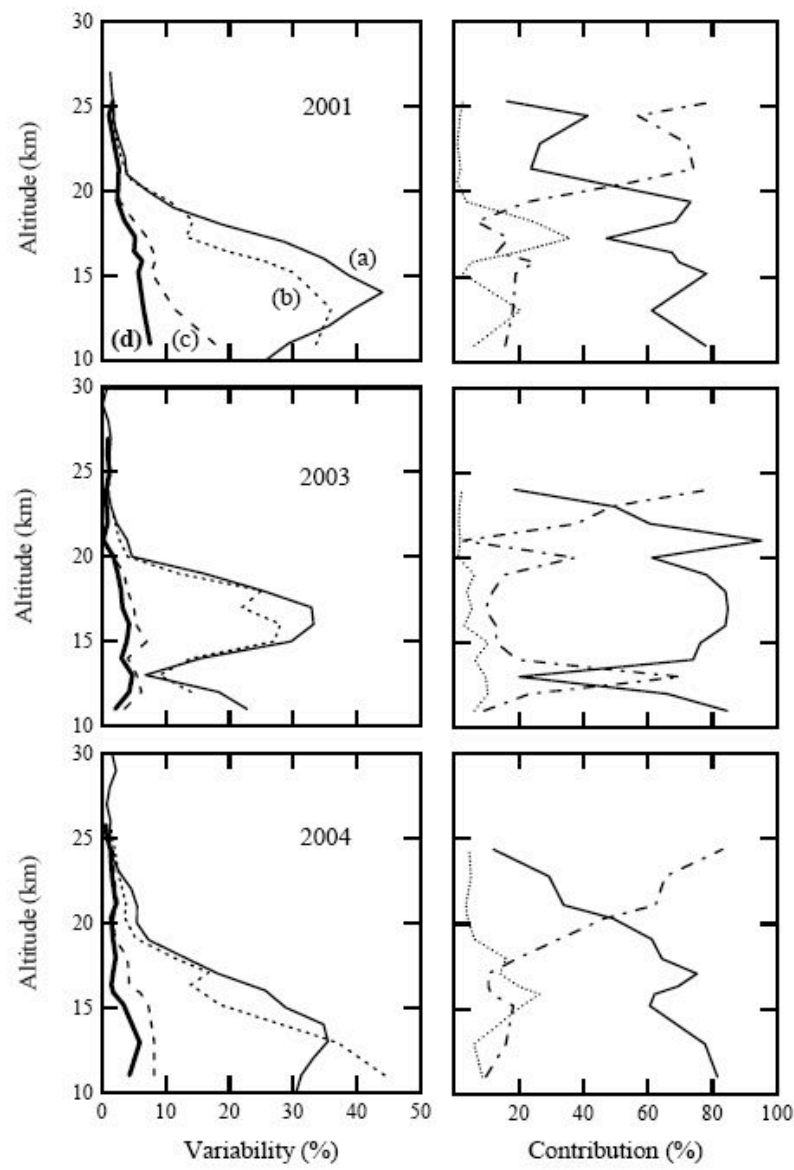

Fig. 15. Analysis of the contributions of meridional and horizontal transport to the ozone zonal variability (relative standard deviation) in 2001 (top), 2003 (middle) and 2004 (bottom). Left: number density variability (\%) at constant altitude (solid line a), mixing ratio on isentropic surfaces (dotted line b); after removing horizontal transport (dotted-dashed c); after removing vertical and horizontal transport (bold solid line d). Right: relative contributions of horizontal (solid line) and vertical (dotted) transport and measurement errors (dotted-dashed) to the total variability (Borchi et al., 2007).

faces as a proxy of convection. The first is provided by the MIMOSA contour advection model run every $5 \mathrm{~K}$ between $300 \mathrm{~K}$ and $700 \mathrm{~K}$ initialized by the 6-hourly ECMWF analyses (Hauchecorne et al., 2002), whereas the second is derived from the ECMWF vertical velocity. As shown in Fig. 15, the ozone concentration displays a maximum variability between $12-19 \mathrm{~km}$, mainly due to horizontal exchange with the midlatitudes (60-80\%), and to a lesser extent to vertical transport (20\%), although deep convective uplifting in the TTL is not represented in ECMWF analyses. After removing the influence of horizontal and vertical exchange, local photochemical production appears to contribute for only a small amount.

The possible contribution of convective lifting of tropospheric air in the TTL at the global scale was investigated 


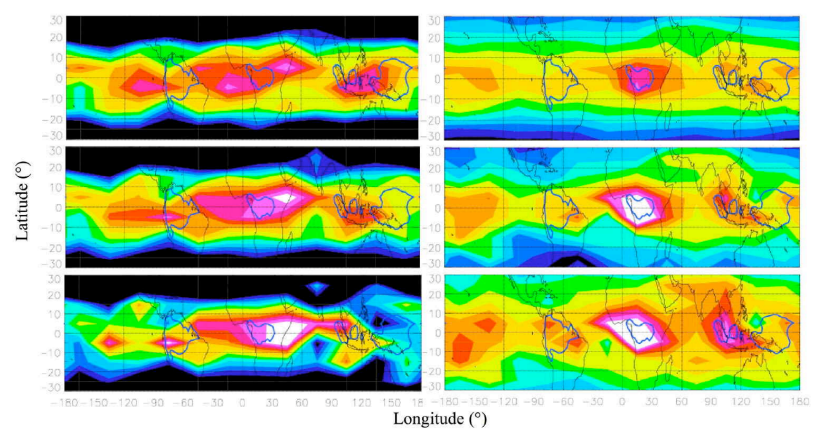

Fig. 16. 2002-2004 average $\mathrm{CH}_{4}$ HALOE (left) and $\mathrm{N}_{2} \mathrm{O}$ ODINSMR (right) zonal variation of concentration in the TTL in MarApr-May. Top: $19 \mathrm{~km}$, bottom: $17 \mathrm{~km}$, middle: interpolated at $400 \mathrm{~K}$ (Ricaud et al., 2007).

by Ricaud et al. (2007) from satellite measurements of tropospheric species above the tropopause. Figure 16 shows the mean $\mathrm{CH}_{4}$ and $\mathrm{N}_{2} \mathrm{O}$ concentrations at 17 and $19 \mathrm{~km}$ retrieved respectively by HALOE and ODIN-SMR (submillimetre microwave radiometer) in Mar-Apr-May 20022004. Systematic regional differences are seen with a prominent maximum over equatorial Africa and to a lesser degree over Central America, Southeast Asia and Indonesian island, in contrast to the West Pacific. The location of increased concentration of tropospheric species over continents coincides with that of the maximum of overshooting precipitation features (OPF) of the TRMM precipitation radar (Liu and Zipser, 2005; Zipser et al., 2006). Although meridional import of poorer $\mathrm{CH}_{4}$ and $\mathrm{N}_{2} \mathrm{O}$ stratospheric air from the mid-latitudes might also contribute, these observations suggest that convective overshooting over land might be a significant mechanism of vertical transport at the global scale in the TTL. In a further study of $\mathrm{N}_{2} \mathrm{O}$ in the UTLS, Ricaud et al. (2009) showed the existence of a systematic seasonal variation of maximum amplitude between 400-450 K ( 17.5$19 \mathrm{~km}$ ), not reproduced either by the MOCAGE (Modèle de Chimie Atmosphérique à Grande Echelle) CTM of MétéoFrance forced by ECMWF vertical velocity suggesting thus a vertical transport mechanism not included or underestimated in the models.

Modelling studies were also performed by Levine et al. $(2007,2008)$ to investigate the global structure of the TTL using both high-resolution trajectories and a lower-resolution CTM. In each case the regions of preferential transport from the lower troposphere into the TTL and from the TTL into the stratosphere were examined. The trajectories as well as the p-TOMCAT CTM model show much smaller regional differences in the transport from the TTL to the stratosphere than in the transport into the TTL from the lower levels, suggesting that the transport into the TTL would occur primarily over the maritime continent, followed by extensive horizontal transport within the TTL. Those conclusions are in con- tradiction with the above tropospheric tracers observations and with the heavier isotopic composition of water vapour in the lower stratosphere indicative of evaporation of convectively lofted ice crystals (Steinwagner et al., 2010). They contrast also the time-variation of stratospheric aerosols retrieved from the CALIPSO lidar (Vernier et al., 2009, 2011), showing a fast cleansing of the whole lower stratosphere up to $20 \mathrm{~km}$ during the Southern Hemisphere summer, indicative of clean tropospheric air fast lofting. As in the case of the simulation of tropospheric tracers, there is clear indication that, in contrast to non-hydrostatic mesoscale models, CTM or trajectory models forced by ECMWF fail to represent properly the fast troposphere-to-stratosphere transport associated with convection.

Another process that could be relevant to vertical transport in the UTLS is the generation of gravity waves by convective systems and their propagation into the stratosphere. This was studied using the meteorological parameters measured during the superpressure balloon (SBP) long-duration flights. Figure 17 shows for instance the horizontal kinetic energy spectra for two of the SPB flights (BP4 and BP6, Table 8). The energy is represented with respect to the intrinsic frequency, i.e., the frequency that is measured in the mean flow. The theory of gravity waves predicts that these motions have intrinsic frequencies larger than the inertial frequency, which depends on latitude. BP4 (black curve) stayed at low latitudes and a broad spectrum of inertia-gravity waves with intrinsic periods as long as $40 \mathrm{~h}$ are observed on this flight. On the other hand BP6 was pushed to the middle latitudes, and consequently, the mean inertial frequency during this flight is about half that of BP6 $(20 \mathrm{~h})$. These features, fully consistent with the theory, demonstrate the ability of SPB flights to resolve gravity-wave motions. Furthermore, in the highfrequency gravity-wave band, the picture clearly exhibits a slope of -2 , which seems to be a robust feature of gravitywave energy in the stratosphere (Hertzog et al., 2002). On the other hand, the low-frequency part of the spectra is likely associated with Rossby waves, which are more visible on the mid-latitude flight. However, further studies are still needed to investigate the variation of wave activity, identify the wave sources, and quantify the energy and momentum transported by the waves to the upper atmosphere. However, there is little evidence in those data of a significant contribution of gravity waves to the vertical transport across the tropopause.

\subsection{Evaluation of meteorological models temperature and wind analyses and re-analyses}

Among the HIBISCUS objectives in this field were (i) a comparison with temperature and winds from the ECMWF and NCEP operational models in the tropics, and (b) an independent evaluation of the long term temperature trend (of about $-0.5^{\circ} \mathrm{C}$ per decade) derived from radiosondes near the tropical tropopause (Seidel et al., 2001; Randel et al., 2000). These trends are themselves different from the trends 


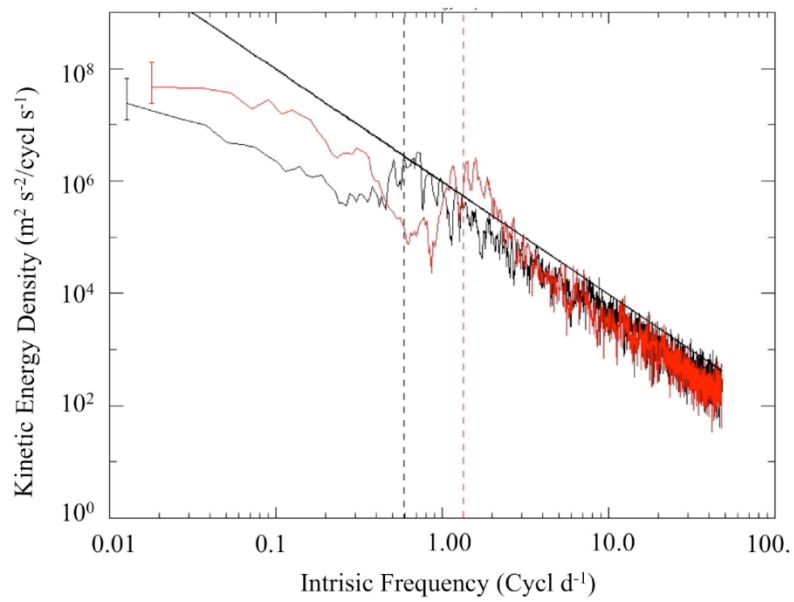

Fig. 17. Horizontal kinetic energy spectra obtained with SPB4 (black) and SPB6 (red) wind observations. The error bars on the left of the spectra show the $90 \%$ confidence level. The vertical dashed lines indicate the flight-averaged inertial frequencies. A -2 slope (thick black line) is shown for reference.

in ECMWF/ERA40 or NCEP/NCAR re-analyses showing show drops of various amplitude in the temperature data series (Randel et al., 2004). The first aim has been achieved by using the data of the HIBISCUS SPB and MIR long duration flights, whilst the second required an unprecedented search for past balloon flight data in the archives of the French laboratories.

Actual temperature, wind and trajectories of the 8 SPB and the 3 MIR balloons in 2004 have been compared by Knudsen et al. (2006) to ECMWF T511 and NCEP operational products. The ECMWF operational analysis were shown to display a systematic cold bias of $0.9 \mathrm{~K}$ and too strong easterly zonal winds by $0.7 \mathrm{~m} \mathrm{~s}^{-1}$, when compared to balloon measurements above the tropical tropopause between $50-80 \mathrm{hPa}$. The temperature bias revealed by the balloons is fully consistent with the $-1 \mathrm{~K}$ to $-2 \mathrm{~K}$ bias reported by Borsche et al. (2007) in the tropical tropopause region from temperature measurements by radio occultation of the CHAllenging Minisatellite Payload (CHAMP) satellite during the same period. The consistency between the two totally independent data sets confirms the cold bias in the ECMWF operational analysis in 2004.

Similarly, possible biases in the trends have been examined by comparison of the data of past CNES, LMD and Service d'Aéronomie long-duration balloon flights with the ERA40 re-analyses (Christensen et al., 2007). Found in the archives were the data of 30 MIRs and 3 SPBs of $10 \mathrm{~m} \mathrm{di-}$ ameter flown from Pretoria in South Africa in 1988-1992, Latacunga in Ecuador in 1994-1998, and Bauru in Brazil in 2000-2001. After careful check of the data quality by comparing measurements performed by independent instruments flown on the same balloon, about 40000 additional tem- perature and 12000 wind measurements of 18 MIRs and 3 SPB flights between 1988-2001 were successfully retrieved. Compared to the balloon data (Fig. 18), the ERA-40 (T159 $3-\mathrm{D}$ variational assimilation) temperatures in the tropical stratosphere show systematic time varying biases, decreasing from $+1.16 \mathrm{~K}$ in $1988-1989$ to $+0.26 \mathrm{~K}$ in $1994-1996$ and $-0.46 \mathrm{~K}$ after 1998 , the latter being fully consistent with the $-0.9 \mathrm{~K}$ difference between ECMWF operational analyses and the HIBISCUS flights and radio-occultation determinations in 2004. The time varying biases compared to the measurements of the long duration balloons are consistent with those derived by Randel et al. (2004) from radiosondes in 1991-2003. They confirm the erroneous faster cooling of ERA-40 compared to the sondes, likely caused by errors in the series of Stratospheric Sounding Unit (SSU), Microwave Sounding Units (MSU) and Advanced Microwave Sounding Units (AMSU) satellite temperature retrievals assimilated in the model.

Following a similar approach Hertzog et al. (2006) have compared the ERA40 reanalysis at $200 \mathrm{hPa}$ in the Southern Hemisphere with the data of the 480 small super-pressure balloons of $3.70 \mathrm{~m}$ diameter at $200 \mathrm{hPa}$ launched by the CNES for the EOLE experiment in 1971-1972. The data, surprisingly absent in the French institutes archives, were recovered at NCAR. As many as 80000 reliable temperature and wind data in one year, have been recovered, providing information on atmospheric regions scarcely sampled during the pre-satellite era, i.e. the Antarctic and Southern Hemisphere oceans. When compared to the EOLE dataset, the ECMWF ERA-40 re-analyses show limited temperature bias at $200 \mathrm{hPa}$ in sub-polar regions, whilst the NCAR NN50 is a few degrees colder. However, both reanalysis are found warmer by about $1 \mathrm{~K}$ in the subtropics. The biases on the wind field are very small, or not significant. The standard deviation of the difference between models and balloons data was shown to improve over continents compared to oceanic areas, illustrating the heterogeneity of atmospheric observations during the pre-satellite era, emphasizing the difficulty for atmospheric models to capture synoptic systems in the poorly sampled Southern Hemisphere by that time. However, the two reanalyses perform differently in this respect. The NCEP/NCAR standard deviations were shown to be significantly smaller than those of ERA40.

\subsection{Satellite validation}

Remote observations of atmospheric species available from space instruments employing a range of techniques were available. However, significant discrepancies are often observed between them, particularly in the tropical UT/LS, where the quality of the retrievals degrades rapidly at decreasing altitude, because of the presence of high-altitude clouds, low temperature, interference with water vapour, etc. A number of space instruments were in operation during the HIBISCUS period: the long-standing NASA SAGE 


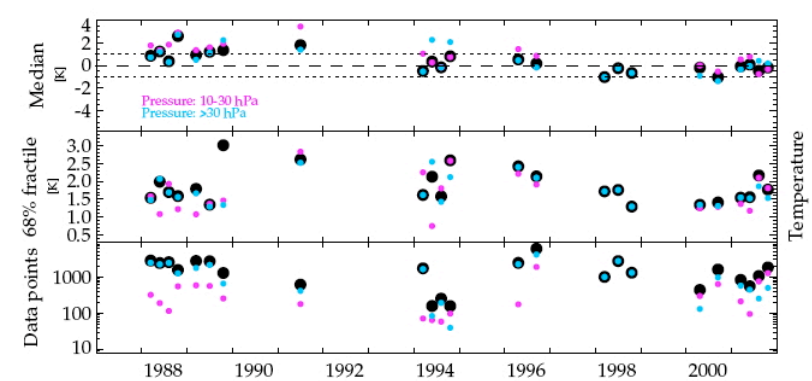

Fig. 18. Past long-duration balloon temperature measurements in the tropical lower stratosphere compared to ECMWF/ERA40. Top: difference ERA40-ballon in K; middle: standard deviation; bottom: data points number. A systematic bias is observed, ERA40 being warmer by $1.16 \mathrm{~K}$ in $1988-1989$, by $0.26 \mathrm{~K}$ in $1994-1996$, and then cooler by $0.46 \mathrm{~K}$ after 1998 (Christensen et al., 2007).

II and HALOE, the Sweden-Finland-Canada-France ODIN OSIRIS (Optical Spectrograph and InfraRed Imaging System) and SMR, and the ESA ENVISAT MIPAS, GOMOS and SCIAMACHY (Scanning Imaging Absorption Spectrometer for Atmospheric CHartographY). Unfortunately the launch of NASA AURA in the A-Train initially planned before the campaign was delayed and no direct comparisons with MLS could be performed. Among the species, HIBISCUS provided a unique data set of ozone, water vapour, bromine oxide, nitrous and nitrogen oxides in the tropics used and still in use for evaluating the performances of the above satellite instruments retrievals.

\subsubsection{Ozone}

The measurements of short duration balloons have been used for several punctual validations (e.g. for ODIN-OSIRIS by Jegou et al., 2008). More effective for assessing the performance of the satellites, is the statistical approach used by Borchi et al. $(2005,2007)$ using the large number of profiles of the long duration balloons. Based on the small $(<2 \%)$ ozone variability in the tropical stratosphere above $20 \mathrm{~km}$, an original statistical approach was developed. It consists in comparing the zonal mean profiles, indicative of biases in altitude registration and of systematic errors, and their variability (standard deviation compared to the mean), indicative of the random error of each instrument. Using this technique, the MIR flights data were compared with all the satellite ozone profiles available in the tropics. As an example, Fig. 19 shows the evaluation of HALOE measurements. Systematic altitude shifts could be observed in some satellite profiles, varying from $<50 \mathrm{~m}$ for the GOMOS stellar occultation instrument, followed by $+100 / 200 \mathrm{~m}$ for solar occultation systems (SAGE II, HALOE above $22 \mathrm{~km}$ ), but as large as $-900 \mathrm{~m}$ or $+2000 \mathrm{~m}$ for limb viewing systems (OSIRIS, SCIAMACHY). The ozone relative biases are generally smaller than $\pm 4 \%$, for measurements in the visi-

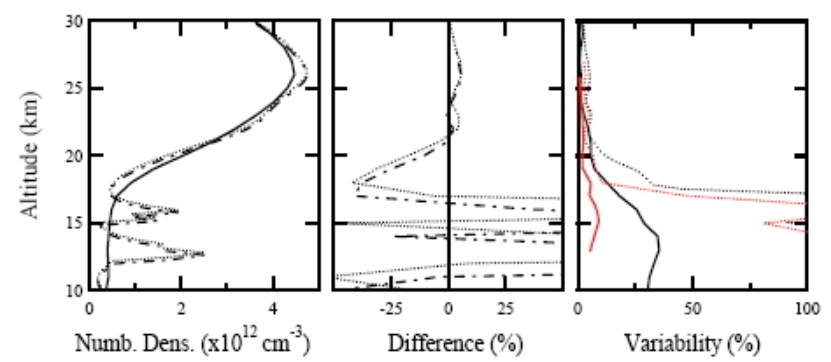

Fig. 19. Example of evaluation of HALOE satellite ozone measurements precision by comparison with SAOZ long duration balloon profiles. Solid line: SAOZ; dotted: HALOE v19; dotted-dashed: HALOE altitude adjusted. From left to right: mean zonal profiles, relative percent difference and relative percent standard deviation before (black) and after (red) removal of horizontal transport. Above $20 \mathrm{~km}$, the relative bias between HALOE and SAOZ is $<4 \%$ and the HALOE precision better than $3 \%$. At lower altitude, the bias increases rapidly due to an altitude registration error in HALOE (Borchi et al., 2007).

ble Chappuis bands (SAGE II and III, GOMOS above $22 \mathrm{~km}$ and OSIRIS), the near IR HALOE above $22 \mathrm{~km}$ and the ozonesondes, but increasing to $+7 \%$ in UV SCIAMACHY and in the mid-IR MIPAS and the sub-millimetre ODINSMR limb viewing systems. Regarding precision, the best measurements are found to be those of SAGE II (2\%), followed by HALOE above $22 \mathrm{~km}$ (3-4\%), ozonesondes, SAGE III and OSIRIS ( $\sim 5 \%)$, GOMOS above $22 \mathrm{~km}$ and SCIAMACHY ( 6\%), MIPAS (8.5\%) and finally SMR (16\%). Overall, satellite ozone measurements do not appear reliable below $20 \mathrm{~km}$ in the tropics, except those of SAGE II (and possibly SAGE III), even though biased low by $50 \%$ and of limited precision.

\subsubsection{Nitrous oxide}

On 18 February 2003, the DIRAC gas chromatograph was flown from Bauru in whole air sampling mode (no adsorbent trap). This enabled a vertical profile of $\mathrm{N}_{2} \mathrm{O}$ to be measured. The $\mathrm{N}_{2} \mathrm{O}$ profile has been used as part of the Odin/SMR satellite validation for which $\mathrm{N}_{2} \mathrm{O}$ is a target gas (Urban et al., 2005). The $\mathrm{N}_{2} \mathrm{O}$ profiles were within the instrument uncertainties over all altitudes available for comparison, with the exception of the 23 to $26 \mathrm{~km}$ region, where the DIRAC $\mathrm{N}_{2} \mathrm{O}$ observations were significantly lower than those from Odin/SMR. The difference was ascribed to horizontal variability in the Bauru region.

\subsubsection{Water vapour}

The water vapour profiles provided by GOMOS, MIPAS, HALOE, SAGE II and AIRS between $11-26 \mathrm{~km}$ in the UT/LS have been compared to those of the two in situ hygrometers, the $\mu$ SDLA diode laser and the surface acoustic 
wave, as well as the remote SAOZ MIR long duration measurements. Using the same statistical method employed for ozone, Montoux et al. (2009) (Fig. 20) showed that in the stratosphere, above $20 \mathrm{~km}$, HALOE displays the best precision (2.5\%), followed by SAGE II (7\%), MIPAS (10\%), SAOZ (20-25\%), GOMOS (25\%) and SCIAMACHY (35\%). In reference to HALOE, the biases are little significant, not exceeding $10 \%$ except SCIAMACHY drier by $20 \%$ and GOMOS displaying a positive gradient in contrast to all others. The comparison degrades below $20 \mathrm{~km}$, where the precision of all satellites decreases rapidly, and large biases are reported, HALOE and SAGE II (adjusted to HALOE) being drier by up to 2 ppm compared to the 4$5 \mathrm{ppm}$ of the in situ hygrometers. The situation is even worse below $16 \mathrm{~km}$ in the lower stratosphere, where satellite measurements do not appear reliable compared to in situ and remote balloon profiles, with the exception of AIRS agreeing within $25 \%$ with the balloon data. As for ozone, those results demonstrate the quality of satellite remote water vapour measurements in the stratosphere, but also the difficulty to retrieve accurate information below $20 \mathrm{~km}$ in the Tropical Tropopause Layer.

\subsubsection{Bromine oxide}

The SAOZ UV extended version $\mathrm{BrO}$ profiles recorded in 2003 and 2004 constitute a unique data set for validating satellite measurements in the tropics. They were used to validate the SCIAMACHY limb retrievals of the Harvard Smithsonian Center for Astrophysics (Sioris et al., 2006), of the Universities of Heidelberg and Bremen (Dorf et al., 2006; Rozanov et al., 2010), as well as those of OSIRIS-ODIN (McLinden et al., 2010). They also provided a unique reference for retrieving profiles from ground-based column measurements at Reunion Island at the same latitude (Theys et al., 2007). Overall, after compensation for the BrO photochemical change between the time of the satellite overpasses and the balloon flights in late afternoon. Satellite-retrieved and balloon profiles are found consistent within $\pm 20 \%$ in the stratosphere.

\subsubsection{Nitrogen dioxide}

The unique set of $\mathrm{SAOZ}$ tropical $\mathrm{NO}_{2}$ profiles recorded during the HIBISCUS campaigns has been used for direct comparisons with satellite retrievals (e.g. with those of MIPAS, Wetzel et al., 2007) and for converting the sunset/sunrise measurements of the NDACC ground-based SAOZ in the tropics into vertical columns for comparisons with GOME, SCIAMACHY, OMI and METOP-GOME2 (e.g. Hendrick et al., 2004; Lambert et al., 2006, 2007; Celarier et al., 2008).
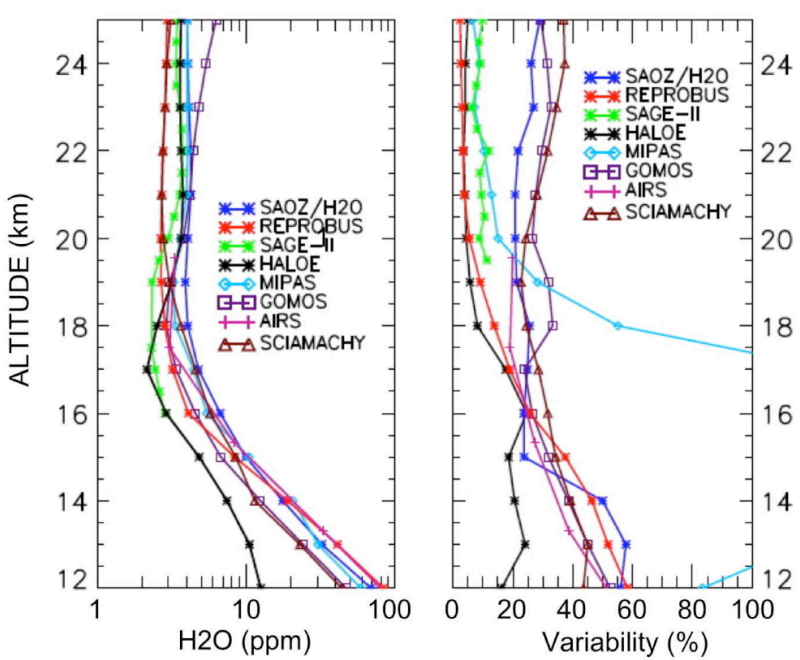

Fig. 20. Similar analysis of water vapour profiles. Above $20 \mathrm{~km}$, all measurements are consistent within their quoted accuracy, with the exception of GOMOS showing a mixing ratio increasing with altitude. SAGE II, HALOE and MIPAS display the best precision. The REPROBUS/ECMWF model underestimates the mean water vapour mixing ratio as well as its variability. The measurements degrade below where HALOE displays a systematic low bias like that of ozone and MIPAS a fast decrease of precision. At these altitudes best measurements are those of AIRS (Montoux et al., 2009).

\section{Summary}

Significant progress has been achieved within the HIBISCUS project in the understanding of mechanisms involved in the tropical UTLS dynamics, microphysics and chemistry, the representation of temperature and wind in the global meteorological analyses and reanalyses, and the assessment of the performances of several satellite retrievals in the tropics.

Overall, the composition of the UTLS, the region between 14 and $20 \mathrm{~km}$ of intermediate lapse rate between the almost adiabatic upper troposphere and the stable stratosphere, appears highly variable. Among the newest results is the observation of strong local episodic updraughts of cold air, tropospheric chemical tracers, low ozone and ice particles, across the lapse rate tropopause at about $15-16 \mathrm{~km}$. These events reached up to 18 or $19 \mathrm{~km}(420-440 \mathrm{~K})$ over the convectively active region of South-eastern Brazil in the summer, demonstrating the local impact of the frequent occurrence of injections of tropospheric air in the lower stratosphere by overshooting towers. The events are shown to result in a hydration of lower stratosphere by geyser-like injection of ice crystals across the tropopause. The contrast between the composition of the lower stratosphere over land and oceanic areas in the same latitude range, reported by the circum-navigating balloons and satellites, indicate that these events might have a significant impact at the global scale. However, although well represented locally 
by meso-scale non-hydrostatic models, the signature of such events at the global scale is shown not captured by global Chemistry-Transport Models (CTM) models forced by Numerical Weather Prediction (NWP), which instead show a slow vertical lofting over the West Pacific in contradiction with our observations.

The comparison of temperature measured by the HIBISCUS long-duration balloons and a number of similar flights carried in the tropics by French laboratories since 1988, indicates a systematic time varying bias in NWP models analysis and reanalysis, similar to that observed with the radiosondes, likely coming from errors in the assimilated Stratospheric Sounding Unit (SSU), Microwave Sounding Units (MSU) and Advanced Microwave Sounding Units (AMSU) satellite temperature retrievals. Finally, the data of chemical species collected by the HIBISCUS balloons have allowed a thorough evaluation of satellite measurements performances in the tropics, particularly of ozone, nitrogen oxide, water vapour and bromine oxide, whose data are made available for checking the progress of further retrieval versions in the ETHER French database at (http://ether.ipsl.jussieu.fr).

\section{Appendix A}

\section{Short-duration balloon instruments}

\section{A1 In situ sensors}

\section{A1.1 DIRAC gas chromatograph}

DIRAC (Determination In situ by Rapid Analytical Chromatography) is a lightweight gas chromatograph developed by the University of Cambridge (Robinson et al., 2000; Gostlow et al., 2010). The overall instrument weight for an 8-h flight is $30 \mathrm{~kg}$. DIRAC uses a Carboxen adsorbent to preconcentrate samples of known volume before injection onto a separation column and electron capture detector. It measures a range of halocarbons at a time resolution, which can be adjusted depending on the type of flight being made. For instance, CFC-11 and CFC-113 can be measured at 100-s intervals $(0.3-0.7 \mathrm{~km}$ resolution depending on balloon vertical velocity) or CFC-11, CFC-113, $\mathrm{CHCl}_{3}, \mathrm{CH}_{3} \mathrm{CCl}_{3}$ and $\mathrm{CCl}_{4}$ can be measured at 200 -s intervals $(0.6-1.4 \mathrm{~km}$ resolution). It has been successfully deployed on 10 balloon flights including 4 flights during THESEO 1999/2000. The repeatability of standard gas measurements during flight (1 sigma in-flight precision) is $6.5 \%$ for CFC- $11,7.5 \%$ for $\mathrm{CCl}_{4}, 10 \%$ for $\mathrm{CH}_{3} \mathrm{CCl}_{3}$ and $15 \%$ for $\mathrm{CHCl}_{3}$.

\section{A1.2 DESCARTES grab sampler}

DESCARTES (Détermination et Séparation par Chromatographie lors de l'Analyse des Résultats des Traceurs Echantillonnés dans la Stratosphère) is a lightweight (17 kg) balloon-borne grab sampler, also developed by the University of Cambridge, in which known volumes of stratospheric air are trapped on sample tubes containing Carboxen. A range of halocarbons (typically 10 compounds) is subsequently measured in the laboratory using a gas chromatograph and electron capture detector. The instrument carries 16 adsorbent tubes, which limits the number of samples, which can be taken per flight. For a detailed discussion see Danis et al. (2000). It has been successfully deployed on over 20 flights since 1995. The measurement precision (1 sigma) is $3 \%$ for CFC-11, $1.5 \%$ for CFC-113, $16 \%$ for $\mathrm{CCl}_{4}, 5.5 \%$ for $\mathrm{CH}_{3} \mathrm{CCl}_{3}$ and $6.5 \%$ for $\mathrm{CHCl}_{3}$.

\section{A1.3 Micro-SDLA tuneable laser}

The $\mu$ SDLA (Micro Spectrometric Diode Laser) sensor of CNRS-SA is a diode laser spectrometer devoted to the in situ measurement of $\mathrm{H}_{2} \mathrm{O}$ and $\mathrm{CH}_{4}$ in the UTLS by infrared absorption spectroscopy (Durry et al., 2004). Three near-infrared telecommunication-type InGaAs laser diodes are connected by means of optical fibers to an open multipath optical cell providing an absorption path-length of $28 \mathrm{~m}$. The laser beam is absorbed by ambient gas molecules as it is bouncing back and forth between the cell mirrors. $\mathrm{CH}_{4}$ is monitored at $1.65 \mu \mathrm{m}$ and $\mathrm{H}_{2} \mathrm{O}$ at $1.39 \mu \mathrm{m}$ using the differential detection technique. The payload also includes pressure and temperature sensors. An accuracy of 5\% is achieved for a measurement duration of $160 \mathrm{~ms}$. To avoid contamination by out-gassing from the balloon or the payload, only data recorded during the slow night-time descent of the balloons are considered in the TTL and the UT, continued by those during parachute descent in the lower troposphere.

\section{A1.4 TDLAS tunable laser}

The lightweight Tunable Diode Laser (TDLAS) of the National Physical Laboratory (NPL) uses near-infrared tunable diode lasers and an astigmatic Herriott cell to measure spectroscopic absorption over a pathlength of up to $101 \mathrm{~m}$. The instrument has been used for fast response measurements of atmospheric tracers on board balloons (van Aalst et al., 2004) and aircraft (Bradshfaw et al., 2002). The instrument was configured for water vapour measurements during HIBISCUS, using an all-metal gondola designed to minimise out-gassing. The measurements were made at a frequency of $0.7 \mathrm{~Hz}$ over three water vapour absorption lines around $1.36 \mu \mathrm{m}$ which had a range of line strengths to cover the wide atmospheric concentration range. Analysis was carried out using parameters from the Hitran 2004 spectroscopic database, and the results had an estimated uncertainty of $10 \%$, with a detection limit of $0.5 \mathrm{ppm}$.

\section{A1.5 Surface Acoustic Wave (SAW) $\mathrm{H}_{2} \mathrm{O}$ sensor}

Frost point hygrometry is a well-established measurement method, with most current instruments using a cooled mirror 
with an optical source and detector as the sensing element. The instrument of the University of Cambridge is based on this method, but uses a surface acoustic wave (SAW) crystal instead for detection (Hansford et al., 2006). The advantage of the SAW method is that fewer monolayers can be detected, therefore being intrinsically more sensitive and has a much faster response relative to a standard mirror frost point hygrometer. An alternating voltage across interdigital electrodes on the surface of the SAW crystal causes oscillations at a well-defined frequency (typically $100 \mathrm{~s}$ of MHz). The SAW crystal is placed, together with an accurate platinum resistance thermometer, onto a Peltier cooler. When cooled to the frost point, water vapour condenses onto the SAW surface, reducing the SAW oscillation frequency and amplitude, forming the basis of a feedback circuit. The temperature at which condensation occurs is then related to the ambient water vapour amount. A prototype, weighing less than $3 \mathrm{~kg}$ has been flown on several occasions, measuring frost points below $-80^{\circ} \mathrm{C}$.

\section{A1.6 Solid State Ozone Sensor (SSS O $\left.\mathrm{O}_{3}\right)$}

The sensor, based on a commercial sensing element also developed by the University of Cambridge, consists of a thin metal oxide (tungsten oxide) layer mounted on a small $(2 \mathrm{~mm} \times 2 \mathrm{~mm})$ ceramic tile (Hansford et al., 2005). The principle of operation is that when heated to its operating temperature, oxygen vacancies, formed thermally at the oxide surface, create electron donor states, resulting in an increase in charge carrier concentration (i.e., a reduction in resistance). $\mathrm{O}_{3}$ molecules react on the oxide surface filling the oxygen vacancies, decreasing the charge carrier concentration. The resulting increase in electrical resistance, which can be related to $\mathrm{O}_{3}$ concentration, is then measured. The device has sensitivity to better than $3 \times 10^{10}$ molecules $\mathrm{cm}^{-3}$, corresponding to $0.03 \mathrm{ppm}$ at $50 \mathrm{hPa}$. The typical time response of the device is in the order of a few seconds. Its weight is less than $0.5 \mathrm{~kg}$, excluding batteries.

\section{A1.7 LABS backscatter diode laser}

This instrument developed by the Italian Consiglio Nazionale delle Ricerche Istituto di Scienze dell'Atmosfera e del Clima (CNR-ISAC) and Ente Nazionale per le Nuove tecnologie, l'Energia e l'Ambiente (ENEA) (Adriani et al., 1999) provides an in-situ measurement of the aerosol volume backscatter coefficient and aerosol depolarization at $532 \mathrm{~nm}$. The aerosol volume backscatter coefficient detects the presence of aerosols in the air mass sampled, as well as a rough estimation of their quantity. The aerosol depolarization, being the ratio to what extent the main polarization of the laser is preserved in the backscattering process, gives information on the shape of the particles, and in some cases a coarse estimation of their dimensions as well (Buontempo et al., 2006).

\section{A1.8 Lightweight scattering probe}

This instrument of the University of Manchester (UMIST) was designed to measure the number size distribution of aerosol particles in the size range 0.3 to $3 \mu \mathrm{m}$ diameter using light scattering. The instrument uses a white light source and measures the scattered light intensity at 45 and 90 degrees scattering angle, using dual detectors. One of each of the pair of detectors was fitted with a polarising filter to distinguish between spherical liquid droplets and solid crystals. HIBISCUS provided the first test for this instrument and whilst it flew during the experiment, a critical failure occurred and no data could be retrieved.

\section{A1.9 AIRS electric field probe}

The AIRS electric field instrument of CNRS-CETP (Centre d'Etude des Environnements Terrestre et Planétaires) is designed to measure the vertical component of the atmospheric electric field from DC to $10 \mathrm{kHz}$ and the electric conductivity of the atmosphere through the relaxation technique. It uses the double probe technique with 2 carbon coated cylindrical electrodes, $3 \mathrm{~cm}$ in diameter and $15 \mathrm{~cm}$ long, installed at the ends of a vertical boom, $1 \mathrm{~m}$ in length, located $25 \mathrm{~cm}$ away from the gondola. Grounded plates, also coated with carbon, are installed on the sides of the gondola. They provide a good electrical contact between the electronics ground and the local ionized atmosphere and avoid the detrimental influence of spurious potentials that may arise on the external insulating material of the gondola. High impedance, very low leakage current preamplifiers allow to perform measurements in the low conductivity atmosphere down to a few kilometre altitudes. Data are recorded in 2 channels, one for large amplitude signals, up to $\pm 200 \mathrm{~V} \mathrm{~m}^{-1}$, from DC to $\sim 2 \mathrm{kHz}$ with a resolution of $4 \mathrm{mV} \mathrm{m}^{-1}$ and the second one for low amplitude AC signals from $\sim \mathrm{Hz}$ to $10 \mathrm{kHz}$ with a sensitivity of $\sim 2$ to $3 \mu \mathrm{V} \mathrm{m}^{-1} \mathrm{~Hz}^{1 / 2}$.

\section{A2 Remote sensors}

\section{A2.1 SAOZ UV-Visible spectrometer}

The SAOZ of Service d'Aéronomie of the Centre National de la Recherche Scientifique (CNRS-SA) is a UV-Vis spectrometer for remote measurement by solar occultation during the ascent of the balloon in the late afternoon and at sunset or sunrise from float altitude. Three versions have been deployed during HIBISCUS: the basic SAOZ in the 300 $650 \mathrm{~nm}$ spectral region for $\mathrm{O}_{3}$ (2\% accuracy), $\mathrm{NO}_{2}(5 \%)$, and cloud extinction (Pommereau and Piquard, 1994), a UV enhanced version in the $300-400 \mathrm{~nm}$ range, SAOZ-BrO, for $\mathrm{BrO}(15 \%)$ (Pundt et al., 2002), and a newly developed 400 $1000 \mathrm{~nm}$ version for the measurement of $\mathrm{H}_{2} \mathrm{O}$ in addition to $\mathrm{O}_{3}$ and $\mathrm{NO}_{2}$. The $\mathrm{SAOZ}$ payload weighs $18 \mathrm{~kg}$. 


\section{A2.2 NILUCUBE UV radiometer}

A new version of the NILUCUBE instrument of the Norwegian Institute for Air Research (NILU) described by Kylling et al. (2003) was developed for HIBISCUS. The new sensor has six channels in each of its six heads. The heads are mounted on the faces of a cube. For each head UV radiation is measured at 312 and $340 \mathrm{~nm}$, with a bandwidth of $10 \mathrm{~nm}$ at FWHM. In addition to radiation measurements, the new NILUCUBE includes a GPS for position and timing information, and a magnetic compass for tilt, roll and heading information. The temperature is measured for each of the six heads. Data from all sources are sampled every second. The weight of the instrument is about $6 \mathrm{~kg}$. Each head measures the irradiance. The new NILUCUBE has had improved input optics which deviates less than 5\% from the ideal cosine response for zenith angles smaller than $85^{\circ}$. By combining the measurements from all heads, the actinic flux may be derived as shown by Kylling et al. (2003).

\section{A2.3 MULID micro-lidar}

This lightweight low-power micro-lidar of ENEA and CNRISAC employs a miniaturized Nd-YAG pulsed laser firing at $532 \mathrm{~nm}$ for measuring profiles of aerosol backscatter and depolarization during night time, from the altitude of the payload downward to the ground, with a vertical resolution of $30 \mathrm{~m}$ and a time resolution of $60 \mathrm{~s}$. In daylight conditions, the system was unable to provide profile information but operates as a near-range backscattersonde, providing values of backscatter and depolarization at a few tens of metres from the platform. The parameters obtained by MULID observations are, apart from intensity and depolarization profiles of the backscattered signal, also the extinction profile in optically thin clouds and cloud top height for optically thick clouds (Di Donfrancesco et al., 2006).

\section{A2.4 Lightning optical sensor}

This sensor developed by CNRS-SA was designed for detecting lightning and blue-jets flashes. The sensor is made of two photodiodes and amplifiers mounted, the first looking downward within a $180^{\circ} \mathrm{FOV}$ and the second upward within a $30-80^{\circ}$ annular FOV to avoid reflection of lightning flashes on the balloon or pieces of the payload.

\section{A3 Radiosondes equipment}

The Backscatter sondes operated by the Danish Meteorological Institute are backscatter sonde manufactured by the University of Wyoming (Rosen and Kjome, 1991) made of a xenon lamp, which emits a white flash every $7 \mathrm{~s}$. The light is scattered by particles and molecules in front of the sonde, and monitored with two photodiodes at 480 and $940 \mathrm{~nm}$, respectively. Two parameters are calculated from this signal: the backscatter ratio $(\mathrm{BR})$, i.e. the ratio between parti- cle and molecule backscatter, and the color index, defined as (BR940/BR480). The color index is correlated with the particle size. The ozone sondes also operated by the Danish Meteorological Institute are commercial Electro-Chemical Cells (ECC) from EN-SCI.

\section{Appendix B}

\section{Details of the meteorology of the short-duration flights performed in January-February 2004}

\section{B1 ZL balloon flights}

The ZLs were used for in-situ measurements of aerosol (LABS) or $\mathrm{N}_{2} \mathrm{O}$ (DIRAC) during the ascent/descent of the balloon, together with $\mathrm{O}_{3}, \mathrm{NO}_{2}, \mathrm{BrO}$ profile measurements by solar occultation during ascent and sunset period from float altitude, using both the SAOZ spectrometer and its UV extended version. Two flights were carried out, one on 31 January (ZL2) at 17:30 LT and the other on 5 February (ZL1) at 17:00 LT. Unfortunately, the DIRAC payload on ZL2 hit the ground during launch operation. Therefore no $\mathrm{N}_{2} \mathrm{O}$ profile was available in 2004 (but in 2003). All other instruments performed well. The two flights were performed in the SACZ, with ZL2 being in conditions almost unaffected by nearby convection (Fig. B1, left) and within an episode of mid-latitude air advection in the lower stratosphere, but the second (ZL1) during a much more active period, with an intense mesoscale convective system (MCS) of some $300 \mathrm{~km}$ extent, about $150 \mathrm{~km}$ to the south and south-west, as shown by the radar image (Fig. B1, right) and therefore a cooler TTL (minimum temperature of $-85^{\circ} \mathrm{C}$, instead of $-77^{\circ} \mathrm{C}$ ). Both LABS and SAOZ reported clouds up to $12 \mathrm{~km}$ on 31 January. Higher clouds were seen by SAOZ on 5 February when the atmosphere became totally opaque below $16.5 \mathrm{~km}$ in the direction of the sun at sunset. Relatively strong lightning activity was reported by the RINDAT network, peaking in both cases at some 200 flashes per hour in a $1^{\circ} \times 1^{\circ}$ area around 18:00 LT near Bauru.

\section{B2 SF balloon flights}

Launched in the late afternoon, these balloons are left descending very slowly $\left(0.5 \mathrm{~m} \mathrm{~s}^{-1}\right.$ or less) after their cooling at night for exploring the TTL and the UT down to $12-14 \mathrm{~km}$. The idea, tested first in 2003, proved to be excellent. Four flights were performed, with all four having slow descents of 3 to $5 \mathrm{~h}$.

In all cases (Table 6), they were carrying a tuneable diode laser, one or two hygrometers, a tracer-measuring instrument and a cloud detecting sensor, and an $\mathrm{O}_{3}$ high-resolution SSS sensor. Finally, the electric field instrument was flown together with the lightning optical sensors. In addition, all SF flights were accompanied by backscatter and/or ozonesondes, launched around 22:00 LT in the evening, because of the 

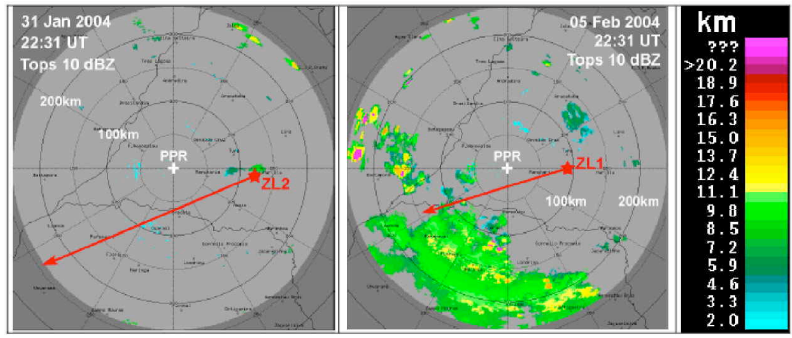

Fig. B1. Echo tops (reflectivity threshold $10 \mathrm{dBZ}$ ) seen by the SBand radar at Presidente Prudente (PPR) during the ZL flights. A star represents the balloon location at the time of the radar image and the tip of the arrow indicates the tangent point. Left: ZL2 at 22:31 UT, $2 \mathrm{~h}$ after launch, on 31 January. The IPMet radars of BRU and PPR detected isolated intense storm cells about $200 \mathrm{~km}$ north to north-east of the balloon position, topping up to $15 \mathrm{~km}$. Right: ZL1 at sunset at 22:31 UT on 5 February, about 150 min after its launch. The radar image displays a MCS of $300 \mathrm{~km}$ extension south to south-west of the flight track, topping at $11-12 \mathrm{~km}$ on average, with turrets (red dots) as high as $17-18 \mathrm{~km}$. SAOZ indicates an increase of extinction below $17 \mathrm{~km}$ (cirrus), the atmosphere becoming opaque below $16.5 \mathrm{~km}$ at sunset in the direction of the sun (arrow)

daytime restriction of the optical measurements. Two noontime NILUCUBE flights were also performed during the period, the first, on 13 February in almost cloud-free conditions and the second, on 25 February, on a more convectively active day, when high-altitude clouds where developing around noon.

\section{B2.1 SF-2 flight}

The balloon was launched on 13 February at 17:18 LT some $300 \mathrm{~km}$ east of a strong convective region over the west of the State of São Paulo, Mato Grosso do Sul and Paraguay (Fig. B2). The balloon reached an altitude of $20 \mathrm{~km}$ just before sunset, followed by a 3-h nighttime descent down to $11.8 \mathrm{~km}$, where it was cut down $90 \mathrm{~km}$ north of Bauru. From 11:00 LT (14:00 UT) on that day, convective systems began developing in the southeastern quadrant of the Bauru radar, rapidly intensifying during the early afternoon, later also in the southwest sector and east north east of the radar. At the time of the launch, the nearest storm was about $60-70 \mathrm{~km}$ southeast, but remained more or less stationary and at no stage did it impact on the flight trajectory. However, at the same time, the PPR radar showed a large area of instability moving in from northwest and west, but it never came closer than $300 \mathrm{~km}$ from the balloon track (Fig. B3). Towards the end of the flight, some very small $(5-10 \mathrm{~km})$ cells appeared just west of the floating balloon, but their tops stayed well below $10 \mathrm{~km}$. The radiosonde profile displays a fast change in lapse rate at $14 \mathrm{~km}$, sometimes called secondary tropopause, a minimum temperature of $-75.2^{\circ} \mathrm{C}$ at $15.7 \mathrm{~km}(115 \mathrm{hPa}$,

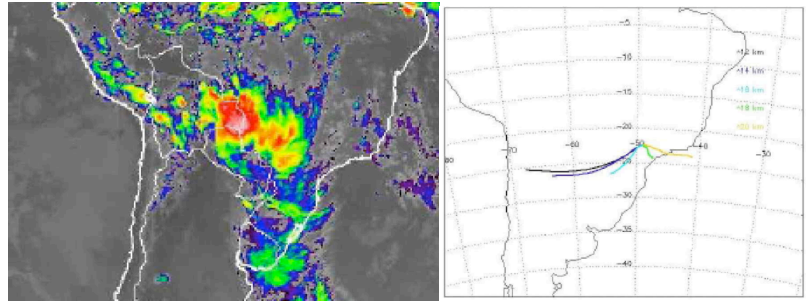

Fig. B2. SF-2 flight on 13 February. Left GOES-E image at 19:15 LT. Right: BRAMS one day 3-D backward trajectories ending at 18:00 UT at $12 \mathrm{~km}$ (black), $14 \mathrm{~km}$ (blue), $16 \mathrm{~km}$ (cyan), $18 \mathrm{~km}$ (green) and $20 \mathrm{~km}$ (yellow).

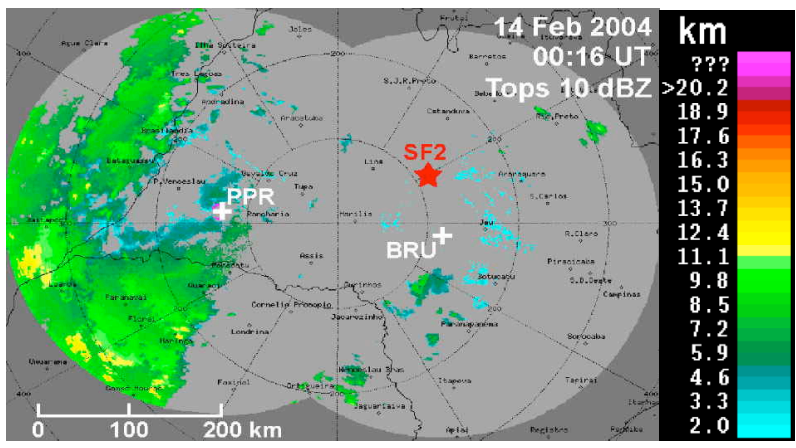

Fig. B3. Echo tops (reflectivity threshold $10 \mathrm{dBZ}$ ) observed by the Bauru and Presidente Prudente Radars on 13 February approximately four hours after launch. A star shows the SF2 flight location.

$367 \mathrm{~K}$ ), topped by an almost isothermal layer reaching up to $20 \mathrm{~km}$. Tropospheric winds were from south-westerly directions up to $15-16 \mathrm{~km}$, originating from a combination of the approaching tropical convective system over Mato Grosso do Sul and the warm front over Paraná, ahead of a cold front slowly propagating north-eastwards. The winds backed to easterly above the tropopause.

The SF2 balloon was carrying the DESCARTES halocarbon grab sampler with which six samples were taken during the ascent. But unfortunately, a power failure at float prevented sampling during the slow descent. The measurements of halocarbons across the tropical tropopause indicate a tracer concentration gradient in proportion to lifetime. The fast response $\mathrm{O}_{3}$ SSS produced good data during ascent and descent, showing an ozonopause at about the secondary tropopause around $14 \mathrm{~km}$, as well as resolved smallscale vertical structures. The $\mu$ SDLA tuneable laser provided methane and water vapour data throughout the flight. In the water vapour profile a step of 10-12 ppm was observed above the lapse rate tropopause between 15.5 and $16 \mathrm{~km}$ and a minimum mixing ratio of $4 \mathrm{ppm}$ at about $17 \mathrm{~km}$. The $\mu$ SDLA profile was also used as a reference for evaluating the measurements of the SAW, of a RS80 sonde at 15:15 LT and a 

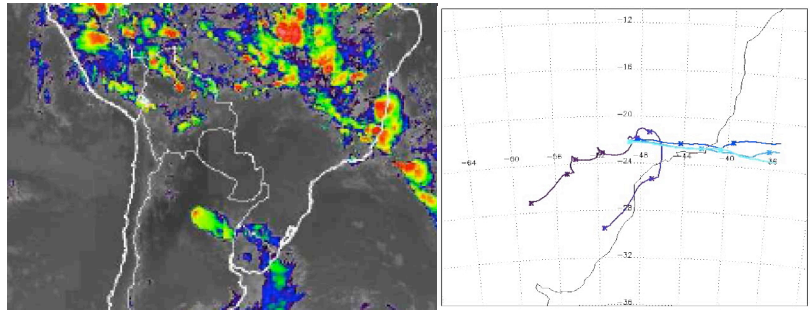

Fig. B4. SF-1 on 16 February. Left: GOES-E image at 19:15 LT. Right BRAMS 4-day backward trajectories at 20:00 LT at $12 \mathrm{~km}$ (black), $14 \mathrm{~km}$ (blue), $16 \mathrm{~km}$ (cyan), $18 \mathrm{~km}$ (green) and $20 \mathrm{~km}$ (yellow).

RS 90 heated-Humicap on the backscatter sonde at 19:35 LT. The RS 80 was found to be significantly dry biased above 6$7 \mathrm{~km}$, the SAW very consistent with the tuneable laser up to $12-13 \mathrm{~km}$, and the RS 90 up to $16 \mathrm{~km}$.

The $\mu$ lidar performed successfully, making a profile of aerosol every $3 \mathrm{~min}$. Unfortunately, because of a failure in one of the battery packs, only the cross-polarized backscattering ratio is available. Cloud layers were seen at around $10-13 \mathrm{~km}$ during the entire flight with a downward slope of $3 \mathrm{~km}$ during the night, corroborated by a backscatter/ozone sonde at 19:35 LT showing two cloud layers between 10 $12 \mathrm{~km}$ and $12.5-13.5 \mathrm{~km}$.

On the same day the first flight of the Falcon took place to the NNE, making a range of observations next to the balloon flight area at the beginning and the end of its flight.

\section{B2.2 SF-1 flight}

This flight was performed within an anticyclonic cloud-free area to the southwest of the SACZ, which had shifted towards north-east (Fig. B4). The balloon was launched at 17:24 LT on 16 February reaching an altitude of $20.5 \mathrm{~km}$ at sunset followed by a $6 \mathrm{~h}$ very slow descent to the $\mathrm{SW}$, where it was cut down at $15.8 \mathrm{~km}$ close to the border of the State of Parana. Four-day trajectory data from RAMS show that at $350-140 \mathrm{hPa}$ in the UT air flowed from the west, around the upper-level Bolivian high, with some descent from slightly higher potential temperature layers (Fig. B5, right), turning to the south at $90 \mathrm{hpa}$ and then towards east above. The radiosonde shows a dynamical tropopause at about $13.5 \mathrm{~km}$ and a thermal tropopause of $-76.1^{\circ} \mathrm{C}$ at $17.5 \mathrm{~km}(84.4 \mathrm{hPa}$, 399 K).

DESCARTES made 6 samplings during the ascent providing reliable data showing a layer of high halocarbon mixing ratio at $8.5-9.5 \mathrm{~km}$, possibly resulting from a transport of urban polluted layer during preceding days. Unfortunately it failed again during the slow descent. LABS and the backscatter sonde did not reported any cloud in the upper troposphere, but only at $3.5-4 \mathrm{~km}$. Ozone data are available from both the SSS and the ECC sonde, showing an ozonopause at $14.6 \mathrm{~km}$.

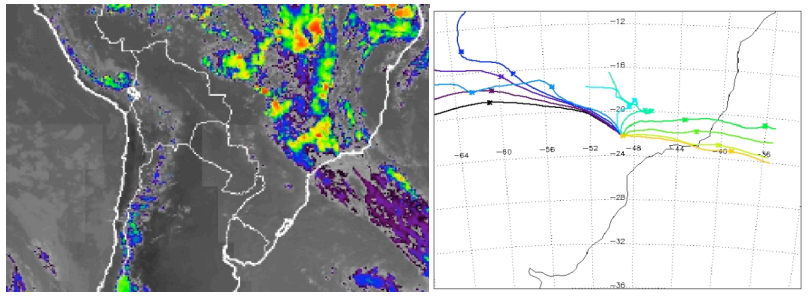

Fig. B5. SF-4 flight on 24 February. Left GOES-E image at 18:15 LT. Right RAMS 5-day backward trajectories at 17:00 LT at $12 \mathrm{~km}$ (black), $14 \mathrm{~km}$ (blue), $16 \mathrm{~km}$ (cyan), $18 \mathrm{~km}$ (green) and $20 \mathrm{~km}$ (yellow).

The TDL made $\mathrm{H}_{2} \mathrm{O}$ measurements during the ascent up to $250 \mathrm{hPa}$, but not above after a drift of the optical alignment. During this flight good data on both electric field and conductivity measurements were obtained. In particular, a complete profile of the electric conductivity due to positive charges was obtained over practically the whole altitude range with measurements every $8 \mathrm{~min}$. A noticeable enhancement of conductivity is observed between 1 and $4 \mathrm{~km}$, while a decrease is observed above at the altitude where the backscattersonde flown $2 \mathrm{~h}$ later showed the presence of thick cloud up to $14.5 \mathrm{~km}$, which may change the nature of the atmospheric ions and modify the electrical parameters of the atmosphere. However, in absence of complementary measurements it is not possible to ascertain such an interpretation.

Cooperative observations are available from the third flight of the Falcon completing two ascent/descent cycles in an area close to the balloon flight track, showing a layer of enhanced $\mathrm{CO}$ at $8-10 \mathrm{~km}$, indicative of urban pollution in coincidence with the halocarbon enhanced layer reported by DESCARTES.

\section{B2.3 SF-4 flight}

This third slow descent flight was launched at 17:03 LT on 24 February when the SACZ was back over the central State of São Paulo (Fig. B6), creating a period of extensive instability with convective activity during day and night, albeit with reduced intensity. The balloon reached an altitude of $20.2 \mathrm{~km}$ shortly before sunset, followed by a 3-h slow descent down to $10.7 \mathrm{~km}$, when it was cut down.

A large area of instability, with more or less randomly developing intense cells was first observed by IPMet's radars in the far north-west of the State of São Paulo, expanding eastwards while moving towards south-east as a whole. Significant intensification occurred from noon onwards, resulting in a massive multi-cellular complex heading towards Bauru during the late afternoon. Cloud tops during the early afternoon were mostly $<14 \mathrm{~km}$, but a few cells penetrated through the tropopause. However, the cloud tops subsided quickly to $<10 \mathrm{~km}$ after sunset. At the time of the launch, the storm 


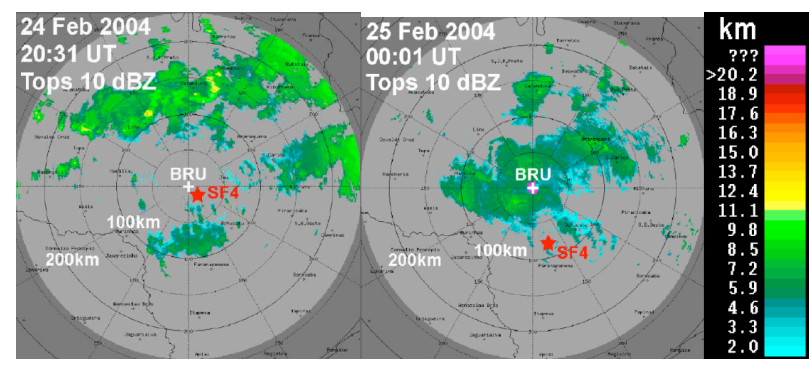

Fig. B6. Echo tops (reflectivity threshold $10 \mathrm{dBZ}$ ) seen by the SBand radar at Bauru (BRU) during the SF4 flight on 24 February 2004. The star represents the balloon location at the time of the radar image. Left: about $30 \mathrm{~min}$ after launch; Right: about $4 \mathrm{~h}$ after launch, towards the end of its float.

complex was about $120 \mathrm{~km}$ to the north-west, moving at $40 \mathrm{~km} \mathrm{~h}^{-1}$ south-eastwards and reaching Bauru shortly after 20:00 LT. Figure B6 shows the radar echo tops detected half an hour after launch and towards the end of its float. The rain area situated 50-100 km south of Bauru (Fig. B6, right) was already in the decaying stage at the time of the launch and never affected the balloon track. Observations performed during this flight are thus representative of the TTL ahead of the approaching mesoscale system, within a generally very convective environment. A radiosonde launched $20 \mathrm{~min}$ after the balloon indicates a secondary tropopause (lapse rate discontinuity) at about $14 \mathrm{~km}$, a minimum temperature of $-78.7^{\circ} \mathrm{C}$ at $15.9 \mathrm{~km}(112 \mathrm{hPa}, 364 \mathrm{~K})$, overlaid by a broad isothermal layer up to $18 \mathrm{~km}(77.5 \mathrm{hPa}, 405 \mathrm{~K})$.

The balloon was carrying six instruments: $\mu$ DIRAC GC, $\mu$ lidar, $\mu$ SDLA, a SAW hygrometer, an $\mathrm{O}_{3}$ SSS and the AIRS electric field sensor. All performed satisfactorily. CFC 11 measurements by the $\mu$ DIRAC show a constant mixing ratio (MR) up to $16 \mathrm{~km}$, followed by a drop off beginning at $17 \mathrm{~km}$. The SSS ozone sensor performed without problems, displaying, in agreement with the ozonesonde flown in parallel, an ozonopause at $14.2 \mathrm{~km}$ and significant structures above. The $\mu$ SDLA shows a very dry layer between $8-11 \mathrm{~km}$, followed by near saturation up to a drop off at $14.8 \mathrm{~km}$ above the secondary tropopause, and a mixing ratio of $4-5 \mathrm{ppm}$ in the TTL. The SAW hygrometer produced good data up to $14 \mathrm{~km}$ during ascent and below $13.5 \mathrm{~km}$ during descent, but showed insufficient sensitivity to make reliable measurements above these heights. During the descent, the $\mu$ lidar made excellent measurements of a $1 \mathrm{~km}$ thick cloud layer at $13 \mathrm{~km}$ at the beginning, followed by the appearance of thin layers just above $14 \mathrm{~km}$ and at $13 \mathrm{~km}$ and more substantial clouds below $12 \mathrm{~km}$. The backscatter sonde launched at 19:30 showed a thick opaque cloud up to $13.5 \mathrm{~km}$ at the beginning of the balloon flight. No lightning was detected by AIRS, but significant drops of the electric field probably related to differential charging of the top (negative) and the bottom (positive) of the cloud layers in the lower layers, and enhance-

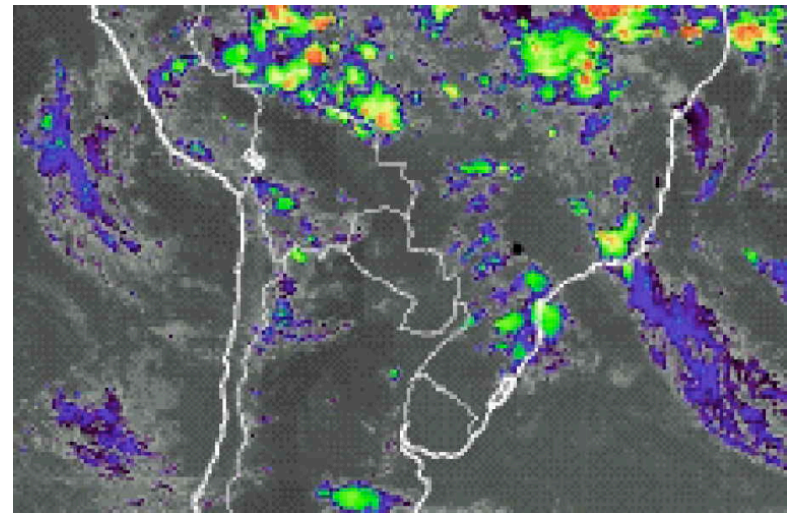

Fig. B7. SF-3 flight on 24 February. GOES-E image at 21:15 LT. Thunderstorms developed over South Brazil in the States of Santa Catarina and Paraná, moving rapidly northwards.

ment of the amplitude of electric field fluctuations near the tropopause where thin cirrus were reported by the backscatter sonde. There was no Falcon or Bandeirante aircraft flight on the day of the SF-4 flight.

\section{B2.4 SF-3 flight}

The last slow descent flight was performed on 26 February. Launched at 17:00 LT, the balloon reached an altitude of $21.6 \mathrm{~km}$ shortly before sunset where it remained for about $1 \mathrm{~h}$ before descending slowly for $03: 45 \mathrm{~h}$ down to $10 \mathrm{~km}$. Very active thunderstorms were developing in the morning over the State of Santa Catarina, moving fast northbound across the State of Parana (Figs. B7 and B8), but faded out by 22:30 LT about $150 \mathrm{~km}$ south-east of Bauru at the end of $\mathrm{SF} 3$. The temperature profiles show a lapse rate tropopause near $15 \mathrm{~km}$, a cold point of $-78^{\circ} \mathrm{C}$ at $80 \mathrm{hPa}$, topped by an almost isothermal TTL up to $18 \mathrm{~km}$.

The SF-3 balloon was carrying a DESCARTES grab sampler, the $\mu$ DIRAC GC, the TDLAS tuneable diode laser, the LABS backscatter diode laser, a SAW hygrometer and an $\mathrm{O}_{3}$ SSS sensor. DESCARTES performed successfully during the ascent and descent, providing measurements of tracers of a large range of lifetime spanning from $50 \mathrm{yr}$ to 3 months. The TDLAS made good measurements both during the ascent and descent. The most notable features of the profile are the low relative humidity (less than 20\%) while ascending up to $15 \mathrm{~km}$, and moist layers (60-80\%) during the descent of the flight (10.5-11.5 km and 13-13.5 km), which are not evident on the ascent, as well as a minimum $\mathrm{H}_{2} \mathrm{O}$ mixing ratio of $2.1 \mathrm{ppm}$ at $17.7 \mathrm{~km}$, around the level of the cold point tropopause. No clouds were observed by LABS during either the ascent or descent, but highly structured layers of depolarizing particles were seen during ascent between 16 and $18 \mathrm{~km}$. 


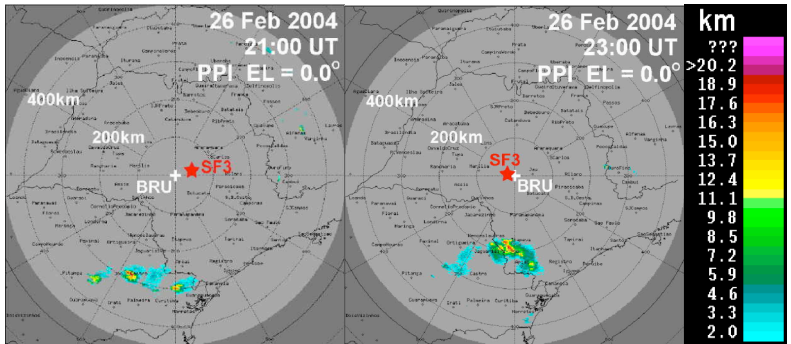

Fig. B8. SF4-flight. Thunderstorms over Paraná approaching from the south, as seen by the Bauru radar at 21:00 and 23:00 UT, respectively; surveillance PPI $(450 \mathrm{~km}$ range $)$ at $0^{\circ}$ elevation. The star represents the SF3 balloon location at the time of the radar image, viz. $1 \mathrm{~h}$ after launch (left) and during its southeastwards float (right), respectively.

Other data available on 27 February are from a Falcon flight from 05:44-08:50 LT), an ozonesonde at 23:35 LT and a MIR SAOZ flight launched at 20:00 providing $\mathrm{O}_{3}, \mathrm{NO}_{2}$, $\mathrm{H}_{2} \mathrm{O}$ profiles on the following morning.

\section{B2.5 Backscatter, ozonesondes and NILUCUBE}

In total $10 \mathrm{BKS} /$ ozonesondes, 3 ozonesondes and 2 NILUCUBE were flown between 10 February and 6 March on $1400 \mathrm{~m}^{3}$ Raven plastic balloons (Table 7). The results of the BKS/ozonesondes are displayed in Fig. B9. On average ozone shows an ozonopause around $13-14 \mathrm{~km}$, very little varying mixing ratio linearly correlated with potential temperature in the lower stratosphere, but significant and frequent variations in the TTL. Cirrus clouds were absent at the beginning during the low convective period between 10 and 17 February but were frequent between 19-23 February at around $13-14 \mathrm{~km}$ when the temperature of the tropopause was cooler. A significant BKS signal was reported on one occasion at an altitude as high as $18-19 \mathrm{~km}$ on 20 February. A $\mathrm{BKS} / \mathrm{O}_{3}$ sonde was always flown in parallel to the SF flights.

The NILUCUBE was flown twice on RAVEN type balloons. The first flight was performed on 13 February under relatively clear sky conditions, but with some bright low-altitude cumulus clouds formed under limited convection conditions. The balloon was launched at 13:00 (UT) and climbed up to about $22 \mathrm{~km}$, followed by a slow descent under a parachute. Solar zenith angles during the flight decreased from about $36^{\circ}$ to $9^{\circ}$. The second flight was on 25 February under overcast conditions with high altitude cirrus. The launch was around local noon at 15:07 (UT). Solar zenith angles increased from about $12^{\circ}$ to $30^{\circ}$ during the flight. The instrument behaved well during both flights. For the flight on 13 February, the radiation increased by about $17 \%$ due to the change in the solar zenith angle between take-off and maximum altitude. On 25 February, the change in the solar zenith angle caused a maximum change of about $4 \%$ in the radiation during the ascent.

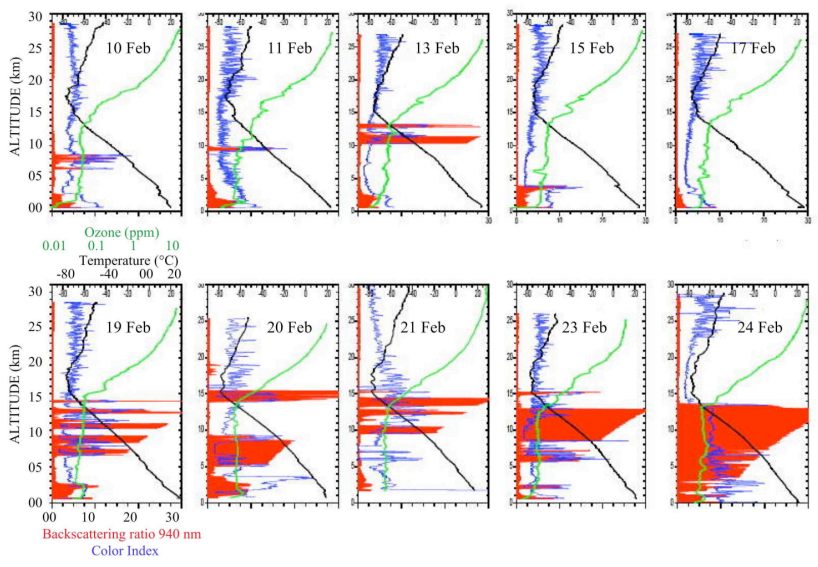

Fig. B9. Ozone mixing ratio (green), backscatter signal (red) and colour index $(940 / 460 \mathrm{~nm})$ of the 10 sondes operated by the Danish Meteorological Institutes between 10 and 24 February.

Acknowledgements. The authors thank the coordinators of TroCCiBras for providing the infrastructure to host HIBISCUS, and the personnel of the Meteorological Research Institute (IPMet) of the São Paulo State University (UNESP), including the students from the Federal University of Rio de Janeiro (UFRJ) and the Center of Laser Applications (CLA) of the University of São Paulo (USP), J. L. Gomes of the Center for Weather Forecast and Climatic Studies (CPTEC), as well as the staff of the Centre National d'Etudes Spatiales (CNES) for their support with weather briefings, balloon, radar, lidar and radiosondes operations. They thank also F. Posny and S. Oltmans for the ozonesondes soundings performed during the MIR overpasses above Reunion Island, Samoa and Fiji and ECMWF and NCAR/NCEP for supplying meteorological data. The HIBISCUS project was supported by the European Commission (contract EVK2-2001-000111), the ENVISAT validation programme of the European Space Agency (project 713), the Programme National de Chimie de l'Atmosphère (PNCA) and the CNES in France, and the Natural Environment Research Council (NERC) in the UK. Computer resources for BRAMS mesoscale modelling were provided by CINES (Centre Informatique National de l'Enseignement Supérieur, project 2227). They are all gratefully acknowledged.

Edited by: R. MacKenzie

\section{References}

Alcala, C. M. and Dessler, A. E.: Observations of deep convection in the tropics using the Tropical Rainfall Measuring Mission (TRMM) precipitation radar, J. Geophys. Res., 107(D24), 4792, doi:10.1029/2002JD002457, 2002.

Adriani, A., Cairo, F., Pulvirenti, L., Cardillo, F., Viterbini, M., Di Donfrancesco, G., and Pommereau, J. P.: Stratospheric background aerosol and polar cloud observations by laser backscattersonde within the framework of the European project "Stratospheric Regular Sounding”, Ann. Geophys., 17, 1352-1360, doi:10.1007/s00585-999-1352-2, 1999. 
Borchi, F. and Pommereau, J.-P.: Evaluation of ozonesondes, HALOE, SAGE II and III, Odin- OSIRIS and -SMR, and ENVISAT-GOMOS, -SCIAMACHY and -MIPAS ozone profiles in the tropics from SAOZ long duration balloon measurements in 2003 and 2004, Atmos. Chem. Phys., 7, 2671-2690, doi:10.5194/acp-7-2671-2007, 2007.

Borchi, F., Pommereau, J.-P., Garnier, A., and Pinharanda, M.: Evaluation of SHADOZ sondes, HALOE and SAGE II ozone profiles at the tropics from SAOZ UV-Vis remote measurements onboard long duration balloons, Atmos. Chem. Phys., 5, 13811397, doi:10.5194/acp-5-1381-2005, 2005.

Borsche, M., Kirchengast, G., and Foelsche, U.: Tropical tropopause climatology as observed with radio occultation measurements from CHAMP compared to ECMWF and NCEP analyses, Geophys. Res. Lett., 34, L03702, doi:10.1029/2006GL027918, 2007.

Buontempo, C., Cairo, F., Di Donfrancesco, G., Morbidini, R., Viterbini, M., Adriani, A.: Optical measurements of atmospheric particles from airborne platform: in-situ and remote sensing instruments for balloons and aircrafts, Ann. Geophys-Italy, 49, 5764, 2006.

Bradshaw, N. G., Vaughan, G., Busen, G., Garcelon, S., Jones, R. L., Gardiner, T., and Hacker, J.: Tracer filamentation generated by small-scale Rossby wave breaking in the lower stratosphere, J. Geophys. Res., 107, doi:10.1029/2002JD002086, 4689, 2002.

Cairo, F., Pommereau, J. P., Law, K. S., Schlager, H., Garnier, A., Fierli, F., Ern, M., Streibel, M., Arabas, S., Borrmann, S., Berthelier, J. J., Blom, C., Christensen, T., D’Amato, F., Di Donfrancesco, G., Deshler, T., Diedhiou, A., Durry, G., Engelsen, O., Goutail, F., Harris, N. R. P., Kerstel, E. R. T., Khaykin, S., Konopka, P., Kylling, A., Larsen, N., Lebel, T., Liu, X., MacKenzie, A. R., Nielsen, J., Oulanowski, A., Parker, D. J., Pelon, J., Polcher, J., Pyle, J. A., Ravegnani, F., Rivière, E. D., Robinson, A. D., Röckmann, T., Schiller, C., Simões, F., Stefanutti, L., Stroh, F., Some, L., Siegmund, P., Sitnikov, N., Vernier, J. P., Volk, C. M., Voigt, C., von Hobe, M., Viciani, S., and Yushkov, V.: An introduction to the SCOUT-AMMA stratospheric aircraft, balloons and sondes campaign in West Africa, August 2006: rationale and roadmap, Atmos. Chem. Phys., 10, 2237-2256, doi:10.5194/acp-10-2237-2010, 2010.

Celarier, E. A, Brinksma, E. J., Gleason, J. F, Veefkind, J. P., Cede, A., Herman, J. R., Ionov, D., Goutail, F., Pommereau, J. P., Lambert, J. C., van Roozendael, M., Pinardin, G., Wittrock, F., Schonhardt, A., Richter, A., Iranhim, O. W., Wagner, T., Bojkov, B., Mount, G., Spinei, E., Chen, C. M., Pongetti, T. J., Sander, S. P., Buesela, E. J., Wenig, M. O., Swart, D. P. J., Volten, H., Kroon, M., Levelt, P. F., Buesela, E. J., Wenig, M. O., Swart, D. P. J., Volten, H., Kroon, M., and Levelt, P. F.: Validation of Ozone Monitoring Instrument nitrogen dioxide columns, J. Geophys. Res., 113, D15S15, doi:10.1029/2007JD008908, 2008.

Chaboureau, J.-P., Cammas, J.-P., Duron, J., Mascart, P. J., Sitnikov, N. M., and Voessing, H.-J.: A numerical study of tropical crosstropopause transport by convective overshoots, Atmos. Chem. Phys., 7, 1731-1740, doi:10.5194/acp-7-1731-2007, 2007.

Chemel, C., Russo, M. R., Pyle, J. A., Sokhi, R. S., and Schiller, C.: Quantifying the imprint of severe Hector thunderstorm during ACTIVE/SCOUT-O3 on the water content in the upper troposphere/lower stratosphere, Mon. Weather Rev., 137, 2493-2514, doi:101175/2008MWR2666.1, 2009.
Christensen, T., Knudsen, B. M., Pommereau, J.-P., Letrenne, G., Hertzog, A., Vial, F., Ovarlez, J., and Piot, M.: Evaluation of ECMWF ERA-40 temperature and wind in the lower tropical stratosphere since 1988 from past long-duration balloon measurements, Atmos. Chem. Phys., 7, 3399-3409, doi:10.5194/acp-7-3399-2007, 2007.

Corti, T., Luo, B. P., de Reus, M., Brunner, D., Cairo, F., Mahoney, M. J., Martucci, G., Matthey, R., Mitev, V., dos Santos, F. H., Schiller, C., Shur, G., Sitnikov, N. M., Spelten, N., Vossing, H. J., Borrmann, S., and Peter, T.: Unprecedented evidence for overshooting convection hydrating the tropical stratosphere, Geophys. Res. Lett., 35, L10810, doi:10.1029/2008GL033641, 2008.

Danielsen, E. F.: A dehydration mechanism for the stratosphere, Geophys. Res. Lett., 9, 605-608, 1982.

Danielsen, E. F.: In situ evidence of rapid, vertical, irreversible transport of lower tropospheric air into the lower stratosphere by convective cloud turrets and by large scale upwelling in tropical cyclones, J. Geophys. Res., 98, 8665-8681, 1993.

Danis, F., Harris, N. R. P., Taylor, W. H., McIntyre, J. D., Simmonds, P. G., and Pyle, J. A.: DESCARTES: A novel lightweight balloon-borne instrument for measurement of halocarbons, Rev. Sci. Instr., 70, 271-280, 2000

Dessler, A. E.: A reexamination of the "stratospheric fountain" hypothesis, Geophys. Res. Lett., 25, 4165-4168, 1998.

Di Donfrancesco, G., Cairo, F., Viterbini, M., Morbidini, R., Buontempo, C., Fierli, F. Cardillo, F., Snels, M., Liberti, G. L., and Di Paola, F.: Cloud and aerosol detection by a balloon borne lidars and backscattersondes in the UTLS during the HIBISCUS campaign: optical and dynamical Properties, Geophysical Research Abstracts, 7, 03355, 2005a.

Di Donfrancesco G., Cairo, F., Held, G., and Fierli, F.: Contemporary measurements of a ground-based weather radar and balloonborne lidar at Bauru during the HIBISCUS Campaigns: A powerful synergy in cloud physics studies, Proc. 32nd Conference on Radar Meteorology, CD, Am. Meteor. Soc., 2005b.

Di Donfrancesco G., Cairo, F., Buontempo, C., Adriani, A., Viterbini, M., Snels, M., Morbidini, R., Piccolo, F. Cardillo, F., Pommereau, J.P., Garnier, A.: Balloon borne lidar for cloud physics studies, Appl. Opt., 45, 5701-5708, 2006.

Dorf, M., Bösch, H., Butz, A., Camy-Peyret, C., Chipperfield, M. P., Engel, A., Goutail, F., Grunow, K., Hendrick, F., Hrechanyy, S., Naujokat, B., Pommereau, J.-P., Van Roozendael, M., Sioris, C., Stroh, F., Weidner, F., and Pfeilsticker, K.: Balloonborne stratospheric $\mathrm{BrO}$ measurements: comparison with Envisat/SCIAMACHY BrO limb profiles, Atmos. Chem. Phys., 6, 2483-2501, doi:10.5194/acp-6-2483-2006, 2006.

Durry, G., Amarouche, N., Zéninari, V., Parvitte, B., Lebarbu, T., and Ovarlez, J.: In situ sensing of the middle atmosphere with balloonborne near-infrared laser diodes, Spectrochimica Acta A, 60(14), 3371-3379, 2004.

Durry, G., Huret, N., Hauchecorne, A., Marecal, V., Pommereau, J.-P., Jones, R. L., Held, G., Larsen, N., and Renard, J.-B.: Isentropic advection and convective lifting of water vapor in the UT - LS as observed over Brazil $\left(22^{\circ} \mathrm{S}\right)$ in February 2004 by in situ high-resolution measurements of $\mathrm{H}_{2} \mathrm{O}, \mathrm{CH}_{4}, \mathrm{O}_{3}$ and temperature, Atmos. Chem. Phys. Discuss., 6, 12469-12501, doi:10.5194/acpd-6-12469-2006, 2006. 
Ebert, E. E. and Holland, G. J.: Observation of record cold cloud-top temperatures in tropical cyclone Hilda (1990), Month. Weather Rev., 120, 2240-2251, 1992.

Fierli, F., Di Donfrancesco, G., Cairo, F., Marécal, V., Zampieri, M., Orlandi, E., and Durry, G.: Variability of cirrus clouds in a convective outflow during the Hibiscus campaign, Atmos. Chem. Phys., 8, 4547-4558, doi:10.5194/acp-8-4547-2008, 2008.

Folkins, I., Loewenstein, M., Podolske, J., Oltmans, S. J., and Profitt, M.: A barrier to vertical mixing at $14 \mathrm{~km}$ in the tropics: Evidence from ozonesondes and aircraft measurements, J. Geophys. Res., 104, 22095-22102, 1999.

Freitas, S. R., Silva Dias, M. A. F., Silva Dias, P. L., Longo, K. M., Artaxo, P., Andreae, M. O., and Fischer, H.: A convective kinematic trajectory technique for low-resolution atmospheric models, J. Geophys. Res., 105(D19), 24375-24386, 2000.

Freitas, S. R., Longo, K. M., Silva Dias, M. A. F., Chatfield, R., Silva Dias, P., Artaxo, P., Andreae, M. O., Grell, G., Rodrigues, L. F., Fazenda, A., and Panetta, J.: The Coupled Aerosol and Tracer Transport model to the Brazilian developments on the Regional Atmospheric Modeling System (CATT-BRAMS) - Part 1: Model description and evaluation, Atmos. Chem. Phys., 9, 28432861, doi:10.5194/acp-9-2843-2009, 2009.

Fueglistaler, S., Dessler, A. E., Dunkerton, T. J., Folkins, I., Fu, Q., and Mote, P. W.: Tropical Tropopause Layer, Rev. Geophys., 47, RG1004, doi:10.1029/2008RG000267, 2009.

Garnier, A., Pommereau, J. P., Cocquerez, P., Letrenne, G., Held, G., and the HIBISCUS team: Impact of tropical convection on UTLS at global scale: the HIBISCUS project, Proc. of the XX Quadrennial Ozone Symposium, edited by: Zerefos, C. S., 1, 1176-1177, 2004.

Garnier, A., Pommereau, J. P., Cocquerez, P., Held, G., and the HIBISCUS team: The balloon flights in the Tropics of the HIBISCUS project, Proc. 17th ESA Symp. Europ. on Rocket \& Balloon, ESA, SP-590, 203-208, 2005.

Gettelman, A., Salby, M. L., and Sassi, F.: Distribution and influence of convection in the tropical tropopause region, J. Geophys. Res., 107(D10), 4080, doi:10.1029/2001JD001048, 2002.

Gettelman, A., Forster, P. M. D., Fujiwara, M., Fu, Q., Vomel, H., Gohar, L. K., Johanson, C., and Ammerman, M.: Radiation balance of the tropical tropopause layer, J. Geophys. Res., 109(D7), D07103, doi:10.1029/2003JD004190, 2004.

Gomes, A. M. and Held, G.: Determinação e avaliação do parâmetro densidade VIL para alerta de tempestades. Proceedings, XIII Congresso Brasileiro de Meteorologia, (CD ROM), Fortaleza, SBMET, 12, 2004.

Gostlow, B., Robinson, A. D., Harris, N. R. P., O'Brien, L. M., Oram, D. E., Mills, G. P., Newton, H. M., Yong, S. E., and A Pyle, J.: Dirac: an autonomous instrument for halocarbon measurements, Atmos. Meas. Tech., 3, 507-521, doi:10.5194/amt-3507-2010, 2010.

Grosvenor, D. P., Choularton, T. W., Coe, H., and Held, G.: A study of the effect of overshooting deep convection on the water content of the TTL and lower stratosphere from Cloud Resolving Model simulations, Atmos. Chem. Phys., 7, 4977-5002, doi:10.5194/acp-7-4977-2007, 2007.

Hanisco, T. F., Moyer, E. J., Weinstock, E. M., St. Clair, J. M., Sayres, D. S., Smith, J. B., Lockwood, R., Anderson, J. G., Dessler, A. E., Keutsch, F. N., Spackman, J. R., Read, W. G., and Bui, T. P.: Observations of deep convective influence on strato- spheric water vapor and its isotopic composition, Geophys. Res. Lett., 34, L04814, doi:10.1029/2006GL027899, 2007.

Hansford, G. M, Freshwater, R. A., Bosch, R. A., Cox, R. A., Jones, R. L., Pratt, K. F. E., and Williams, D. E.: A Low Cost Instrument based on a Solid State Sensor for Balloon-borne Atmospheric $\mathrm{O}_{3}$ Profile Sounding, J. Environ. Monit., 7, 158-162 2005.

Hansford, G. M., Freshwater, R. A., Eden, L., Turnbull, K . F. V., Hadaway, D. E., Ostanin, V. P., and Jones, R. L.: A lightweight dew-/frost-point hygrometer based on a surface acoustic wave sensor for balloon-borne atmospheric water vapour profile sounding, Rev. Sci. Inst., 77, 014502, doi:10.1063/1.2140275, 2006.

Hassim, M. E. E. and Lane, T. P.: A model study on the influence of overshooting convection on TTL water vapour, Atmos. Chem. Phys., 10, 9833-9849, doi:10.5194/acp-10-9833-2010, 2010.

Hauchecorne, A., Godin, S., Marchand, M., Heese, B., and Souprayen, C.: Quantification of the Transport of Chemical Constituents from the Polar Vortex to Middle Latitudes in the Lower Stratosphere using the High-Resolution Advection Model MIMOSA and Effective Diffusivity, J. Geophys. Res., 107(D20), 8289, doi:10.129/2001JD000491, 2002.

Held, G., Calheiros, R. V., and Gomes, A. M.: O Projeto TroCCiBras: Objetivos, Resultados da Campanha 2004 e o Futuro, Boletim da SBMET, 31(1), 81-89, 2007.

Held, G., Pommereau, J. P., and Schumann, U.: TroCCiBras and its partner projects HIBISCUS and TROCCINOX: The 2004 field campaign in the State of São Paulo, Opt. Pura Apl., 41(2), 207216, 2008.

Hendrick, F., Barret, B., Van Roozendael, M., Boesch, H., Butz, A., De Mazière, M., Goutail, F., Hermans, C., Lambert, J.C., Pfeilsticker, K., and Pommereau, J.-P.: Retrieval of nitrogen dioxide stratospheric profiles from ground-based zenith-sky UV-visible observations: validation of the technique through correlative comparisons, Atmos. Chem. Phys., 4, 2091-2106, doi:10.5194/acp-4-2091-2004, 2004.

Hertzog, A., Vial, F., Mechoso, C. R., Basdevant, C., and Cocquerez, P.: Quasi-Lagrangian measurements in the lower stratosphere reveal an energy peak associated with near-inertial waves, Geophys. Res. Lett., 29(8), 1229, doi:10.1029/2001GL014083, 2002.

Hertzog, A., Basdevant, C., and Vial, F.: An assessment of ECMWF and NCEP/NCAR reanalyses in the southern hemisphere at the end of the pre-satellite era: results from the EOLE experiment (1971-1972), Mon. Weath. Rev., 134, 3367-3383, 2006.

Huntrieser, H., Schlager, H., Roiger, A., Lichtenstern, M., Schumann, U., Kurz, C., Brunner, D., Schwierz, C., Richter, A., and Stohl, A.: Lightning-produced $\mathrm{NO}_{\mathrm{x}}$ over Brazil during TROCCINOX: airborne measurements in tropical and subtropical thunderstorms and the importance of mesoscale convective systems, Atmos. Chem. Phys., 7, 2987-3013, doi:10.5194/acp-7-29872007, 2007.

Jégou, F., Urban, J., de La Noë, J., Ricaud, P., Le Flochmoën, E., Murtagh, D. P., Eriksson, P., Jones, A., Petelina, S., Llewellyn, E. J., Lloyd, N. D., Haley, C., Lumpe, J., Randall, C., Bevilacqua, R. M., Catoire, V., Huret, N., Berthet, G., Renard, J. B., Strong, K., Davies, J., Mc Elroy, C. T., Goutail, F., and Pommereau, J. P.: Technical Note: Validation of Odin/SMR limb observations of ozone, comparisons with OSIRIS, POAM III, ground-based and balloon-borne instruments, Atmos. Chem. Phys., 8, 3385- 
3409, doi:10.5194/acp-8-3385-2008, 2008.

Jensen, E. J., Ackerman, A. S., and Smith J. A.: Can overshooting convection dehydrate the tropical tropopause layer?, J. Geophys. Res., 112, D11209, doi:10.1029/2006JD007943, 2007.

Kelly, K. K., Profitt, M. H., Chan, K. R., Loewenstein, M., Podolske, J. R., Strahan, S. ., Wilson, J. C., and Kley, D.: Water vapor and cloud measurements over Darwin during STEP 1987 tropical mission, J. Geophys. Res., 98(D5), 8713-8723, 1993.

Khaykin, S., Pommereau, J.-P., Korshunov, L., Yushkov, V., Nielsen, J., Larsen, N., Christensen, T., Garnier, A., Lukyanov, A., and Williams, E.: Hydration of the lower stratosphere by ice crystal geysers over land convective systems, Atmos. Chem. Phys., 9, 2275-2287, doi:10.5194/acp-9-2275-2009, 2009.

Kistler, R., Collins, W., Saha, S., White, G., Woollen, J., Kalnay, E., Chelliah, M., Ebisuzaki, W., Kanamitsu, M., Kousky, V., van den Dool, H., Jenne, R., and Fiorino, M.: The NCEP-NCAR 50-year reanalysis: Monthly means CD-ROM and documentation, Bull. Am. Meteorol. Soc., 82, 247-267, 2000.

Knollenberg, R. G., Kelly, K., and Wilson, J. C.: Measurements of high number densities ice crystals in the tops of tropical cumulonimbus, J. Geophys. Res., 98(D5), 8639-8664, 1993.

Knudsen, B. M., Christensen, T., Hertzog, A., Deme, A., Vial, F., and Pommereau, J.-P.: Accuracy of analyzed temperatures, winds and trajectories in the Southern Hemisphere tropical and midlatitude stratosphere as compared to long-duration balloon flights, Atmos. Chem. Phys., 6, 5391-5397, doi:10.5194/acp-65391-2006, 2006.

Kylling, A., Danielsen, T., Blumthaler, M., Schreder, J., and Johnsen, B.: Twilight tropospheric and stratospheric photodissociation rates derived from balloon borne radiation measurements, Atmos. Chem. Phys., 3, 377-385, doi:10.5194/acp-3-377-2003, 2003

Lambert, J.-C., Granville, J., Lerot, Hendrick, F., van Roozendael, M., Andersen, S. B., Dorokhov, V., Gerard, P., Gil, M., Goutail, F., Gruzdev, A. N., Held, G., Ionov, D. V., Johnston, P. V., Kostadinov, I., Kreher, K., Kyrö, E., Leveau, J., Navarro-Comas, M., Petritoli, A., Pommereau, J.-P., Richter, A., Roscoe, H. K., Semenov, V. K., Stebel, K., Vaughan, G., Wagner, T., Wittrock, F., and Yela, M.: GDP 4.0 Transfer to SGP 3.0 for SCIAMACHY $\mathrm{NO}_{2}$ column processing: verification with SDOAS/GDOAS prototype algorithms and delta-validation with NDACC/UV-Visible network data, Proc. 3rd workshop on the Atmospheric validation of Envisat, ESA SP-642, 2006.

Lambert, J. C., van Roozendael, M., Andersen, S. B., Burrows, J. P., de Clerq, C., de Semdt, I., Dorokhov, V., Elansky, N. F., Gil, M., Goutail, F., Held, G., Hendrick, F., Hoiskar, B. A. K., Ionov, D. V., Johnston, P. V., Kostadinov, I., Kreher, K., Kyrö, E., Leveau, J., Loyola, D., Müller, J.-F., Petritoli, A., Pinardi, G., Platt, U., Pommereau, J.-P., Puentedura, O., Richter, A., Roscoe, H. K., Semenov, V., Slijkhuis, S., Spurr, R. J. D., Timofeyev, Yu. M., Tornkvist, K. K., Vaughan, G., Wagner, T., Wahl, S., Wittrock, F., and Yela, M.: End-to-End validation of EPS/METOP GOME 2 trace gas data, Proc. First Eumetsat Polar System/MetOp RAO workshop, ESA SP-618, 2007.

Lefèvre, F., Brasseur, G. P., Folkins, I., Smith, A. K., and Simon, P.: Chemistry of the 1991-92 stratospheric winter: threedimensional model simulations, J. Geophys. Res., 99, 81838195, 1994.

Legras, B., Pisso, I., Berthet, G., and Lefèvre, F.: Variability of the Lagrangian turbulent diffusion in the lower stratosphere, Atmos. Chem. Phys., 5, 1605-1622, doi:10.5194/acp-5-1605-2005, 2005.

Levine, J. G., Braesicke, P., Harris, N. R. P., Savage, N. H., and Pyle, J. A.: Pathways and Timescales for Troposphere-to Stratosphere Transport via the Tropical Tropopause Layer and their Relevance for Very Short Lived Substances, J. Geophys. Res., 112, D04308, doi:10.1029/2005JD006940, 2007.

Levine, J. G., Braesicke, P., Harris, N. R. P., and Pyle, J. A.: Seasonal and inter-annual variations in troposphere-to-stratosphere transport from the tropical tropopause layer, Atmos. Chem. Phys., 8, 3689-3703, doi:10.5194/acp-8-3689-2008, 2008.

Liu, C. and Zipser, E. J.: Global distribution of convection penetrating the tropical tropopause, J. Geophys. Res., 110, D23104, doi:10.1029/2005JD006063, 2005.

Marécal, V., Rivière, E. D., Held, G., Cautenet, S., and Freitas, S.: Modelling study of the impact of deep convection on the utls air composition - Part I: Analysis of ozone precursors, Atmos. Chem. Phys., 6, 1567-1584, doi:10.5194/acp-6-1567-2006, 2006.

Marécal, V., Durry, G., Longo, K., Freitas, S., Rivière, E. D., and Pirre, M.: Mesoscale modelling of water vapour in the tropical UTLS: two case studies from the HIBISCUS campaign, Atmos. Chem. Phys., 7, 1471-1489, doi:10.5194/acp-7-1471-2007, 2007.

May, P. T. and Ballinger, A.: The Statistical Characteristics of Convective Cells in a Monsoon Regime (Darwin, Northern Australia), Mon. Weather Rev., 135, 82-92, 2007.

McLinden, C. A., Haley, C. S., Lloyd, N. D., Hendrick, F., Rozanov, A., Sinnhuber, B.-M., Goutail, F. Degenstein, D. A., Llewellyn, E. J., Sioris, C. E., Van Roozendael, M., Pommereau, J. P., Lotz, W., and Burrows, J. P.: Odin/OSIRIS observations of stratospheric BrO: Retrieval methodology, climatology and inferred Bry, J. Geophys. Res., 115, D15308, doi:10.1029/2009JD012488, 2010.

Montoux, N., Hauchecorne, A., Pommereau, J.-P., Lefèvre, F., Durry, G., Jones, R. L., Rozanov, A., Dhomse, S., Burrows, J. P., Morel, B., and Bencherif, H.: Evaluation of balloon and satellite water vapour measurements in the Southern tropical and subtropical UTLS during the HIBISCUS campaign, Atmos. Chem. Phys., 9, 5299-5319, doi:10.5194/acp-9-5299-2009, 2009.

Mote, P. W., Dunkerton, T. J., McIntyre, M. E., Ray, E. A., Haynes, P. H., and Russel III, J. M.: Vertical velocity, vertical diffusion and dilution by midlatitude air in the tropical lower stratosphere, J. Geophys. Res., 103, 8651-8666, 1998.

Nesbitt, S. W., Zipzer, E. J., and Cecil, D. J.: A Census of Precipitation Features in the Tropics Using TRMM: Radar, Ice Scattering, and Lightning Observations, J. Climate, 13, 4087-4106, 2000.

Newman, P. A., Harris, N. R. P., Adriani, A., Amanatidis, G., Anderson, J., Braathen, G., Brune, W., Carslaw, K., Craig, M., DeCola, P., Guirlet, M., Hipskind, S., Kurylo, M., Küllmann, H., Larsen, N., Mégie, G., Pommereau, J.-P., Poole, L., Schoeberl, M., Stroh, F., Toon, V., Trepte, C., Van Roozendael, M.: An overview of the SOLVE-THESEO 2000 campaign, J. Geophys. Res., 107(D20), 8259, doi:10.1029/2001JD001303, 2002.

Newell, R. E. and Gould-Stewart, S.: A stratospheric fountain? J. Atmos. Sci., 38, 2789-2796, 1981.

Nielsen, J. K., Larsen, N., Cairo, F., Di Donfrancesco, G., Rosen, J. M., Durry, G., Held, G., and Pommereau, J. P.: Solid particles 
in the tropical lowest stratosphere, Atmos. Chem. Phys., 7, 685695, doi:10.5194/acp-7-685-2007, 2007.

Nowicki, S. M. J. and Merchant, C. J.: Observations of the diurnal and spatial variability of radiative forcing by equatorial deep convective clouds, J. Geophys. Res., 109, D11202, doi:10.1029/2003D004176, 2004.

O’Connor, F. M., Carver, G. D., Savage, N. H., Pyle, J. A., Methven, J., Arnold, S. R., Dewey, K., and Kent, J.: Comparison and visualisation of high-resolution transport modeling with aircraft measurements, Atmos. Sci. Lett., 6, 164-170, doi:10.1002/asl.111, 2005.

Pielke, R. A., Cotton, W. R., Walko, R. L., Trembaek, C. J., Lyons, W. A., Grasso, L. D., Nieholls, M. E., Moran, M. D., Wesley, D. A., Lee, T. J., and Copeland, J. H.: A comprehensive meteorological modelling system-RAMS, Meteorol. Atm., 49, 69-91, 1992.

Pisso, I. and Legras, B.: Turbulent vertical diffusivity in the sub-tropical stratosphere, Atmos. Chem. Phys., 8, 697-707, doi:10.5194/acp-8-697-2008, 2008.

Pommereau, J. P. and Hauchecorne, A.: A new Atmospheric vehicle: The Infra-Red Montgolfier, in: Scientific ballooning, Adv. Space Res., edited by: Riedler, W., Pergamon Press, 55-58, 1979.

Pommereau, J.-P. and Held, G.: Is there a stratospheric fountain?, Atmos. Chem. Phys. Discuss., 7, 8933-8950, doi:10.5194/acpd7-8933-2007, 2007.

Pommereau, J. P. and Piquard, J.: Ozone, Nitrogen dioxide and Aerosol vertical distributions by UV-visible solar occultation from balloons, Geophys. Res. Lett., 21, 1227-1230, 1994.

Pommereau, J. P., Goutail, F., Pundt, I., Pyle, J. A., Danis, F., Hansford, G., Freshwater, R., Robinson, A., Jones, R. L., Harris, N. R. P., Adriani, A., Cairo, F., Pulvurenti, L., Di Donfrancesco, G., Kirkwood, S., Nilson, H., Arvelius, J., Woods, P., Swann, N. R., Howeison, I. H., Garcelon, S., Gardiner, T. D., Deshler T., and Buivan, A.: Small balloons for stratospheric ozone research and satellite validation, Proc. 14th ESA Symp. on European Rocket and Balloon programme, ESA, SP-437, 609-614, 1999.

Pommereau, J. P., Garnier, A., Nunes-Pinharanda, M., Borchi, F., Hauchecorne, A., and Letrenne, G.: Long Duration SAOZ InfraRed Montgolfier flights at the Tropics for the validation of ozone measuring satellites, Proc. 16th ESA Symp. on European Rocket and Balloon programme, ESA SP-530, 445-450, 2003.

Pommereau, J. P., Garnier, A., Borchi, F., and Nunes-Pinharanda, $\mathrm{M}$.: Ozone and $\mathrm{NO}_{2}$ zonal distribution in the tropical UTLS from SAOZ circumnavigating MIR balloon flights: relation to horizontal transport, convection and lightning, in: Proc. XX Quadrennial Ozone Symposium, edited by: Zerefos, C. S., 2, 11841185, 2004.

Pommereau, J. P, Durry, G., Hauchecorne, A., Held, G., Calheiros, R. V., and Yushkov, V.: Early and geophysical validation of MetOp/IASI water vapour measurements in the tropical upper troposphere and lower stratosphere, Proc. 1st ESA-EUMETSAT EPS/MetOP RAO workshop, ESA SP-618, 2006.

Popp, P. J., Marcy, T. P., Jensen, E. J., Kärcher, B., Fahey, D. W., Gao, R. S., Thompson, T. L., Rosenlof, K. H., Richard, E. C., Herman, R. L., Weinstock, E. M., Smith, J. B., May, R. D., Vömel, H., Wilson, J. C., Heymsfield, A. J., Mahoney, M. J., and Thompson, A. M.: The observation of nitric acid-containing particles in the tropical lower stratosphere, Atmos. Chem. Phys.,
6, 601-611, doi:10.5194/acp-6-601-2006, 2006.

Pundt, I., Pommereau, J. P., Chipperfield, M. P., Van Roozendael, M., and Goutail, F.: Climatology of the stratospheric BrO vertical distribution by balloon-borne UV-Vis spectrometry, J. Geophys. Res., 107, 4806, doi:10.1029/2002JD002230, 2002.

Rabier, F., Järvinen, H., Klinker, E., Mahfouf, J.-F., and Simmons, A.: The ECMWF operational implementation of four dimensional variation assimilation I: Experimental results with simplified physics, Q. J. Roy. Meteorol. Soc., 126, 1143-1170, 2000.

Randel, W. J., Wu, F., and Gaffen, D. J.: Interannual variability of the tropical tropopause derived from radiosonde data and NCEP reanalyses, J. Geophys. Res., 105(D12), 15509-15523, 2000.

Randel, W. J., Wu, F., Oltmans, S. J., Rosenlof, K., and Nedoluha, G. E.: Interannual Changes of Stratospheric Water Vapor and Correlations with Tropical Tropopause Temperatures, J. Atmos., Sci., 61, 2133-2148, 2004.

Ricaud, P., Barret, B., Attié, J.-L., Motte, E., Le Flochmoën, E., Teyssèdre, H., Peuch, V.-H., Livesey, N., Lambert, A., and Pommereau, J.-P.: Impact of land convection on tropospherestratosphere exchange in the tropics, Atmos. Chem. Phys., 7, 5639-5657, doi:10.5194/acp-7-5639-2007, 2007.

Ricaud, P., Pommereau, J.-P., Attié, J.-L., Le Flochmoën, E., El Amraoui, L., Teyssèdre, H., Peuch, V.-H., Feng, W., and Chipperfield, M. P.: Equatorial transport as diagnosed from nitrous oxide variability, Atmos. Chem. Phys., 9, 8173-8188, doi:10.5194/acp-9-8173-2009, 2009.

Rivière, E. D., Pirre, M., Berthet, G., Renard, J.-B., Taupin, F. G., Huret, N., Chartier, M., Knudsen, B. M., and Lefèvre, F.: On the interaction between Nitrogen and Halogen species in the arctic polar vortex during THESEO and THESEO 2000, J. Geophys. Res., 107, 8311, doi:10.1029/2002JD002087, 2003.

Rivière, E. D., Marécal, V., Larsen, N., and Cautenet, S.: Modelling study of the impact of deep convection on the UTLS air composition Part 2: Ozone budget in the TTL, Atmos. Chem. Phys., 6, 1585-1598, doi:10.5194/acp-6-1585-2006, 2006.

Robinson, A. D., McIntyre, J., Harris, N. R. P., Pyle, J. A., Simmonds, P. G. and Danis, F.: A lightweight balloon-borne gas chromatograph for in situ measurements of atmospheric halocarbons, Rev. Sci. Instr., 71, 4553-4560, 2000.

Rozanov, A., Kühl, S., Doicu, A., McLinden, C., Pukite, J., Bovensmann, H., Burrows, J.P., Deutschmann, T., Dorf, M., Goutail, F., Grunow, K., Hendrick, F., von Hobe, M., Hrechanyy, S., Lichtenberg, G., Pfeilsticker, K., Pommereau, J. P., Van Roozendael, M., Stroh, F., and Wagner, T.: BrO vertical distributions from SCIAMACHY limb measurements: comparison of algorithms and retrieval results, Atmos. Meas. Tech. Discuss., 3, 50795178, doi:10.5194/amtd-3-5079-2010, 2010.

Rosen, J. M. and Kjome, N. T.: Backscattersonde: a new instrument for atmospheric aerosol research, Appl. Opt., 30, 1552 1561, 1991.

Seidel, D. J., Ross, R. J., Angell, J. K., and Reid, G. C.: Climatological characteristics of the tropical tropopause as revealed by radiosondes, J. Geophys. Res., 106(D8), 7857-7878, 2001.

Sherwood, S. C. and Dessler, A. E.: On the control of stratospheric humidity, Geophys. Res. Lett., 27(16), 2513-2516, 2000.

Sherwood, S. C., Horinouchi, T., and Zeleznik, H. A.: Convective impact on temperatures observed near the tropical tropopause, J. Atmos. Science, 60, 1847-1856, 2003.

Simmons, A. J. and Gibson, J. K.: The ERA-40 project plan, ERA- 
40 project report series No.1, European Centre for MediumRange Weather Forecasts, Reading, UK, 2000.

Shutts, G. J. and Gray, M.: A numerical modelling study of the geostrophic adjustment process following deep convection, Q. J. Roy. Meteorol. Soc., 126, 823-863, 1994.

Sioris C. E., Kovalenko, L. J., McLinden, C. A., Salawitch, R. J., Van Roozendael, M., Goutail, F., Dorf, M., Pfeilsticker, K., Chance, K., von Savigny, C., Liu, X., Kurosu, T. P., Pommereau, J. P., Bösch, H., and Frerick, J.: Latitudinal and vertical distribution of bromine monoxide and inorganic bromine in the lower stratosphere from SCIAMACHY limb scatter measurements, J. Geophys. Res., 111, D14301, doi:10.1029/2005JD006479, 2006.

Steinwagner, J., Fueglistaler, S., Stiller, G., von Clarmann, T., Kiefer, M., Borsboom, P. P., van Delden, A., and Röckmann, T.: Tropical dehydration processes constrained by the seasonality of stratospheric deuterated water, Nature Geoscience, 3, 262, doi:10.1038/NGEO822, 2010.

Suomi, V. E. and Kuhn, P. M.: An economical net radiometer, Tellus, 10, 161-163, 1958.

Swann, H. A.: Sensitivity to the representation of precipitating ice in CRM simulations of deep convection, Atmos. Res., 47, 415435, 1998

Theys, N., Van Roozendael, M., Hendrick, F., Fayt, C., Hermans, C., Baray, J.-L., Goutail, F., Pommereau, J.-P., and De Mazière, M.: Retrieval of stratospheric and tropospheric BrO columns from multi-axis DOAS measurements at Reunion Island $\left(21^{\circ} \mathrm{S}\right.$, $56^{\circ}$ E), Atmos. Chem. Phys., 7, 4733-4749, doi:10.5194/acp-74733-2007, 2007.

Tuck, A.F., Baumgardner, D., Chan, K. R., Dye, J. E., Elkins, J. W., Hovde, S. J., Kelly, K. K., Loewenstein, M., Margitan, J. J., May, R. D., Podolske, J. R., Proffitt, M. H., Rosenlof', K. H., Smith W. L., Webster, C. R., and Wilson, J. C.: The BrewerDobson circulation in the light of high altitude in situ aircraft, Observations, Q. J. Roy. Meteorol. Soc., 123, 1-69, 1997.

Urban, J., Lautié, N., Flochmoen, E. L., Jiménez, C., Eriksson, P., de La Noe, J., Dupuy, E., Amraoui, L. E., Frisk, U., Jégou, F., Murtagh, D., Olberg, M., Ricaud, P., Camy-Peyret, C., Dufour, G., Payan, S., Huret, N., Pirre, M., Robinson, A. D., Harris, N. R. P., Bremer, H., Kleinbohl, A., Kullmann, K., Kunzi, K., Kuttippurath, J., Ejiri, M. K., Nakajima, H., Sasano, Y., Sugita, T., Yokota, T., Piccolo, C., Raspollini, P., and Ridolfi, M.: Odin/SMR Limb Observations of Stratospheric Trace Gases: Validation of $\mathrm{N}_{2} \mathrm{O}$, J. Geophys. Res., 110, D09301, doi:10.1029/2004JD005394, 2005. van Aalst, M. K., van den Broek, M. M. P., Bregman, A., Brühl, C., Steil, B., Toon, G. C., Garcelon, S., Hansford, G. M., Jones, R. L., Gardiner, T. D., Roelofs, G. J., Lelieveld, J., and Crutzen, P. J.: Trace gas transport in the 1999/2000 Arctic winter: comparison of nudged GCM runs with observations, Atmos. Chem. Phys., 4, 81-93, doi:10.5194/acp-4-81-2004, 2004.

Vernier, J. P., Pommereau, J. P., Garnier, A., Pelon, J., Larsen, N., Nielsen, J., Christensen, T., Thomason, L. W., Leblanc, T., and McDermid, I. S.: Troposphere stratosphere transport in the tropics from CALIOP lidar aerosols measurements, J. Geophys. Res., 114, D00H10, doi:10.1029/2009JD011946, 2009.

Vernier, J. P., Pommereau, J. P., Thomason, L. W., Pelon, J., Garnier, A., Deshler, T., Jumelet, J., and Nielsen, J. K.: Overshooting of clean tropospheric air in the tropical lower stratosphere as seen by the CALIPSO lidar, Atmos. Chem. Phys. Discuss., 11, 163-192, doi:10.5194/acpd-11-163-2011, 2011.

Wetzel, G., Bracher, A., Funke, B., Goutail, F., Hendrick, F., Lambert, J.-C., Mikuteit, S., Piccolo, C., Pirre, M., Bazureau, A., Belotti, C., Blumenstock, T., De Mazière, M., Fischer, H., Huret, N., Ionov, D., López-Puertas, M., Maucher, G., Oelhaf, H., Pommereau, J.-P., Ruhnke, R., Sinnhuber, M., Stiller, G., Van Roozendael, M., and Zhang, G.: Validation of MIPASENVISAT NO2 operational data, Atmos. Chem. Phys., 7, 32613284, doi:10.5194/acp-7-3261-2007, 2007.

Wheeler, M. C. and Hendon, H. H.: An all-season real-time multivariate MJO index: Development of an index for monitoring and prediction, Mon. Weather Rev., 132, 1917-1932, 2004.

Zipser, E. J., Cecil, D., Liu, C., Nesbitt, S., and Yorty, D.: Where are the most intense thunderstorms on earth?, Bull. Am. Meteor Soc., 87, 1057-1071, 2006. 